INSTITUTO DE PESQUISAS ENERGÉTICAS E NUCLEARES

Autarquia associada à Universidade de São Paulo

ESTUDO COMPARADO DAS PERCEPÇÕES DE RISCO NUCLEAR E AMBIENTAL

VERÔNICA ARAUJO BOEMER

Dissertação apresentada como parte dos requisitos para obtenção do Grau de Mestre em Ciências na Área de Tecnologia Nuclear - Materiais.

Orientador:

Prof. Dr. Afonso Rodrigues de Aquino

São Paulo 


\section{DEDICATÓRIA}

À minha mãe Eneide, pelo exemplo de vida e amor.

Ao meu marido Anderson pelo companheirismo, compreensão e apoio.

Aos meus irmãos, Debora e Victor, pelo carinho e amizade. 


\section{AGRADECIMENTOS}

A Deus;

Ao Prof. Dr. Afonso Rodrigues de Aquino pelo incentivo e orientação a este trabalho, pela amizade e paciência. Sou grata pelos momentos de convivência que contribuíram para meu crescimento profissional e pessoal;

À Profa. Dra. Martha Marques Ferreira Vieira, pelas valiosas contribuições e apoio desde o exame de capacidade;

Ao Centro Tecnológico da Marinha em São Paulo (CTMSP), que ao longo dos anos de trabalho me proporcionou os conhecimentos científicos e tecnológicos necessários para o desenvolvimento desta pesquisa;

Ao Instituto de Pesquisas Energéticas e Nucleares (IPEN), pelos conhecimentos adquiridos e pela oportunidade de desenvolver este trabalho;

Aos amigos Paulo César Beltrão de Queiroz e Cíntia Nagako Komatsu, pelo incentivo e apoio no início desta trajetória;

Aos colegas do CTMSP, pela amizade, paciência e compreensão durante o desenvolvimento desta dissertação, em especial às amigas, Eliane Tamanaha de Carvalho e Regiane Inácio, por colaborarem sempre com dedicação;

Às psicólogas e amigas, Tatiana de Sousa Pereira e Camila de Matos Reis Romero, pelo exemplo notório de profissionalismo e pelos momentos imprescindíveis de descontração e diversão;

Aos meus familiares e amigos pelo carinho, paciência e compreensão nas horas de ausência e tensão;

Aos estudantes que colaboraram dedicando parte do seu precioso tempo na resposta ao questionário. Sem a sua participação este trabalho não teria sido realizado;

A todos, muito obrigada! 


\title{
ESTUDO COMPARADO DAS PERCEPÇÕES DE RISCO NUCLEAR E AMBIENTAL
}

\author{
Verônica Araujo Boemer
}

\section{RESUMO}

Com a necessidade de novas formas de produção de energia para conter a crise ambiental e o aquecimento global, novas tecnologias têm sido estudadas e a energia nuclear foi apontada como uma das saídas para a produção de energia limpa. O estudo do risco está diretamente relacionado ao estudo de sua percepção, que determina a maneira de agir do ser humano e, portanto influencia na aplicação de novas tecnologias, uma vez que o reconhecimento de algo como perigoso é determinado por fatores sócio históricos. Este estudo teve como objetivo comparar as percepções de risco nuclear e ambiental, em um grupo de estudantes universitários, com a aplicação de uma pesquisa, no período de 31 de março a 31 de maio de 2010, contendo: imagens de fatos históricos para serem nomeados; estruturação de uma escala de risco para determinadas atividades; e um questionário sobre riscos e benefícios relacionados ao tema da pesquisa. A análise dos resultados evidenciou uma diminuição da percepção do risco nuclear em relação ao risco ambiental na população estudada. 


\title{
A COMPARATIVE STUDY OF THE PERCEPTIONS OF NUCLEAR AND ENVIRONMENTAL RISK
}

\author{
Verônica Araujo Boemer
}

\begin{abstract}
With the necessity for new forms of energy production to contain the environmental crisis and the global warming, new technologies have been studied and the nuclear energy has been placed as one of the ways out for clean energy production. The study of the risk is directly related to the study of its perception, that determines the human being's actions, therefore it influences in new technologies applications, since the awareness of something as dangerous is determined by socio-historical factors. The purpose of this study was compare the perceptions of nuclear and environmental risks, considering a group of university students, with the application of research in the period from March 31 to May 31, 2010, containing: images of historical facts to be nominated; structuring of a risk scale for certain activities, and a questionnaire about risks and benefits related to the subject research. The analysis of results evidenced a reduction in the perception of nuclear risk over the perception of environmental risk in this population.
\end{abstract}




\section{SUMÁRIO}

Página

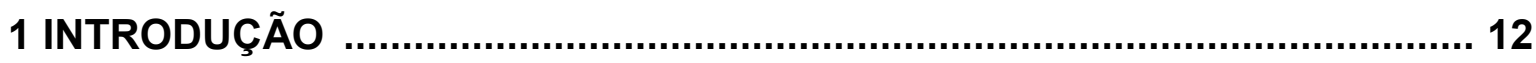

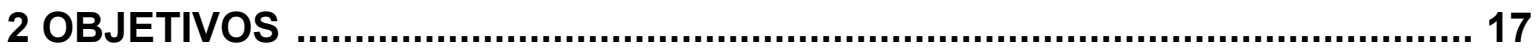

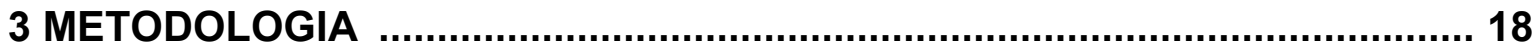

3.1 Estrutura do questionário de pesquisa ……............................................. 18

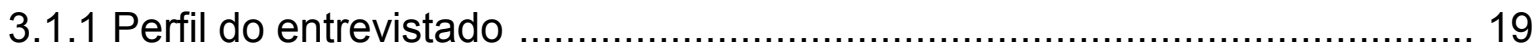

3.1.2 Imagens de fatos históricos ……..................................................... 19

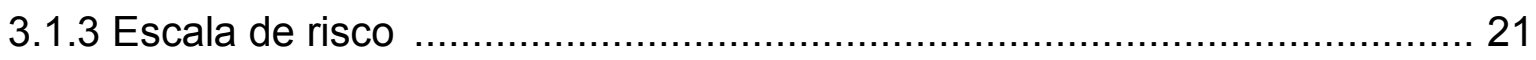

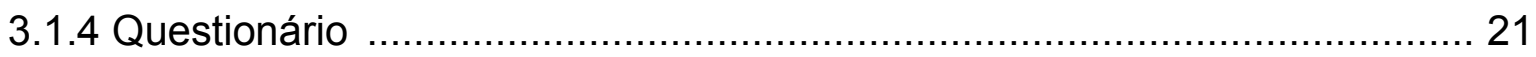

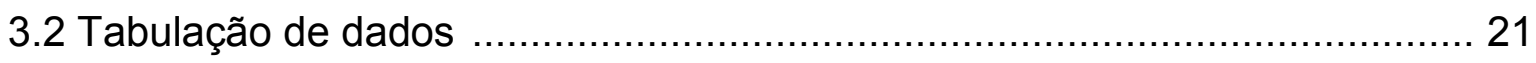

4 AS PERCEPÇÕES DE RISCO NUCLEAR E AMBIENTAL ............................ 22

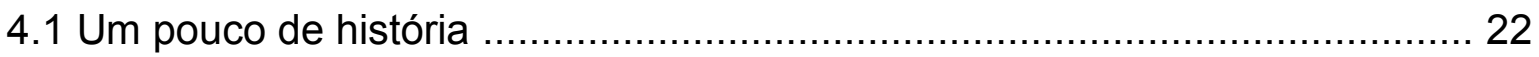

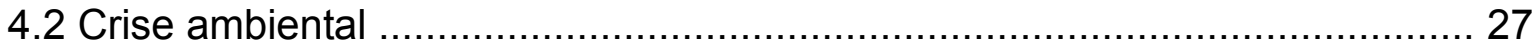

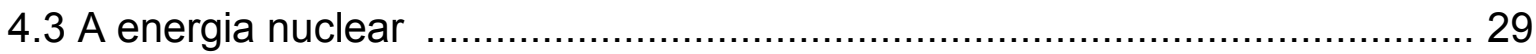

4.4 Definições gerais de risco ...................................................................... 30

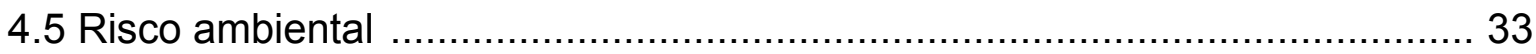

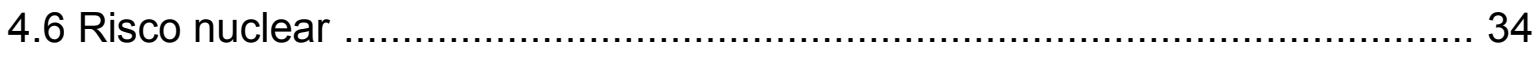

4.7 Percepção de risco ................................................................................ 34

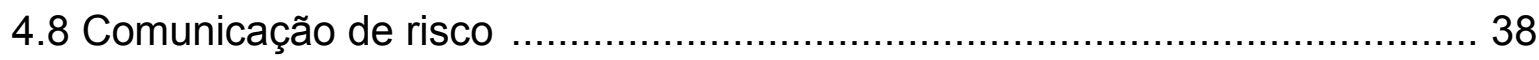

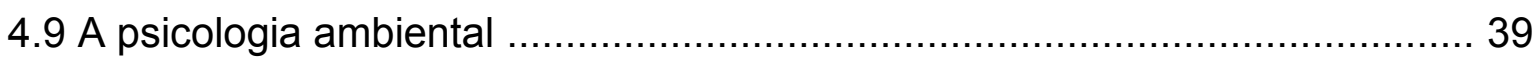

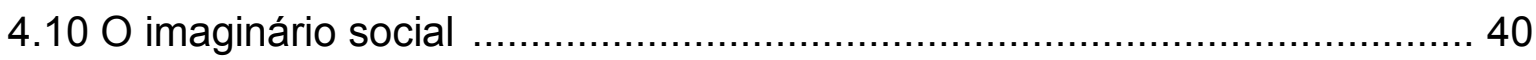




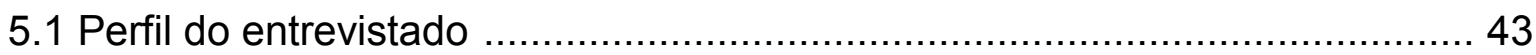

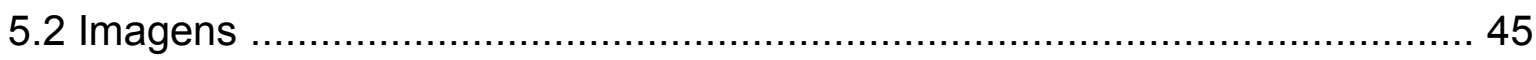

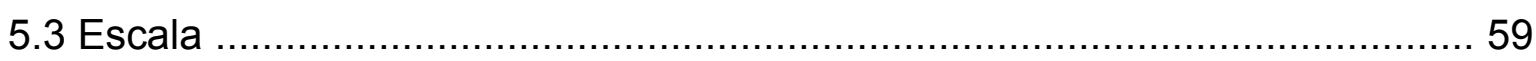

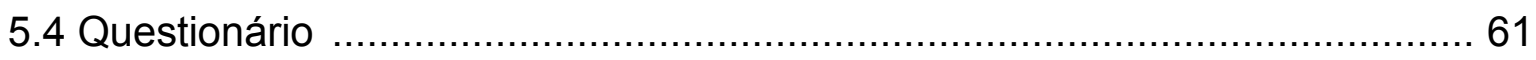

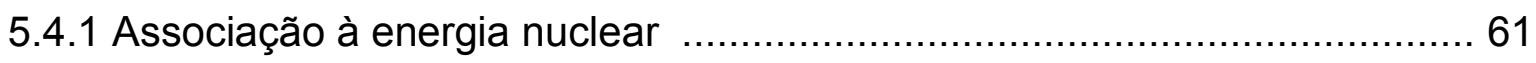

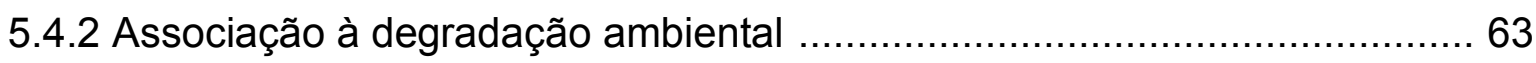

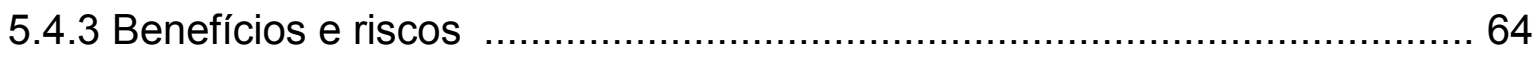

5.4.4 Comparativo entre os riscos: energia nuclear e degradação ambiental ..... 80

5.4.5 Preocupação com o meio ambiente ..................................................... 82

5.4.6 Preocupação com a energia nuclear ..................................................... 83

5.4.7 Pesquisa após o acidente com as usinas nucleares japonesas ................. 85

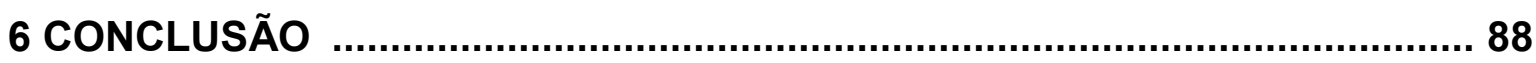

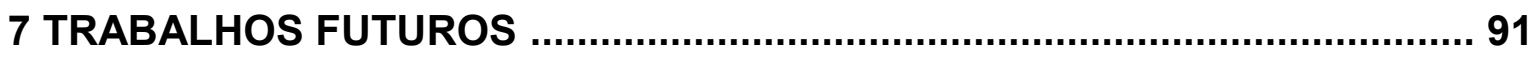

APÊNDICE - Formulário aplicado na pesquisa de campo ........................... 92

REFERÊNCIAS BIBLIOGRÁFICAS ........................................................... 98 


\section{LISTA DE TABELAS}

\section{Página}

TABELA 1 - Principais gases responsáveis pelo efeito estufa 28

TABELA 2 - Comparativo entre termos associados à palavra risco nos anos de 2006, 2009 e 2011

TABELA 3 - Posição em 2009, comparando risco nuclear e ambiental 32

TABELA 4 - Posição em 2011, comparando risco nuclear e ambiental 32

TABELA 5 - Posição em junho de 2011, comparando risco nuclear e ambiental 33 TABELA 6 - Estudantes que responderam à pesquisa, de acordo com faixa etária e sexo

TABELA 7 - Estudantes que responderam à pesquisa, de acordo com estado civil 44

TABELA 8 - Estudantes que responderam à pesquisa, de acordo com a escolaridade e área do conhecimento

TABELA 9 - Estudantes que responderam à pesquisa, de acordo com a universidade e cidade em que estuda

TABELA 10 - Nomeação dada para a FIG. 4 46

TABELA 11 - Sentimento despertado pela FIG. 4 46

TABELA 12 - Nomeação dada para a FIG. 5 48

TABELA 13 - Sentimento despertado pela FIG. 5 48

TABELA 14 - Nomeação dada para a FIG. 6 49

TABELA 15 - Sentimento despertado pela FIG. 6 49

TABELA 16 - Nomeação dada para a FIG. 7 
TABELA 17 - Sentimento despertado pela FIG. 7 50

TABELA 18 - Nomeação dada para a FIG. 8 ………........................................ 52

TABELA 19 - Sentimento despertado pela FIG. 8 …………………............... 53

TABELA 20 - Nomeação dada para a FIG. 9 .................................................... 53

TABELA 21 - Sentimento despertado pela FIG. 9 …...................................... 53

TABELA 22 - Nomeação dada para a FIG. 10 ……....................................... 54

TABELA 23 - Sentimento despertado pela FIG. 10 ......................................... 54

TABELA 24 - Nomeação dada para a FIG. 11 ............................................... 55

TABELA 25 - Sentimento despertado pela FIG. 11 ....................................... 55

TABELA 26 - Nomeação dada para a FIG. 12 …………………………........ 56

TABELA 27 - Sentimento despertado pela FIG. 12 ……............................... 56

TABELA 28 - Escala de risco para determinadas atividades (mais perigoso) .... 60

TABELA 29 - Escala de risco para determinadas atividades (menos perigoso) . 60

TABELA 30 - Postura relacionada ao termo energia nuclear ............................ 62

TABELA 31 - Identificador associado ao termo energia nuclear ....................... 62

TABELA 32 - Postura relacionada ao termo degradação ambiental .................. 63

TABELA 33 - Identificador associado ao termo degradação ambiental .............. 64

TABELA 34 - Benefícios e riscos mais apontados na pesquisa ........................ 80

TABELA 35 - Comparativo entre os riscos da energia nuclear e da degradação

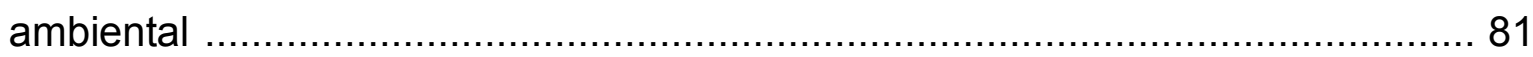

TABELA 36 - Preocupação com o meio ambiente ………………………..... 82

TABELA 37 - Preocupação com a energia nuclear ………………………...... 83

TABELA 38 - Motivação dos que se preocupam igual antigamente .................. 84

TABELA 39 - Motivação dos que se preocupam mais do que antigamente ....... 84

TABELA 40 - Motivação dos que se preocupam menos do que antigamente .... 84

TABELA 41 - Motivação dos que não se preocupam ………............................. 84

TABELA 42 - Pesquisa de opinião: países desfavoráveis ao uso da energia nuclear, antes e depois do acidente com as usinas nucleares japonesas 


\section{LISTA DE FIGURAS}

Página

FIGURA 1 - Concentração da população brasileira ....................................... 24

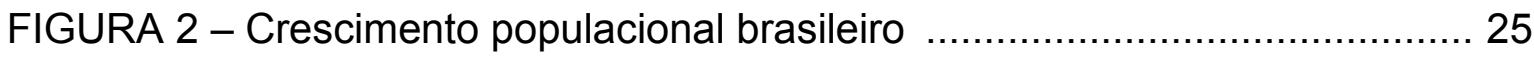

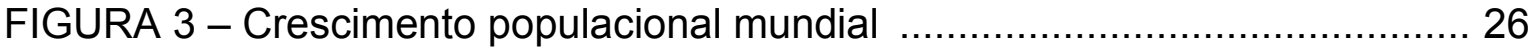

FIGURA 4 - Devastação da Floresta Amazônica ....................................... 46

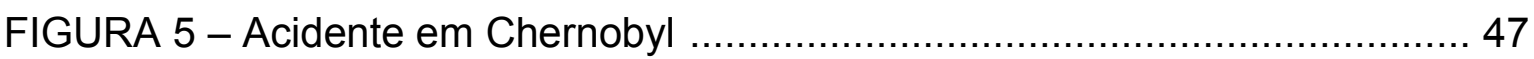

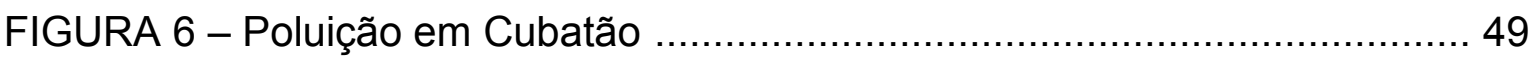

FIGURA 7 - Acidente com o Exxon Valdez ............................................. 50

FIGURA 8 - Acidente em Piper Alpha .................................................. 51

FIGURA 9 - Acidente em Three Mile Island .................................................. 53

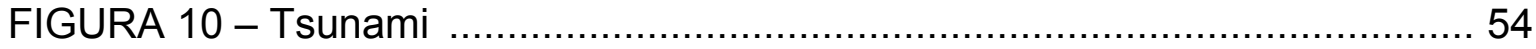

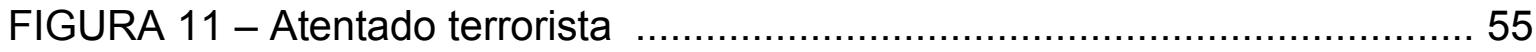

FIGURA 12 - Acidente radiológico de Goiânia ........................................... 56

FIGURA 13 - Sentimentos sobre os eventos do grupo da percepção ambiental 58

FIGURA 14 - Sentimentos sobre os eventos do grupo da percepção nuclear ... 58

FIGURA 15 - Benefícios apontados para a hidroelétrica ............................. 65

FIGURA 16 - Riscos apontados para a hidroelétrica ................................. 66

FIGURA 17 - Benefícios apontados para os veículos automotivos ...................67 67

FIGURA 18 - Riscos apontados para os veículos automotivos ...................... 67

FIGURA 19 - Benefícios apontados para a indústria química $\ldots \ldots \ldots \ldots \ldots \ldots \ldots \ldots . \ldots 6$

FIGURA 20 - Riscos apontados para a indústria química ............................69 69 
FIGURA 21 - Benefícios apontados para novos tratamentos médicos

FIGURA 22 - Riscos apontados para novos tratamentos médicos 71

FIGURA 23 - Benefícios apontados para a termoelétrica 72

FIGURA 24 - Riscos apontados para a termoelétrica 72

FIGURA 25 - Benefícios apontados para o desenvolvimento de novos materiais 73 FIGURA 26 - Riscos apontados para o desenvolvimento de novos materiais .... 74 FIGURA 27 - Benefícios apontados para a radioterapia 75

FIGURA 28 - Riscos apontados para a radioterapia 75

FIGURA 29 - Benefícios apontados para a soja transgênica 76

FIGURA 30 - Riscos apontados para a soja transgênica 77

FIGURA 31 - Benefícios apontados para o reator nuclear de Angra dos Reis ... 78 FIGURA 32 - Riscos apontados para o reator nuclear de Angra dos Reis 79 FIGURA 33 - Pesquisa de opinião sobre o uso da energia nuclear 86 


\section{INTRODUÇÃO}

$\mathrm{Na}$ história das sociedades o risco sempre esteve presente, pois faz parte dos processos de tomada de decisão. Por isso, há muitos anos, busca-se desenvolver formas de minimização dos riscos, estudando e pesquisando desde sua definição até as suas complexas fórmulas estatísticas de avaliação e gerenciamento de risco.

É simples verificar que, todo ser humano, durante sua vida, convive com o risco, e utiliza a avaliação e o gerenciamento deste, pois todos nós convivemos com perigos, sejam eles reais ou percebidos (Molak, 1997).

O estudo de risco quase sempre está relacionado à questão de sua percepção, pois esta determina em muitos momentos a maneira de agir e, portanto influência na aplicação de novas tecnologias. O reconhecimento de algo como perigoso é influenciado pela percepção individual e pelo contexto sócio histórico.

Atualmente, como consequência do crescimento populacional, a demanda por energia e tecnologia tem aumentado e, felizmente, junto com essas necessidades, a preocupação ambiental começa a aparecer em diversos setores da sociedade, especialmente nas indústrias.

Além disso, a população mundial vive em constantes crises, é comum a imprensa noticiar a crise alimentar, a crise do petróleo, a crise energética, entre tantas outras, que influenciam na qualidade de vida dos seres humanos, incitando uma conscientização sobre a contribuição individual para se atingir esta situação e, na mesma direção, incentivando a pensar o que pode ser feito para amenizar tais "crises".

O crescimento econômico foi estimulado desde o fim da Segunda Guerra Mundial até o início da década de 70. O acúmulo de capital foi decisivo, tanto o físico quanto o financeiro e o progresso tecnológico foi marca deste período, este progresso acelerado ficou indiferente à preservação da diversidade ambiental (Guilam, 1996). 
A percepção do risco associada à degradação ambiental é vivenciada de maneira única por cada membro da sociedade. Considerando que, constantemente, o ser humano está envolvido em situações de risco, a população tem sua percepção influenciada pelos diferentes momentos históricos, afetando posturas diante de determinadas ameaças (Della Rocca, 2002).

Há muito tempo a questão ambiental está em discussão, porém, a partir de 1992, o debate se intensificou em virtude da Segunda Conferência Mundial para o Meio Ambiente, que ficou conhecida como Eco-92, realizada no Rio de Janeiro. A Eco-92 deu continuidade à Conferência de Estocolmo de 1972, questionando o futuro do planeta Terra, e qual a postura que o homem deveria assumir. Uma série de importantes documentos foram formulados e, apesar de muitos não terem sido colocados em prática até hoje, ao menos induziram novas discussões e reflexões sobre os temas decorrentes das preocupações ambientais (Nascimento, 2007).

"A Conferência da ONU propiciou um debate e mobilização da comunidade internacional em torno da necessidade de uma urgente mudança de comportamento visando a preservação da vida na Terra." (São Paulo, 1997, p. 17).

A grande repercussão deste encontro nos meios de comunicação propiciou à população em geral tomar conhecimento sobre as condições ambientais mundiais, levando ao público informações a respeito do problema.

$\mathrm{Na}$ ocasião, o problema energético foi um tema muito discutido, especialmente em razão do agravamento das questões climáticas, resultante do aumento no acúmulo de gases responsáveis pelo efeito estufa na atmosfera terrestre. Estudiosos apontaram a tecnologia nuclear como uma saída para a produção de energia limpa, tendo sido considerada por alguns como a forma mais viável para a geração de energia elétrica sem a produção de gases do efeito estufa (Matthes et al., 200-).

Hoje, transcorrido quase vinte anos deste encontro, a discussão ambiental continua em voga na imprensa, no meio acadêmico e no dia-a-dia da população. Por conta disto, a retomada dos estudos e o desenvolvimento da energia nuclear parece importante, não apenas como uma política de estado, mas como uma predisposição da sociedade em participar da preservação do planeta, 
consoante a Constituição da República Federativa do Brasil de $1988^{1}$, em seu artigo 225.

"Todos têm direito ao meio ambiente ecologicamente equilibrado, bem de uso comum do povo e essencial à sadia qualidade de vida, impondo-se ao Poder Público e à coletividade o dever de defendê-lo e preservá-lo para as presentes e futuras gerações." (Brasil, 1988).

A energia nuclear no Brasil começa a tomar novos rumos, devido sobretudo às expectativas de crescimento para a área que apresenta previsões e investimentos, com a aprovação do Plano Nacional de Energia 2030, elaborado pela Empresa de Pesquisas Energéticas (EPE), com aparato do Ministério de Minas e Energia, que por meio de estudos e análises entre o passado, o presente e o futuro traçou um planejamento em longo prazo para o setor energético no país. Neste Plano, são feitas previsões acerca da área, como a construção de seis novas usinas nucleares. Desta maneira, a área ganha um incentivo a mais (Brasil; MME, 2007).

Além da retomada efetiva da construção da usina nuclear de Angra 3 e do anúncio de investimento de recursos para o programa nuclear da Marinha Brasileira, o que deve, em longo prazo, contribuir significativamente para a questão ambiental.

A aprovação do projeto do Reator Multipropósito Brasileiro (RMB), pelo Ministério da Ciência e Tecnologia (MCT), foi conseguida por ser uma solução possível para resolver a crise de produção do Molibdênio-99, ocorrido em 2009.

Outro indício do futuro da energia nuclear no país foi a criação pela Universidade Federal do Rio de Janeiro (UFRJ), do primeiro curso de graduação em engenharia nuclear do país.

Desta forma, o Brasil, após longa estiagem, novamente volta a atenção para o setor nuclear. Porém, a retomada do Programa Nuclear Brasileiro, somente pode ser feita com a anuência da opinião pública, que percebeu a necessidade de se evitar um colapso ambiental. Neste caso, o auxílio dos meios de comunicação foi fundamental, pois a discussão ambiental, diariamente colocada em pauta na imprensa, apontou sobretudo a responsabilidade do

1 Disponível em: <http://www.planalto.gov.br/ccivil_03/Constituicao/Constitui\%C3\%A7ao.htm>. Acesso em: 11 mar. 2008. 
homem sobre a grave situação atingida, e o quanto isso pode significar se algumas providências não forem tomadas.

Deve ser levado em conta que ainda existem resistências que subsistem ao emprego da energia nuclear, que devem ser analisadas a fim de amenizar a postura negativa ante a questão.

Desde a descoberta do potencial destrutivo da energia nuclear a polêmica ronda o seu desenvolvimento. No passado muitas discussões no meio científico dividiram opiniões. Após os acidentes radiológicos, de Goiânia e Chernobyl tais discussões tomaram conta do público em geral. Crucial também para a inflamação da discussão foram os ataques com as bombas atômicas sobre as cidades de Hiroshima e Nagasaki em 1945, que calou o mundo e levou a população a refletir sobre o potencial destrutivo de tal tecnologia, e o quanto esta significava em face das guerras e conflitos entre as nações, pois em mãos erradas poderia ser fatal.

Conforme Camargo (2006) retoma, a história da energia nuclear é repleta de embates entre os próprios cientistas, no que se refere ao uso pacífico da tecnologia nuclear, enquanto uns tentavam conter a replicação da tecnologia, outros defendiam a viabilidade da bomba atômica; muitos participavam dos projetos por pura obrigação e com bastante desconforto.

Após os ataques nucleares à cidades japonesas, a energia nuclear encontrou mais inimigos que lutavam pelo seu fim, pois o medo do holocausto nuclear tomou conta do imaginário social, sobretudo nas proximidades das áreas afetadas, tanto dos ataques das bombas, como no caso dos acidentes em usinas.

Segundo Ponce (2002, p. 97) "existe um campo de significações que aprisiona o discurso pró-nuclear e que o enfraquece por mais que tente falar sobre o lado positivo dessa tecnologia".

O evento ambiental e nuclear mais recente já tem seu lugar reservado na história mundial. O último abalo sísmico ocorrido no Japão, em 11 de março de 2011 teve como consequência um grande tsunami e acidentes nas usinas nucleares com vazamento de radiação, trazendo à tona duas questões fundamentais, a crise ambiental, e a preocupação com o uso da energia nuclear.

Os protestos antinucleares foram rapidamente organizados pelos ativistas, enquanto os especialistas tentavam dar explicações e acalmar a população de outros países detentores da tecnologia nuclear. 
Na mesma intensidade, a questão do aquecimento global e o aumento da probabilidade de ocorrência deste tipo de abalos sísmicos são discutidos em meio ao público em geral.

A Agência Internacional de Energia Atômica (AIEA) acompanha a situação e dia-a-dia atualiza as informações sobre o evento em sua página na Internet, demonstrando que tem acompanhado e auxiliado o governo Japonês (IAEA, 2011).

Este acontecimento deve trazer à ciência incentivo e urgência no tratamento da crise ambiental e do aquecimento global, além de estudos para ampliar o conhecimento científico acerca da segurança nuclear e das definições sobre sua salvaguarda em caso de terremotos e maremotos, além da possibilidade de atualizar as pesquisas relacionadas à percepção destes riscos e à postura social em face destes eventos. 


\section{OBJETIVOS}

Este trabalho teve como objetivo comparar as percepções de risco nuclear e ambiental de um grupo de estudantes universitários (graduação e pósgraduação).

Especificamente:

- Compreender se a questão da preocupação ambiental, caracterizada, sobretudo, pelas mudanças climáticas, como o aquecimento global, tem contribuído para a substituição do medo do holocausto nuclear pelo medo do colapso ambiental, isto é, como a questão ambiental está relacionada com a confiança pública da população urbana brasileira sobre o desenvolvimento e aceitação de novas tecnologias, como a nuclear.

- Averiguar a influência das tragédias ambientais da história sobre o imaginário social, sobretudo no que se refere à postura de aceitação ou não das novas tecnologias e tentativas de amenizar os danos ambientais decorrentes do progresso tecnológico, incitando a discussão acerca de se promover padrões sustentáveis de crenças, valores, atitudes e comportamentos na sociedade, com o intuito de melhorar a relação entre homem e ambiente.

- Compreender a postura social, e a maneira de pensar e responder ao risco, perante a questão ambiental, contribuindo na busca de propostas para solucionar o problema, e entender como o imaginário social influencia as posturas públicas, no que se refere à memória das grandes tragédias ambientais da história, possibilitando uma análise da relativização da percepção de risco, no que tange às áreas nuclear e ambiental.

- Prospectar as primeiras avaliações sobre o acidente ocorrido em março de 2011, com as usinas nucleares japonesas. 


\section{METODOLOGIA}

A metodologia escolhida para o desenvolvimento deste trabalho pode ser dividida em duas partes:

a) Pesquisa bibliográfica - referente à evolução histórica das preocupações ambientais, tanto pelo âmbito nuclear, quanto pelo âmbito ambiental. Para averiguar a influência do imaginário social na postura da população ante o desenvolvimento de novas tecnologias, no que diz respeito à aceitação e compreensão do uso da energia nuclear, bem como à percepção de risco associada, especialmente a fatos do passado. Buscar os resultados das avaliações feitas pela população brasileira identificados em pesquisas de opinião publicadas após o acidente com as usinas nucleares japonesas.

b) Pesquisa de campo - calcada na elaboração e aplicação de um questionário dirigido ao público universitário, com estudantes de graduação e pósgraduação, para comparar sua percepção dos riscos ambientais e nucleares (Apêndice). Foi escolhida essa população, por ter como característica principal a possibilidade de, no futuro, ocuparem posições sociais de formação de opinião. Desta forma, a região de São Paulo foi escolhida por ser a maior e mais representativa do país.

Conforme Gil (2007), uma pesquisa exploratória tem a finalidade de apresentar uma visão geral sobre o tema em questão. Assim, é possível incitar estudos posteriores acerca da influência social nas tomadas de decisão sobre a questão nuclear.

\section{1 Estrutura do questionário de pesquisa}

O questionário (Apêndice) ficou disponível na rede mundial de computadores (Internet), de 31/03/2010 até 31/05/2010, hospedada no link, http://www.medax.com.br/pesquisaacademica.

O formulário disponibilizado é composto por quatro partes, com questões fechadas, semiabertas e abertas, com a seguinte estrutura: 
$1^{\text {a }}$ Parte: Coleta de dados sobre o perfil do entrevistado, tanto demográfico quanto escolar, composto por dez questões;

$2^{\mathrm{a}}$ Parte: Apresentação de nove imagens de fatos históricos para que fossem nomeadas;

$3^{a}$ Parte: Estruturação de uma escala de risco de algumas atividades; e

$4^{a}$ Parte: Questionário com dez questões que atribuem benefícios e riscos relacionados à atividade nuclear e às questões ambientais.

\subsubsection{Perfil do entrevistado}

As perguntas utilizadas para levantamento do perfil demográfico abordam a faixa etária, sexo, estado civil e cidade em que estuda.

Os dados de escolaridade envolveram questões sobre o tipo de curso universitário cursado e o tipo de instituição, se pública ou privada.

\subsubsection{Imagens de fatos históricos}

As imagens foram escolhidas de acordo com fatos passados que marcaram a história, e estão relacionadas a acidentes ambientais e nucleares de grande repercussão.

Com a nomeação das imagens pelo entrevistado avalia-se a memória do fato, ou seja, o quanto as imagens veiculadas na época ainda estão associadas ao evento.

Com a nomeação do sentimento, pareando com a recordação do fato passado, avalia-se a carga emocional que a história ainda representa na memória social.

\section{Imagem 1: Devastação da Floresta Amazônica}

A Floresta Amazônica é degradada desde a época da colonização do território brasileiro, com a extração de minérios, o desmatamento, o crescimento urbano e a extração dos recursos naturais.

\section{Imagem 2: Acidente em Chernobyl}

Ocorrido em 26 de abril de 1986, na Usina Nuclear de Chernobyl na Ucrânia, com uma explosão de vapor no Reator 4, que deslocou a tampa de concreto, seguido de um incêndio, devido às reações químicas. 


\section{Imagem 3: Poluição em Cubatão}

A alta concentração de poluição do município de Cubatão é devida a industrialização acelerada na cidade na década de 80 .

\section{Imagem 4: Acidente com o Exxon Valdez}

Um acidente com o petroleiro Exxon Valdez causou o derramamento de sua carga em 24 de março de 1989, causando danos ao litoral do Alasca.

\section{Imagem 5: Acidente em Piper Alpha}

Em 06 de julho de 1988, ocorreu uma explosão na plataforma petrolífera de Piper Alpha.

\section{Imagem 6: Three Mile Island}

O acidente na usina de Three Mile Island ocorreu em 28 de março de 1979, com uma fusão parcial, ocasionando vazamento de radioatividade para a atmosfera.

\section{Imagem 7: Tsunami}

Um abalo sísmico ocorreu no Oceano Índico em 26 de dezembro de 2004, causando um tsunami, que destruiu zonas costeiras da África, sobretudo em Sumatra.

\section{Imagem 8: Atentado terrorista de 11 de setembro}

Atentado terrorista, ocorrido em 11 de setembro de 2001, ao maior conjunto comercial do mundo, o World Trade Center, em Nova lorque.

\section{Imagem 9: Acidente radiológico de Goiânia}

Em 13 de setembro de 1987, dois catadores de papel, encontraram em um hospital abandonado, um aparelho de radioterapia, que foi destruído e vendido como sucata; com a abertura da cápsula de césio, a contaminação se espalhou. 


\subsubsection{Escala de risco}

A criação da escala de risco permite averiguar a percepção do entrevistado acerca da graduação do risco percebido nas diversas atividades.

\subsubsection{Questionário}

Solicita resposta a questões abertas e fechadas sobre riscos e benefícios nucleares e ambientais, avaliando a percepção dos entrevistados sobre atividades diversas e sua preocupação com as questões acerca do tema.

\section{2 Tabulação dos dados}

Os dados obtidos foram computados e tabulados, expressos em tabelas e gráficos que são apresentados no capítulo de análise dos resultados. 


\section{AS PERCEPÇÕES DE RISCO NUCLEAR E RISCO AMBIENTAL}

\section{1 Um pouco de história}

As percepções e as necessidades podem variar dependendo do local, da sociedade e da época, o que hoje é valorizado como benefício, em outros tempos pode ter sido visto como risco, assim como o que no Brasil é percebido como risco, no Canadá pode ser percebido como benefício. Por isso um levantamento histórico é necessário, para a compreensão de fatos que influenciaram gerações na forma de pensar e agir.

Em 1973, com a primeira crise do petróleo, decorrente da própria criação da Organização dos Países Exportadores de Petróleo (OPEP), os países buscaram alternativas para a geração de energia elétrica em usinas termoelétricas movidas a combustível fóssil. Essa atitude provocou um aumento no número de instalações nucleares que, concomitantemente com a Guerra Fria, serviu para aumentar o medo de um holocausto nuclear, haja vista o poder destrutivo acumulado pelos países ocidentais e do leste europeu. Com a queda do Muro de Berlim e o esfacelamento da União das Repúblicas Socialistas Soviéticas (URSS), em 1989, ocorreu uma diminuição da preocupação com uma grande guerra.

A partir desses fatos, a humanidade em seu conjunto maior, começa a tomar consciência da fragilidade do planeta em termos ambientais. Relatórios, até então restritos ao âmbito político e científico, ganharam as páginas de jornais e revistas de todo o mundo, denunciando a precariedade das condições ambientais na maior parte dos países ditos desenvolvidos.

Assim, de acordo com Nascimento (2007), o resgate do relatório de 1972, do Clube de Roma, intitulado, "Os limites do crescimento", apontava os problemas cruciais para o Planeta em desenvolvimento. Outra publicação importante foi o Relatório de Brundtland, sobre o "Nosso futuro comum", publicado em 1987, enfatizando a necessidade do desenvolvimento sustentável. Ambos os relatórios culminam com a questão do efeito estufa e o consequente agravamento das questões climáticas. 
Além destes relatórios, grandes acidentes ambientais trazem à tona a discussão ambiental, como o ocorrido com o petroleiro Exxon Valdez, no Alaska, em março de 1989, causando grande derramamento de óleo no mar e vitimando milhares de animais.

As atividades nucleares também tiveram sua parcela de contribuição para o aumento da preocupação com as questões ambientais, sobretudo com o acidente na usina nuclear de Chernobyl, em abril de 1986, ocasião em que a explosão do reator quatro gerou uma nuvem radioativa que contaminou parte da Europa.

No Brasil, o acidente radiológico de Goiânia em setembro de 1987, também deixou a população atenta à questão. Neste caso, o furto de um aparelho de radioterapia de um hospital abandonado, ocasionou a contaminação de centenas de pessoas com Césio-137.

Outros poucos acidentes radiológicos aconteceram na história, como o Windscale, na Inglaterra, em outubro de 1957; o de Three Mile Island, nos Estados Unidos, em março de 1979; o de Juarez, no México, em 1983.

Estes acidentes, especialmente o de Chernobyl, considerado o pior da história nuclear mundial, paralisou muitos projetos que estavam em andamento, e cancelou outros. Porém, a partir destes eventos, muitas pesquisas foram desenvolvidas sobre os riscos associados à energia nuclear; tais publicações afetaram diretamente a percepção pública e em muitos países manifestações públicas contra o desenvolvimento do setor e o uso da energia atômica para qualquer finalidade foram realizadas.

Estes fatos auxiliaram a ampliação da percepção negativa dos riscos acerca da radiação, que antes não eram tão grandes, provocando a necessidade de resgatar a confiabilidade do público (Junior Ribeiro, 2007).

No Brasil, após o acidente em Goiânia com o Césio-137, foi possível observar manifestações diversas da população, como reações de rejeição, denúncia, prevenção, fiscalização, discriminação e por fim solidariedade (Chaves, 1993).

O período entre 1986 e 1989, com os acidentes nucleares e ambientais presentes no imaginário social, foi fator chave para a gradativa transferência do temor pelo holocausto nuclear para o temor pelo colapso ambiental. Os meios de comunicação evidenciaram as implicações históricas às quais estes fatos estão 
relacionados, deixando "gravado na memória social que essa tecnologia representa uma ameaça à vida humana na Terra" (Ponce, 2002, p. 12). Com isso, a lembrança cultivada pelo público carrega a veiculação que foi feita sobre as catástrofes nucleares do passado.

A partir de 2006, a consciência coletiva começa a mudar; com a divulgação e o grande empenho da ciência, a população passa a ter conhecimento dos problemas ambientais, cobrando posturas de mudança do Estado e das empresas, influenciando diretamente o mercado.

As necessidades energéticas específicas foram causadas também pela mudança da distribuição da população mundial e do Brasil em particular. Dados dos Censos realizados pelo IBGE, a cada dez anos, como apresentado na FIG. 1, mostram que a migração da população brasileira, das áreas rurais para as áreas urbanas se intensificou desde a década de 1970.

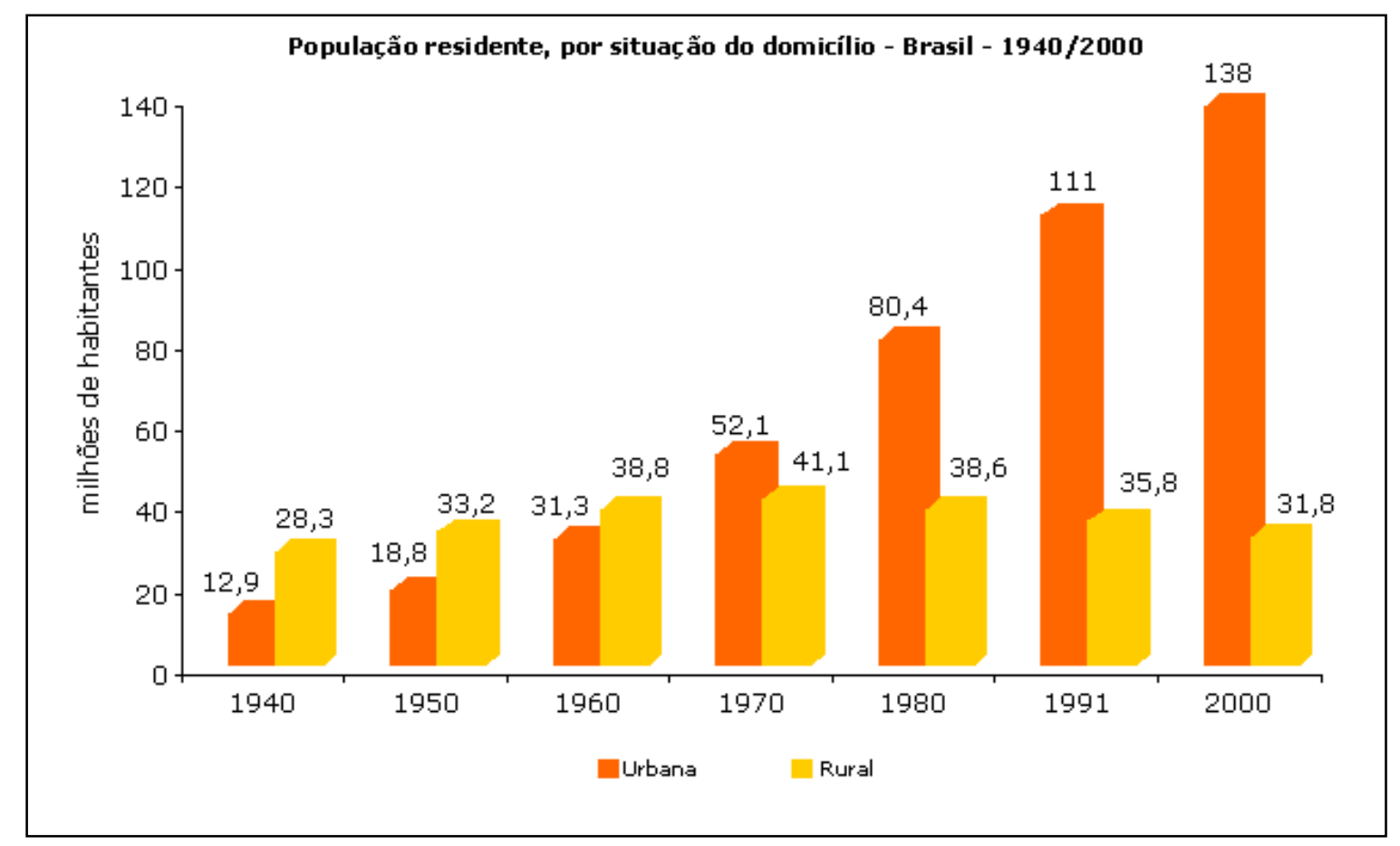

FIGURA 1 - Concentração da população brasileira

Fonte - IBGE

Com isto, verificamos a ocorrência de alguns problemas, como o surgimento da crise alimentar, tendo como agravante o êxodo rural, pois apenas parte dos migrantes possuía agricultura de subsistência, e estes poucos, com a ida para os centros urbanos, passam da condição de micro produtor para a condição de consumidor. 


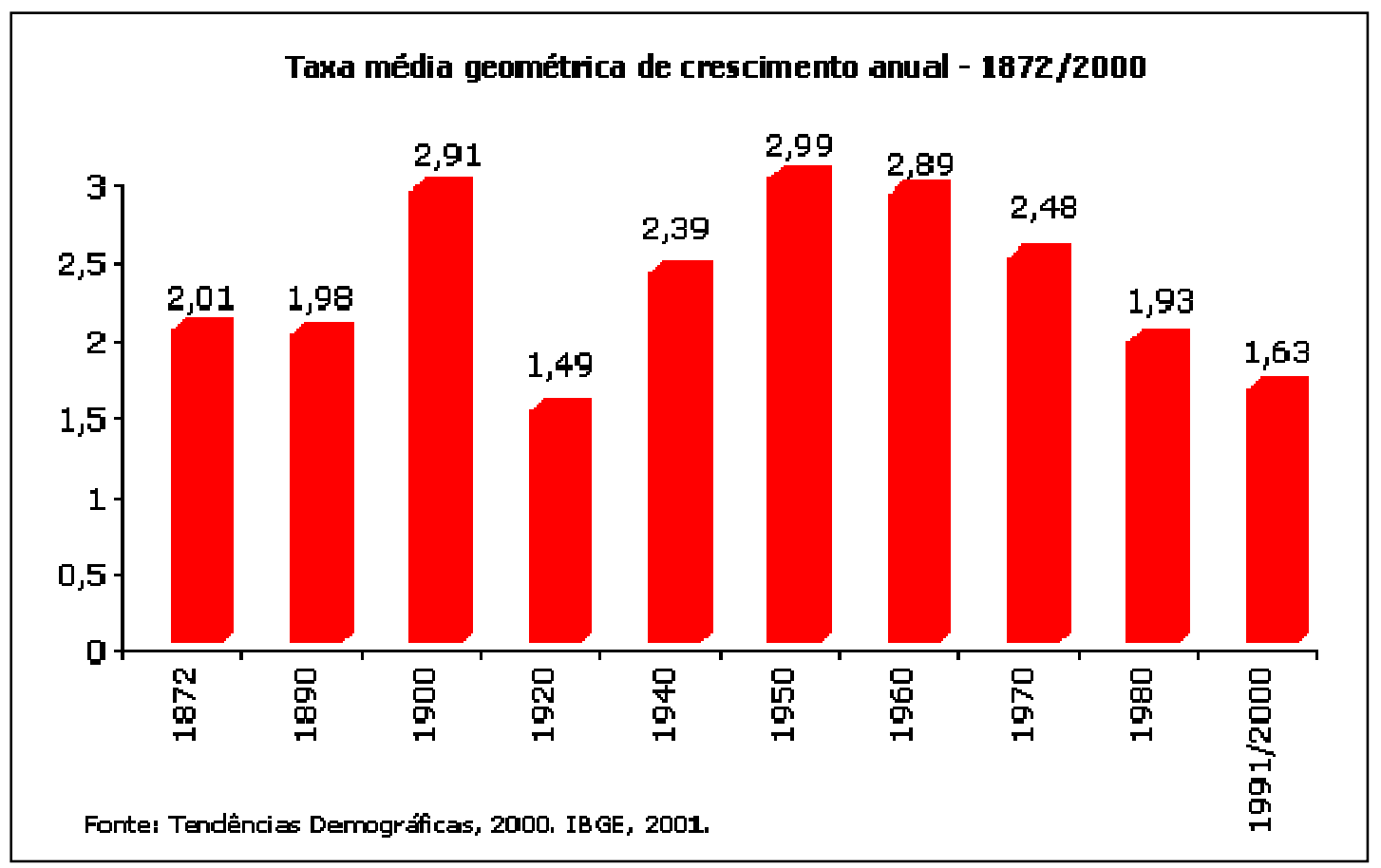

FIGURA 2 - Crescimento populacional brasileiro Fonte - IBGE

Como apresentado na FIG. 2, o crescimento populacional, vem caindo desde a década de 1960; porém, a população se concentra nas áreas urbanas, sobretudo em busca de oportunidades de trabalho e desenvolvimento, o que aumenta a necessidade e consumo de energia, trazendo muitos transtornos para tais localidades.

O crescimento populacional não é apenas tema específico brasileiro, em todo o mundo a densidade populacional tem aumentado de maneira a prejudicar a qualidade da vida humana. Como podemos perceber na FIG. 3, do Population Reference Bureau and United Nations, em 2008 a quantidade de pessoas vivas supera a quantidade de pessoas já falecidas. 


\section{Crescimento Populacional}

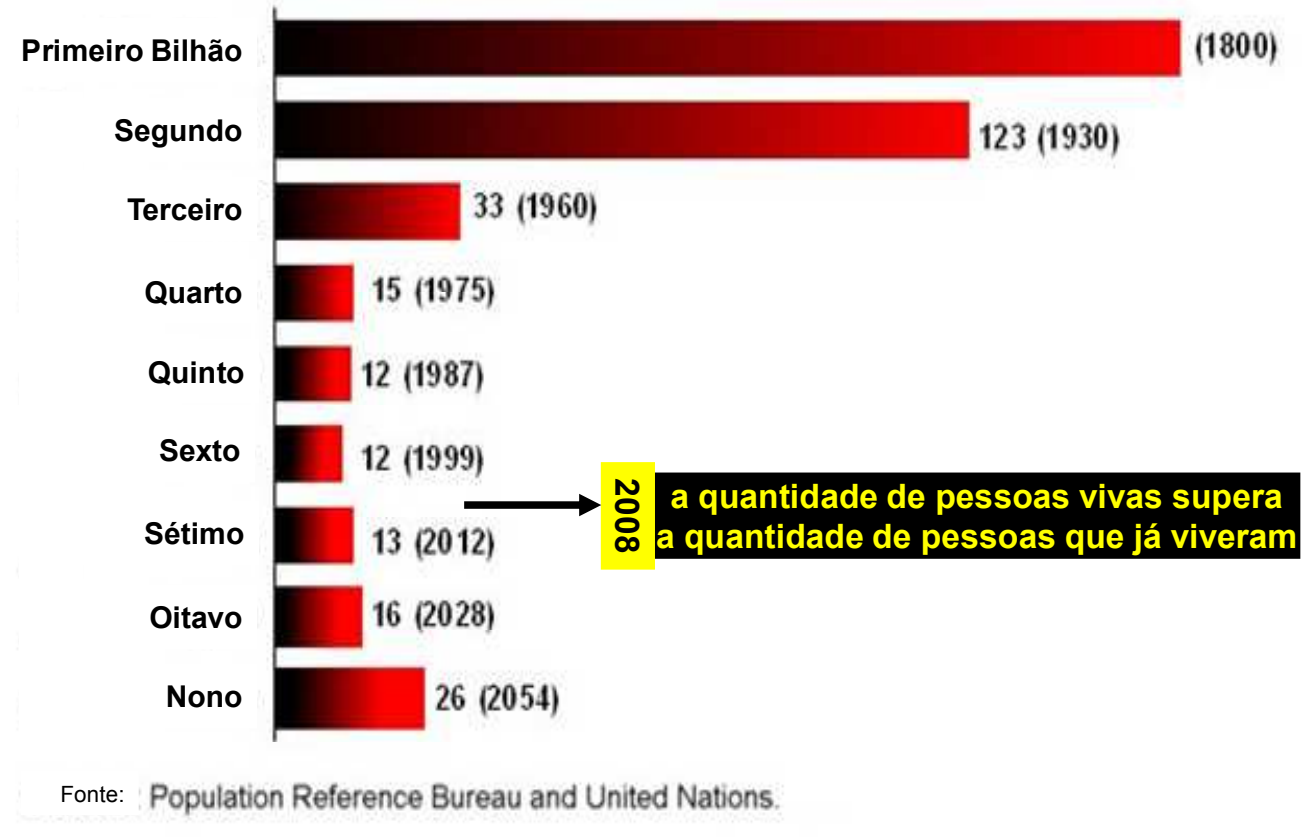

FIGURA 3 - Crescimento populacional mundial

Fonte - Population Reference Bureau

Resultados de estudos sobre percepção de risco têm auxiliado na explicação e previsões e algumas vezes oposição à aceitação de novas tecnologias. Desta maneira, a avaliação, a comunicação e o gerenciamento de risco, são disciplinas que se fazem mais do que necessárias quando se pensa em pesquisa e desenvolvimento de novas tecnologias (Slovic, 2004).

O desenvolvimento conceitual da análise de risco começou nos Estados Unidos e nos países industrialmente desenvolvidos, com o surgimento das usinas nucleares, juntamente com a preocupação sobre a segurança destas instalações e com a criação de agências de proteção à saúde e ao meio ambiente, como Environmental Protection Agency (EPA), Occupational Safety and Health Administration (OSHA), National Institute of Occupation Safety and Health (NIOSH), e outras agências governamentais nos países desenvolvidos, que foram criadas em resposta ao protesto público após a publicação, em 1962, do livro "A Primavera Silenciosa", de Rachel Carson, que explana sobre o uso indiscriminado de agrotóxicos e o aumento da poluição industrial (Molak, 1997).

Durante o século 20, surgiram nas sociedades industriais muitos programas governamentais para avaliar e gerenciar riscos; com isso, muitas 
melhorias foram realizadas em saúde e segurança. Mesmo assim, as pessoas ainda se veem mais vulneráveis aos perigos da tecnologia (Kasperson et al, 2004).

\section{2 Crise ambiental}

O desequilíbrio ecológico do planeta tem o ser humano como o principal responsável, apesar de alguns membros da sociedade ainda manterem certa apatia comportamental perante as questões ambientais. Por isso, é importante ressaltar que a solução está nas mãos humanas. Apesar de existirem sinais positivos com a criação de soluções para determinadas situações, ainda falta colocar em prática ações e políticas públicas, além de incutir na população a importância das ações individuais para o sucesso da tarefa como um todo.

O Quarto Relatório do IPCC 2007 (IPCC-AR4) aponta um aumento médio global das temperaturas entre $1,8^{\circ} \mathrm{C}$ e $4,0^{\circ} \mathrm{C}$ até 2100 , além de apontar com $90 \%$ de confiabilidade que as mudanças climáticas dos últimos 50 anos têm influência das atividades humanas (Avila, 2007).

Desde a década de 1960, alerta-se sobre os efeitos do crescimento econômico nos sistemas ambientais e as discussões acerca da relação homem e ambiente começa a atingir toda a população e os especialistas, e em pouco tempo ganha a popularidade e a preocupação na sociedade.

"Começou a se formar a consciência de que a ação do homem sobre o ambiente está alterando radicalmente os ecossistemas e suas inter-relações, gerando impactos sobre mecanismos globais de sustentação da vida." (Della Rocca, 2002, p. 1).

A Revolução Industrial e o advento do modo de produção capitalista foram cruciais para o progresso da sociedade, acompanhado da degradação ambiental desenfreada, do esgotamento dos recursos naturais e da perda da biodiversidade.

O foco, da crise ambiental, pode ser representado pelo fenômeno do aquecimento global, que se tornou também o grande desafio do século, tanto para a ciência como para o Estado. O tema tem causado muita discussão e preocupação das ações a serem tomadas, com a finalidade de diminuir a emissão 
de $\mathrm{CO}_{2}$, sobretudo originada pela queima de combustível fóssil na produção de energia elétrica.

O efeito estufa é resultante do acúmulo de alguns gases, como o gás carbônico, o metano, os diversos CFC's, dentre outros apontados na TAB. 1, que permitem que a radiação solar ultrapasse a camada da atmosfera e impedem que o calor escape para o espaço, por isso o nome estufa; assim, quanto maior a concentração dos gases maior o aquecimento.

TABELA 1 - Principais gases responsáveis pelo efeito estufa

\begin{tabular}{cc} 
GASES & QUANTIDADE \\
\cline { 2 - 3 } Dióxido de carbono $-\mathrm{CO}_{2}$ & $60 \%$ \\
Metano $-\mathrm{CH}_{4}$ & $20 \%$ \\
Óxido de nitroso $-\mathrm{N}_{2} \mathrm{O}$ & $6 \%$ \\
Halogenados $-\mathrm{HFC}, \mathrm{PFC}$ e SF & $14 \%$ \\
\cline { 2 - 2 } Fonte - São Paulo, Secretaria do Meio Ambiente ${ }^{2}$. &
\end{tabular}

De acordo com Matthes et al (200-), dentre as principais fontes que contribuem para o efeito estufa, as usinas geradoras de energia e calor correspondem a $33 \%$ das emissões de $\mathrm{CO}_{2}$, ou seja, o setor energético tem grande parcela no estado atual do clima mundial, especialmente por causa do uso de combustíveis fósseis.

A melhor solução, além de polêmica, apontada por alguns e criticada por outros, é a utilização da tecnologia nuclear para a produção de energia elétrica em grande quantidade. É importante ressaltar que outras fontes limpas também podem ser usadas, porém, é de conhecimento público que o potencial hidroelétrico e eólico brasileiros, embora grandes, são limitados e suas ocorrências e capacidades de produção regionalizadas e sazonais. As reservas brasileiras de urânio possibilitam a manutenção de um vasto programa de geração de energia durante séculos.

2 Disponível em: <http://homologa.ambiente.sp.gov.br/proclima/efeito_estufa/gases_fontes.asp>. Acesso em: 27 maio 2008. 


\section{3 A energia nuclear}

A descoberta da capacidade do núcleo do átomo de gerar energia somente foi melhor avaliada com o conhecimento de seu poder destrutivo. Isso, na época, provocou diferentes reações na comunidade científica e despertou nos governos a vontade de adquirir o domínio da produção de reatores e bombas nucleares, em busca do aumento dos seus poderios bélicos.

Uma corrida por cientistas capazes de desenvolver tais projetos foi rapidamente iniciada, acirrando os ânimos de países beligerantes.

O descobrimento da energia nuclear, seguida pelos bombardeios a Hiroshima e Nagasaki fez com que sua utilização permanecesse na memória do público firmemente arraigada à guerra e ao horror (Slovic, 1992).

Ao longo dos anos, os acidentes ocorridos com as usinas nucleares tornaram os processos mais cautelosos, resultando na criação de normas para a construção e manutenção dos reatores e seus equipamentos, bem como de qualificação dos seus operadores.

Os ataques nucleares ocorridos em Hiroshima e Nagasaki foram pontuais no que diz respeito à potência das armas atômicas e nas novas posturas das autoridades perante o assunto, e causou reação na opinião pública mundial.

A mídia noticia as ações com a energia nuclear e o controle exercido pela Agência Internacional de Energia Atômica (IAEA - International Atomic Energy Agency), no que se refere às armas nucleares. As notícias mais recentes sobre a energia nuclear têm girado em torno de sua utilização para a produção de energia, com o fim de amenizar os prejuízos da forma de produção tradicional, como forma de controle do aquecimento global, e minimização das consequências das ações do homem sobre o ambiente.

A energia nuclear é vista por alguns, como solução para a produção de energia e consequente diminuição do aquecimento global, por ser considerada uma das fontes mais limpas. Apesar disso, muitos persistem na ideia de que a energia nuclear não deve ser utilizada.

Não é objetivo deste estudo identificar qual forma é mais útil ou mais justa de ser utilizada para geração de energia elétrica, mas sim a postura da população diante da possível solução, ou seja, o quanto as pessoas estão prontas e preparadas para aceitar a produção a partir da energia nuclear, e o quanto podem colaborar para essa decisão. 
Também é de grande importância mostrar ao público os usos possíveis da tecnologia nuclear, como a utilização das radiações em diversas aplicações na medicina, na indústria, na agropecuária e no meio ambiente. A radiação está presente no ambiente, e consequentemente o homem deve estar habituado com os seus benefícios e riscos para a vida cotidiana.

O processo de aceitação de instalação de um complexo nuclear compreende a análise de custo e benefício, ou risco e benefício. Pode-se avaliar que os moradores próximos a tal construção reajam de maneira diferente de pessoas distantes do local de execução do projeto. Os moradores locais levam em consideração questões que envolvem todo o processo, desde seu projeto, construção, fase inicial de funcionamento e período da usina em operação máxima; por isso, sua aceitação envolve diversas razões, simples e complexas, que formam a percepção pública local. Já para o público mais distante da usina, os riscos e benefícios percebidos são mais relevantes quando a usina já estiver em operação, e demonstram questões de ordem mais geral, refletidos nos debates sobre o tema em diferentes canais de comunicação (Slovic, 1992).

Assim, é possível verificar a importância que deve ser dada aos programas de comunicação pública, nesta retomada do Programa Nuclear Brasileiro.

\section{4 Definições gerais de risco}

Segundo Sjöberg e Drottz-Sjöberg (1994) a palavra risco denota, em seu uso cotidiano, uma incerteza associada ao perigo a respeito de um futuro, ou um evento imaginado. Para o senso comum, o termo se associa a fatores que podem diminuir a segurança, o bem-estar, a saúde e a liberdade. Com isso verifica-se o quão ligado está o conceito de risco aos valores humanos.

O Glosario de Términos en Salud Ambiental (1995), da Organização Mundial da Saúde (OMS), define risco como sinônimo de "resposta estimada, probabilidade estimada a priori do efeito, perigo" (p. 65). E acrescenta que o risco para a saúde humana é "a possibilidade (ou probabilidade) de que uma exposição determinada a uma série de exposições, possam causar dano à saúde dos indivíduos submetidos a exposição" (Rodrigues Milord et al, 1995, p. 67).

Bernstein (1997) apresenta a longa trajetória do termo risco, voltando sua visão para as ciências econômicas, mas com importantes apontamentos para 
as diversas ciências, e também para este estudo, como quando apresenta sua origem, citando que "a palavra risco vem do italiano antigo risicare, ou seja, arriscar" (p. VII), acrescentando que também deriva do "baixo latim risicu - riscu." (p. 8).

Della Rocca (2002, p. 1) define risco como "estado de estar ameaçado por algo perigoso".

Enfim, diversas definições de risco são encontradas. Todas trazem a ideia da previsível possibilidade de perigo, com ameaça a alguma pessoa ou a alguma coisa. Assim, como percepção de risco, pode-se entender como o ato de perceber que uma ameaça pode ou não ser prejudicial. E são estas definições que são utilizadas ao longo deste trabalho.

Junior Ribeiro (2007) em sua dissertação apresenta uma consulta ao site Google, em 30 de maio de 2006, associando palavras a risco e verificou que o termo "risco nuclear", perdeu apenas para o risco de drogas. Atualizando esta pesquisa para o período de 2009 e 2011, pode-se verificar o indicado na TAB. 2, mostrado a seguir.

TABELA 2 - Comparativo entre termos associados à palavra risco nos anos de 2006, 2009 e 2011

\begin{tabular}{|c|c|c|c|c|}
\hline Palavra da pesquisa & $\begin{array}{c}\text { Número de } \\
\text { respostas em } \\
30 / 05 / 2006\end{array}$ & $\begin{array}{c}\text { Número de } \\
\text { respostas em } \\
18 / 03 / 2009\end{array}$ & $\begin{array}{c}\text { Número de } \\
\text { respostas em } \\
03 / 03 / 2011^{1}\end{array}$ & $\begin{array}{c}\text { Número de } \\
\text { respostas em } \\
18 / 06 / 2011^{2}\end{array}$ \\
\hline Risco das drogas & 1.730 .000 & 2.740 .000 & 2.170 .000 & 9.160 .000 \\
\hline Risco nuclear & 1.010 .000 & 2.310 .000 & 819.000 & 4.990 .000 \\
\hline Riscos de incêndio & 914.000 & 559.000 & 472.000 & 1.510 .000 \\
\hline Risco rodoviário & 762.000 & 3.060 .000 & 775.000 & 9.290 .000 \\
\hline Risco aéreo & 519.000 & 3.420 .000 & 1.380 .000 & 6.630 .000 \\
\hline Risco marítimo & 453.000 & 2.170 .000 & 1.120 .000 & 4.720 .000 \\
\hline Risco dos agrotóxicos & 317.000 & 129.000 & 209.000 & 839.000 \\
\hline Riscos do fumo & 90.900 & 514.000 & 469.000 & 1.960 .000 \\
\hline Risco ambiental & - & 492.000 & 1.500 .000 & 12.200 .000 \\
\hline
\end{tabular}

1. Uma semana antes do acidente com as usinas nucleares japonesas.

2. Após o acidente com as usinas nucleares japonesas.

Os resultados atualizados para 2009 mostram que os riscos relacionados às palavras, aéreo e rodoviário, superaram o risco das drogas, 
deixando o risco nuclear na quarta posição, o risco das drogas apresentou um aumento de $63 \%$, ao passo que o risco nuclear, apenas $43 \%$. O termo risco ambiental, por estar diretamente relacionado ao tema desta pesquisa foi incluído, apresentando 492.000 respostas em 2009 e 1.500 .000 em 2011 (TAB. 2 e 3).

TABELA 3 - Posição em 2009, comparando risco nuclear e ambiental

\begin{tabular}{llc}
\hline Posição & \multicolumn{1}{c}{ Palavra da pesquisa } & $\begin{array}{c}\text { Número de respostas } \\
\text { em 18/03/2009 }\end{array}$ \\
\hline $1^{\circ}$ & Risco aéreo & 3.420 .000 \\
$2^{\circ}$ & Risco rodoviário & 3.060 .000 \\
$3^{\circ}$ & Risco das drogas & 2.740 .000 \\
$4^{\circ}$ & Risco nuclear & $\mathbf{2 . 3 1 0 . 0 0 0}$ \\
$5^{\circ}$ & Risco marítimo & 2.170 .000 \\
$6^{\circ}$ & Risco de incêndio & 559.000 \\
$7^{\circ}$ & Riscos do fumo & 514.000 \\
$\mathbf{8}^{\circ}$ & Risco ambiental & $\mathbf{4 9 2 . 0 0 0}$ \\
$9^{\circ}$ & Riscos dos agrotóxicos & 129.000 \\
\hline
\end{tabular}

Enquanto os resultados atualizados para 2011 mostram que os riscos relacionados à palavra ambiental superam o risco aéreo e marítimo, deixando o risco nuclear na quinta posição, o risco ambiental apresentou um aumento de $205 \%$, ao passo que o risco nuclear apresentou uma queda de $64,5 \%$, com relação a 2009 (TAB. 4).

TABELA 4 - Posição em 2011, comparando risco nuclear e ambiental

\begin{tabular}{llc}
\hline Posição & Palavra da pesquisa & $\begin{array}{c}\text { Número de respostas } \\
\text { em 03/03/2011 }\end{array}$ \\
\hline $1^{\circ}$ & Risco das drogas & 2.170 .000 \\
$\mathbf{2}^{\mathbf{0}}$ & Risco ambiental & $\mathbf{1 . 5 0 0 . 0 0 0}$ \\
$3^{\circ}$ & Risco aéreo & 1.380 .000 \\
$4^{\circ}$ & Risco marítimo & 1.120 .000 \\
$\mathbf{5}^{\mathbf{0}}$ & Risco nuclear & $\mathbf{8 1 9 . 0 0 0}$ \\
$6^{\circ}$ & Risco rodoviário & 775.000 \\
$7^{\circ}$ & Riscos de incêndio & 472.000 \\
$8^{\circ}$ & Riscos do fumo & 469.000 \\
$9^{\circ}$ & Riscos dos agrotóxicos & 209.000 \\
\hline
\end{tabular}


E os resultados atualizados para junho de 2011, após o acidente ocorrido com as usinas nucleares japonesas aponta que os riscos relacionados à palavra ambiental superou todos os outros riscos, alcançando a primeira colocação com um aumento expressivo de $713 \%$, e o risco nuclear aumentou também de maneira relevante com $509 \%$, permanecendo em quinto lugar (TAB. $5)$.

TABELA 5 - Posição em junho de 2011, comparando risco nuclear e ambiental

\begin{tabular}{llc}
\hline Posição & Palavra da pesquisa & $\begin{array}{c}\text { Número de respostas } \\
\text { em 18/06/2011 }\end{array}$ \\
\hline $\mathbf{1}^{\mathbf{0}}$ & Risco ambiental & $\mathbf{1 2 . 2 0 0 . 0 0}$ \\
$2^{\circ}$ & Risco rodoviário & 9.290 .00 \\
$3^{\circ}$ & Risco das drogas & 9.160 .00 \\
$4^{\circ}$ & Risco aéreo & 6.630 .00 \\
$\mathbf{5}^{\mathbf{0}}$ & Risco nuclear & $\mathbf{4 . 9 9 0 . 0 0 0}$ \\
$6^{\circ}$ & Risco marítimo & 4.720 .000 \\
$7^{\circ}$ & Riscos do fumo & 1.960 .000 \\
$8^{\circ}$ & Riscos de incêndio & 1.510 .000 \\
$9^{\circ}$ & Riscos dos agrotóxicos & 839.000 \\
\hline
\end{tabular}

Diversas disciplinas, em diferentes áreas do conhecimento, têm apresentado estudos e definições do conceito de risco. As ciências sociais focaram no tema da percepção de risco, na perspectiva do indivíduo que percebe as situações de risco, enfatizando em suas pesquisas as influências dos fatores subjetivos (éticos, morais e culturais) nas ações e nas tomadas de decisão (Guilam, 1996).

\section{5 Risco ambiental}

O Glosario de Términos em Salud Ambiental (1995) define risco ambiental, como "a possibilidade de dano, doença ou morte como consequência da exposição do homem a agentes, ou condicionantes ambientais potencialmente perigosas" (Rodrigues Milord et al, 1995, p. 66). 
Desta forma, o risco ambiental está condicionado ao dano associado à exposição, a ações e acontecimentos do ambiente, portanto ligado às ações de degradação ambiental.

\section{6 Risco nuclear}

O risco nuclear está relacionado aos riscos provenientes do desenvolvimento e uso da tecnologia nuclear e eles podem ser físicos, econômicos e estratégicos.

$\mathrm{Na}$ atualidade os riscos que estão envolvidos no uso da tecnologia nuclear, estão voltados para acidentes e possíveis vazamentos nas usinas, além do uso indiscriminado por países que não concordaram com o acordo de não proliferação de armas nucleares (Freire-Maia, 1997).

\section{7 Percepção de risco}

A compreensão da percepção de risco tem recebido contribuições importantes de diversos setores do conhecimento, como da geografia, da sociologia, da ciência política, da antropologia e da psicologia. As pesquisas geográficas contribuíram com o estudo do comportamento humano diante dos riscos naturais, e os estudos antropológicos e sociológicos têm mostrado a influência de fatores sociais e culturais na percepção e aceitação do risco, ao passo que as pesquisas da psicologia se originaram em estudos empíricos dos processos de decisão (Slovic, 2004).

Para Guilam (1996, p. 1), as ciências sociais estudam a percepção de risco, portanto os cientistas sociais "não podem deixar de lado fatores subjetivos (éticos, morais, culturais) que direcionam as opções dos indivíduos".

Segundo Sjöberg e Drottz-Sjöberg (1994), a percepção de riscos é composta por valores e padrões existentes na estrutura cognitiva do indivíduo, estando sobretudo baseada na visão social, no que se refere às questões da globalização. Assim, possui influência direta da cultura, portanto a aceitação ou não de riscos tem forte influência de fatores culturais e sociais.

Guimarães (1999), também apresenta a percepção de risco como um fenômeno vinculado à subjetividade humana. 
"Percepção de riscos: conjunto de fenômenos de natureza sociológica e psicológica que criam uma hierarquia de riscos subjetivos, particular a cada indivíduo e a cada grupo social." (Guimarães, 1999, p. 22).

Os riscos objetivos e os riscos subjetivos devem ser analisados sempre que possível, considerando suas peculiaridades, visto que os riscos subjetivos carregam fatores psicológicos e que "a sociedade tende a subestimar as probabilidades e supervalorizar as gravidades" (Junior Ribeiro, 2007, p. 29).

O desenvolvimento de novas tecnologias está associado a acidentes e falhas. Como a própria história nos mostra, muitos pesquisadores, engenheiros, trabalhadores sofreram graves acidentes, durante os trabalhos; por isso, é preciso levar em consideração que tais acontecimentos levaram ao aperfeiçoamento e a um avanço na segurança, em diversos setores do conhecimento. Porém, a energia nuclear envolve riscos enormes, e portanto não pode utilizar o método da tentativa e erro (Hawkes et al, 1986).

Ao longo do tempo, as fontes percebidas como de risco, foram alteradas, em boa parte por causa dos avanços da ciência, que reduziram ou eliminaram uma série destes. Em contrapartida, tais avanços também trouxeram novos riscos, que estão presentes na vida cotidiana da humanidade. É importante ressaltar que o risco pode ser caracterizado com base em diferentes pontos de vista, ou seja, questões subjetivas estão envolvidas na percepção de risco (Della Rocca, 2002).

No Glosario de Términos em Salud Ambiental (1995), o termo risco aceitável é definido como, "a probabilidade de sofrer enfermidade ou danos que serão tolerados por um indivíduo, grupo ou sociedade". E que seriam influenciados por fatores como informação científica, fatores sociais, econômicos e políticos (Rodrigues Milord et al, 1995, p.66).

Os riscos com características de potencial catastrófico estão frequentemente associados a manifestações de pedido de intervenção dos Governos e autoridades, com a finalidade de regulamentá-los, pois funcionam como uma base importante da percepção de risco (Slovic, 2004).

A percepção de risco associada à tecnologia nuclear e à degradação ambiental faz parte do mundo moderno; porém, fatores diversos influenciam a postura social diante de tais questões, bem como sua aceitação tem acarretado 
mudanças nas ações e atitudes da população, e da ciência, incitando-a a novas descobertas e áreas de pesquisa.

É importante salientar que a consulta prévia à sociedade não é obrigatória, quando da tomada de decisões por governantes. Porém, a sua não realização pode dar vazão a oposição, capaz de colocar por terra qualquer projeto, seja ele nuclear ou de desapropriação de terras, por exemplo, já que as crenças sobre a natureza catastrófica (mesmo com raros eventos na história) da energia nuclear são uma das principais determinantes da oposição pública a essa tecnologia (Slovic et al, 2004).

Segmentos diversos do público podem influenciar na aceitação de novas tecnologias, como a instalação de um reator nuclear, por exemplo, tanto dos que estão diretamente envolvidos como dos que estão distantes. Estes últimos podem desenvolver uma percepção do risco que a instalação representa, pois podem se identificar com aqueles que poderiam ser afetados em caso de algum acidente ou vazamento (Junior Ribeiro, 2007).

As emoções e os sentimentos estão relacionados à percepção de risco e são, portanto, imprescindíveis nas tomadas de decisão. É importante lembrar que as emoções são influenciadas pelas funções cognitivas, pela cultura e pelos valores individuais.

Uma característica que ronda a percepção de risco é o medo, pois as fontes de perigo geram temores ao indivíduo e, portanto reações diversas, variando de pessoa para pessoa, assim como o desconhecimento também pode causar medo e desconforto. Dentre as maneiras de reagir, estão os mecanismos de defesa da psique, como a fuga, a negação, a projeção, o isolamento, a racionalização, entre tantos outros, pois o medo prepara o organismo ou para lutar ou para fugir. Estes mecanismos na maioria das vezes são ineficazes, por isso a comunicação de riscos é um fato importante para a minimização de tais reações públicas.

Quando o perigo não é resultado de um evento natural, e sim da atividade do homem, a formação de grupos opositores é uma das maneiras de se lidar com o desconforto causado pela incerteza do futuro (Sjöberg e DrottzSjöberg, 1994).

Portanto, este estudo irá se centrar na avaliação da percepção do risco perante a população comum, averiguando de que maneira as percepções de risco 
nuclear e ambiental interferem na sua postura diante de tais questões. Visto que, de acordo com Porto (1998), o conceito de risco, ao longo do tempo, foi incorporado por diversas ciências, entre elas as sociais, pois estudos apontam que a análise de riscos não pode estar restrita apenas a uma avaliação quantitativa, pois fatores e valores culturais se misturam na percepção pública.

A teoria homeostática do risco afirma que as pessoas concordam com certo nível de risco proporcionado por uma atividade em troca do benefício que esperam receber (Wilde, 2005).

O risco aceitável é justamente o equilíbrio entre o tamanho do risco, suas consequências e seus benefícios, ou seja, risco pequeno, consequências rápidas, porém com benefícios (reais ou percebidos) grandes, associados à disposição de se submeter a tal risco (Rodrigues Milord et al, 1995).

A análise risco-benefício é encontrada em diversos trabalhos que tratam do assunto de riscos tecnológicos, "a relação entre o risco a que se expõe uma população e o benefício do qual esta mesma população desfruta quando da submissão a determinada tecnologia" (Guilam, 1996).

Assim, podemos compreender que mesmo com muitos acidentes ocorrendo na aviação, por exemplo, a maioria das pessoas, aceita o risco e escolhe o meio de transporte aéreo, pois o benefício, relacionado ao conforto e à rapidez da viagem é comparado com a probabilidade do risco de um acidente, resultando em um nível de risco subjetivamente mais baixo. Assim as pessoas se engajam em ações que podem aumentar sua exposição. Ou seja, um julgamento subjetivo e uma análise comparativa com os benefícios são realizados, para o processo de aceitabilidade do risco (Freire-Maia, 1997).

Nem sempre os riscos que são apontados como prioritários pelas análises estatísticas são identificados como tal pela percepção individual (Guilam, 1996).

O risco percebido e o risco aceito são, portanto, comparados de maneira subjetiva, com a finalidade de direcionar a ação a ser tomada. Essa avaliação é feita por todas as pessoas, em diversas situações e não está vinculada apenas a profissionais ou pesquisadores nos ambientes empresariais ou acadêmicos. Desta forma, uma mudança ou alteração na percepção depende de uma análise e de um balanço entre os riscos e benefícios. Portanto, as 
decisões são influenciadas pelas diferenças individuais e, portanto, algumas pessoas conseguem arriscar mais que outras.

"Se todos avaliassem cada risco exatamente da mesma forma, muitas oportunidades arriscadas seriam perdidas. (...) Onde um vê tempo bom, o outro vê tormenta. Sem o aventureiro, o mundo progrediria bem mais lentamente. Pense em como seria a vida se todos tivessem fobia de raios, de voar de avião e de investir em empresas novas. É realmente uma sorte que os seres humanos difiram em sua atração pelo risco." (Bernstein, 1997, p. 104 e 105).

Estudos realizados por Slovic mostram que a percepção de risco é quantificável e previsível, além de variarem consideravelmente entre a população leiga e especialista (Slovic et al, 2004).

Outro importante ponto apresentado nas pesquisas de Slovic (2004, 1992) indica que os riscos podem se tornar aceitáveis pelo público. A aceitabilidade está diretamente ligada à percepção dos benefícios recebidos, em consequência do risco. Ou seja, o risco pode ser aceito, desde que seja reconhecido um benefício, que para aquela população é considerado importante. Porém, o risco percebido pode depender muito da maneira como a informação é apresentada, por isso, deve-se ter o cuidado necessário na comunicação e apresentação da informação que levará à aceitabilidade do risco. Portanto, redução de risco pode envolver redução de benefícios, o que traz dilemas à sociedade.

Com relação ao crescente desenvolvimento de novas tecnologias, vemos que os responsáveis pela tomada de decisão, são obrigados a equilibrar riscos e benefícios. Com isso tem transformado a análise de risco-benefício, em análise custo-benefício, surgindo uma nova metodologia para a tomada de riscos sociais (Fischhoff et al, 2004).

\section{8 Comunicação de riscos}

A comunicação de riscos deve ser pautada, primeiramente, na divulgação científica, ou seja, na popularização da informação que é técnica, e portanto especializada. "Comunicar ciência também passou a ser educar, 
conscientizar, preparar o cidadão para a vida, disponibilizar informações que o façam conhecer o que se passa a seu redor" (Ponce, 2002, p. 10).

A amplificação social do risco, está diretamente relacionada à forma como são transmitidos os acontecimentos. No processo de comunicação o risco pode ser atenuado ou intensificado, visto que raramente se tem acesso direto ao acontecimento de risco. Quando o público tem conhecimento do fato, geralmente este vem amplificado pelo seu comunicador (rádio, televisão, revistas, amigos, entre outros). Já o ouvinte, por sua vez, amplifica ou atenua a mensagem à sua maneira, e age diante delas de diversas maneiras possíveis (ignora, tolera, aceita, atua, entre outras) (Lima, 2008).

Deve ser levado em consideração o conceito básico de risco do público leigo, pois suas preocupações são legítimas e muito mais ricas do que a dos especialistas, que por vezes podem omitir conceitos importantes, por achar banalizado devido à sua especialização (Slovic, 2004).

\section{9 A psicologia ambiental}

Apesar de existir indícios do uso da psicologia ambiental há algum tempo, só tem sido utilizada em parceria com outras ciências muito recentemente, a partir da década de 60. Pode-se levantar a hipótese de que a atual crise ambiental tenha apresentado a necessidade do amparo da psicologia às outras áreas do conhecimento, em razão do envolvimento do homem para tal situação crítica.

\footnotetext{
"A crise ambiental pode ser vista como uma crise política da razão ante dificuldades em explicar a natureza social do mundo globalizado, histórica e culturalmente determinada." (Tassara, 2004, p. 5).
}

A crise ambiental está vinculada ao modelo de sociedade em que vivemos atualmente, consequentemente ligada à cultura humana; desta maneira compreendemos a importância do vínculo da psicologia com as ciências que estudam as questões ambientais.

Muito já se discutiu acerca das aplicações da psicologia ambiental, um consenso geral, grosso modo, aponta que essa área da psicologia possui como objeto as relações entre o homem e seu meio ambiente. 
“(...) define o objeto da Psicologia Ambiental como a mútua influência de fatores ambientais e comportamentais no enfoque de problemas específicos e de suas soluções." (Corral-Verdugo, 2005, p. 71).

O comportamento humano, como objeto da psicologia, deve ser estudado em sua relação com o meio ambiente, no sentido de sua atuação sobre este, avaliando sua degradação e estudando maneiras de se concretizar o desenvolvimento sustentável, a partir da ação do homem sobre o meio em que se vive.

Segundo Della Rocca (2002), a opinião pública se transformou ao longo dos anos no que se refere ao papel da tecnologia e da modernidade, e os riscos que esta pode trazer ao meio ambiente; com isso, as discussões acerca dos problemas trazidos pelo desenvolvimento começam a ser colocados em pauta.

"Atualmente, observa-se uma postura dúbia do público em relação ao conhecimento científico: a ciência e a tecnologia são consideradas a causa e a solução dos riscos da modernidade." (Della Rocca, 2002, p. 19).

Com isso, verifica-se que as preocupações com o risco advindo do desenvolvimento das ciências e da tecnologia é percebido pelo público como um todo, o que torna possível associar que tais sentimentos estão arraigados no imaginário social da população.

Os diversos grupos sociais podem entender o risco de maneiras diferentes, no que se refere a tecnologia, os grupos distinguem-se entre, especialistas, leigos e público em geral.

\section{100 imaginário social}

O imaginário social é um produto social, pois é criado pelo conjunto de relações que compõem a memória dos grupos no seu convívio social, e consequentemente é passado de geração para geração, sendo influenciado pela situação da sociedade naquele momento histórico específico. Como apontado por 
Ponce (2002, p. 30), "as reflexões humanas produzem reflexos que interferem na existência dos indivíduos enquanto integrantes de uma sociedade".

Desta forma, cria-se um mundo de significações próprio daquela sociedade, que de maneira inconsciente é seguido por todos os seus membros. Sem questionamento as ações vão ocorrendo, e se chega ao ponto de degradação do planeta, neste momento alguns membros começam a racionalizar e conseguem avaliar a situação, incutindo tais questões em outros indivíduos, podendo chegar aos dilemas coletivos, envolvendo um grande número de pessoas em busca da solução para um problema comum, transformando, desta maneira, as angústias individuais em dilemas coletivos (Tassara, 2004).

É importante ressaltar que parte dos constructos constituintes do imaginário social, tem sua origem em questões religiosas, políticas e culturais, podendo ser incutidos por influencia de grupos interessados em conduzir o público a um pensamento comum.

A psicologia possui como objeto de estudo o comportamento e a experiência humana, com base em seus aspectos mentais e sua relação com o ambiente físico e social, que são repletos de significações, com as quais, os sujeitos convivem em constante interação; por isso, são considerados constructos sociais, ou seja, são significados, valores, construídos por meio da interação dos diversos membros do grupo social; dele fazem parte também, a consciência, a cultura ambiental dominante daquela sociedade (Corral-Verdugo, 2005).

A busca pelo sonhado desenvolvimento sustentável deve partir de uma ação social, não basta um único indivíduo se engajar nesta ação, ele necessita do apoio e amparo da sociedade como um todo, por isso um dos caminhos para se chegar a este ponto, é o de incutir no imaginário social a importância de que cada sujeito tenha um comportamento pró-ambiental, ou seja, um comportamento de ação que antes seja analisado do ponto de vista de conservação ambiental (Tassara, 2004).

Desta maneira, o imaginário social é construído em torno daquelas questões que fazem parte da vida da sociedade. A questão nuclear é uma delas: o seu poder destrutivo, descoberto após os bombardeios em Hiroshima e Nagasaki, além dos acidentes em usinas nucleares, foi determinante para incutir a ideia do risco de uma contaminação "invisível", gerando o medo da tecnologia nuclear (Chaves, 1993). 
Da mesma forma, a sensibilização do público para as questões das alterações climáticas, pode ajudar nas mudanças comportamentais das práticas ambientais. A compreensão e o conhecimento dos sentimentos da população devem ser úteis nesta prática.

"Enfatizar a mensagem de que cada um de nós tem
responsabilidade na resolução deste problema e que todos
juntos, somos importantes na mitigação das alterações
climáticas e sua adaptação." (Rodrigues et al, 2009, p.
3426).

Nas diversas situações de ameaça, catástrofes e acidentes, como os acidentes e ataques ocorridos na história, o público está dependente de informação, uma "necessidade social interage com os processos psicológicos, sociais e culturais de forma a acentuar ou a atenuar as percepções de risco." (Lima, 2008, p. 19).

O entendimento e a compreensão da percepção pública acerca do tema podem facilitar e trazer novas formas e métodos de abordagem, para uma melhora ambiental. 


\section{RESULTADOS E DISCUSSÃO}

Ao todo, 235 estudantes responderam ao questionário, que foram numerados automaticamente pelo sistema por ordem de acesso. Após uma avaliação de todos os questionários respondidos, onze foram desconsiderados, pois seis não eram estudantes, dois estavam sem respostas e três foram gerados em duplicidade pelo sistema. Restando, portanto 224 questionários que foram analisados para compor os resultados finais apresentados ao longo deste capítulo.

\section{1 Perfil do entrevistado}

Os dados que se referem ao perfil do público entrevistado estão apresentados abaixo nas TAB. 6 a 9. As principais características da população amostral são as seguintes:

- Compreendem a faixa etária entre 18 e 60 anos, sendo que a maioria está na faixa de 21 a 30 anos (TAB. 6);

- A média entre os sexos feminino e masculino está bem distribuída, sendo $48,66 \%$ feminino e $50 \%$ masculino (TAB. 6 );

- Maioria de solteiros, com 66,96\% (TAB. 7);

- $68,3 \%$ são estudantes de graduação, 30,82\% estudantes de pósgraduação (TAB. 8);

- 34,38\% cursam Ciências Sociais e Aplicadas, seguido pelas Ciências Humanas com 16,52\% e Ciências da Saúde com 13,39\% (TAB. 8);

- A distribuição entre o tipo de universidade também aparece bem equacionada, sendo $48,21 \%$ da rede particular e $51,79 \%$ da rede pública (TAB. 9); e

- A população, em sua maioria estuda na capital do estado de São Paulo (63,39\%) e na região metropolitana (18,75\%) (TAB. 9). 
TABELA 6 - Estudantes que responderam à pesquisa, de acordo com faixa etária e sexo

\section{SEXO}

\begin{tabular}{lccccc}
\hline FAIXA ETÁRIA & FEMININO & MASCULINO & NÃO INFORMOU & TOTAL GERAL & $\%$ \\
\hline $18-20$ anos & 15 & 18 & 0 & 33 & $14,73 \%$ \\
$21-25$ anos & 45 & 27 & 2 & 74 & $33,04 \%$ \\
$26-30$ anos & 22 & 23 & 1 & 46 & $20,54 \%$ \\
$31-35$ anos & 14 & 16 & 0 & 30 & $13,39 \%$ \\
$36-40$ anos & 5 & 3 & 0 & 8 & $3,57 \%$ \\
$41-45$ anos & 5 & 12 & 0 & 17 & $7,59 \%$ \\
$46-50$ anos & 2 & 8 & 0 & 10 & $4,46 \%$ \\
$51-55$ anos & 0 & 2 & 0 & 2 & $0,89 \%$ \\
$56-60$ anos & 0 & 3 & 0 & 3 & $1,34 \%$ \\
Não respondeu & 1 & 0 & 0 & 1 & $0,45 \%$ \\
\cline { 1 - 4 } TOTAL GERA & 109 & 112 & 3 & 224 & \\
\cline { 1 - 4 }$\%$ & $48,66 \%$ & $50,00 \%$ & $1,34 \%$ &
\end{tabular}

TABELA 7 - Estudantes que responderam à pesquisa, de acordo com estado civil

\begin{tabular}{lcc}
\hline ESTADO CIVIL & QUANTIDADE & $\%$ \\
\hline Solteiro & 150 & $66,96 \%$ \\
Casado & 1 & $0,45 \%$ \\
Casado com filhos & 40 & $17,86 \%$ \\
Casado sem filhos & 20 & $8,93 \%$ \\
Divorciado & 11 & $4,91 \%$ \\
Outros & 2 & $0,89 \%$ \\
\hline \multicolumn{1}{c}{ TOTAL } & 224 & \\
\hline
\end{tabular}

Para determinação das áreas do conhecimento foi utilizado Tabela de Áreas do Conhecimento disponibilizada pela Capes $^{3}$ (Coordenadoria de Aperfeiçoamento de Pessoal de Nível Superior).

\footnotetext{
${ }^{3}$ Disponível em: <http://www.capes.gov.br/avaliacao/tabela-de-areas-de-conhecimento>. Acesso em: 02 jun. 2010.
} 
TABELA 8 - Estudantes que responderam à pesquisa, de acordo com a escolaridade e área do conhecimento

\begin{tabular}{|c|c|c|c|c|c|c|c|c|}
\hline \multirow[b]{2}{*}{$\begin{array}{c}\text { ÁREAS DO } \\
\text { CONHECIMENTO }\end{array}$} & \multicolumn{6}{|c|}{ ESCOLARIDADE } & \multirow[b]{2}{*}{$\begin{array}{l}\text { TOTAL } \\
\text { GERAL }\end{array}$} & \multirow[b]{2}{*}{$\%$} \\
\hline & $\begin{array}{l}\text { GRADUA } \\
\text { ÇÃO }\end{array}$ & $\begin{array}{c}\text { PÓS- } \\
\text { GRADUAÇÃO }\end{array}$ & $\begin{array}{c}\text { MESTRA } \\
\text { DO }\end{array}$ & $\begin{array}{c}\text { DOUTORA } \\
\text { DO }\end{array}$ & $\begin{array}{c}\text { PÓS- } \\
\text { DOUTOR } \\
\text { ADO }\end{array}$ & $\begin{array}{c}\text { NÃO } \\
\text { RESPON } \\
\text { DEU }\end{array}$ & & \\
\hline Ciências Agrárias & 7 & 0 & 1 & 2 & 0 & 1 & 11 & $4,91 \%$ \\
\hline $\begin{array}{l}\text { Ciências } \\
\text { Biológicas }\end{array}$ & 2 & 0 & 3 & 5 & 0 & 0 & 10 & $4,46 \%$ \\
\hline $\begin{array}{l}\text { Ciências da } \\
\text { Saúde }\end{array}$ & 18 & 8 & 2 & 2 & 0 & 0 & 30 & $13,39 \%$ \\
\hline $\begin{array}{l}\text { Ciências Exatas e } \\
\text { da Terra }\end{array}$ & 20 & 1 & 3 & 3 & 0 & 1 & 28 & $12,50 \%$ \\
\hline $\begin{array}{l}\text { Ciências } \\
\text { Humanas }\end{array}$ & 30 & 3 & 3 & 1 & 0 & 0 & 37 & $16,52 \%$ \\
\hline $\begin{array}{l}\text { Ciências Sociais e } \\
\text { Aplicadas }\end{array}$ & 53 & 19 & 4 & 1 & 0 & 0 & 77 & $34,38 \%$ \\
\hline Engenharias & 13 & 0 & 0 & 3 & 0 & 0 & 16 & $7,14 \%$ \\
\hline $\begin{array}{l}\text { Linguística, Letras } \\
\text { e Artes }\end{array}$ & 9 & 1 & 1 & 0 & 0 & 0 & 11 & $4,91 \%$ \\
\hline Multidisciplinar & 1 & 0 & 0 & 1 & 0 & 0 & 2 & $0,89 \%$ \\
\hline Não respondeu & 0 & 0 & 1 & 0 & 1 & 0 & 2 & $0,89 \%$ \\
\hline TOTAL GERAL & 153 & 32 & 18 & 18 & 1 & 2 & 224 & \\
\hline$\%$ & $68,30 \%$ & $14,29 \%$ & $8,04 \%$ & $8,04 \%$ & $0,45 \%$ & $0,89 \%$ & & \\
\hline
\end{tabular}

TABELA 9 - Estudantes que responderam à pesquisa, de acordo com a Universidade e cidade em que estuda

UNIVERSIDADE

\begin{tabular}{lcccc}
\hline \multicolumn{1}{c}{ CIDADE } & PARTICULAR & PÚBLICA & TOTAL GERAL & $\%$ \\
\hline Capital & 60 & 82 & 142 & $63,39 \%$ \\
Metropolitana de SP & 39 & 3 & 42 & $18,75 \%$ \\
Outras cidades & 7 & 27 & 34 & $15,18 \%$ \\
Outros estados & 2 & 2 & 4 & $1,79 \%$ \\
EAD & 0 & 1 & 1 & $0,45 \%$ \\
Não respondeu & 0 & 1 & 1 & $0,45 \%$ \\
\cline { 1 - 4 }$\quad$ TOTAL GERAL & 108 & 116 & 224 & \\
\cline { 1 - 3 }$\%$ & $48,21 \%$ & $51,79 \%$ & \multicolumn{1}{c}{} \\
\cline { 1 - 3 }$\%$ & &
\end{tabular}

\section{2 Imagens}

Após a apresentação da imagem, foi solicitado que o entrevistado nomeasse-a conforme sua lembrança e indicasse o sentimento despertado.

O questionário $n^{\circ} 117$ foi excluído desta avaliação, pois estava sem respostas, portanto restaram apenas 223 , que foram analisados.

Esta análise dos questionários foi realizada determinando-se identificadores tanto para a nomeação das imagens, como para os sentimentos descritos para cada figura. 
Para demonstração final, foram considerados os identificadores que tiveram frequência de aparecimento maior do que 1\%. Em alguns questionários ao invés de apresentar ou descrever os sentimentos, o entrevistado, apresentou explicações ou justificativas para as imagens.

Abaixo apresentamos as imagens utilizadas e os resultados dos identificadores que mais apareceram na avaliação, podendo estar associados com outros termos.

A primeira imagem apresentada fazia referência à devastação da Floresta Amazônica, apresentada na FIG. 4. As palavras que são relacionadas à nomeação e aos sentimentos despertados são apresentadas nas TAB. 10 e 11.

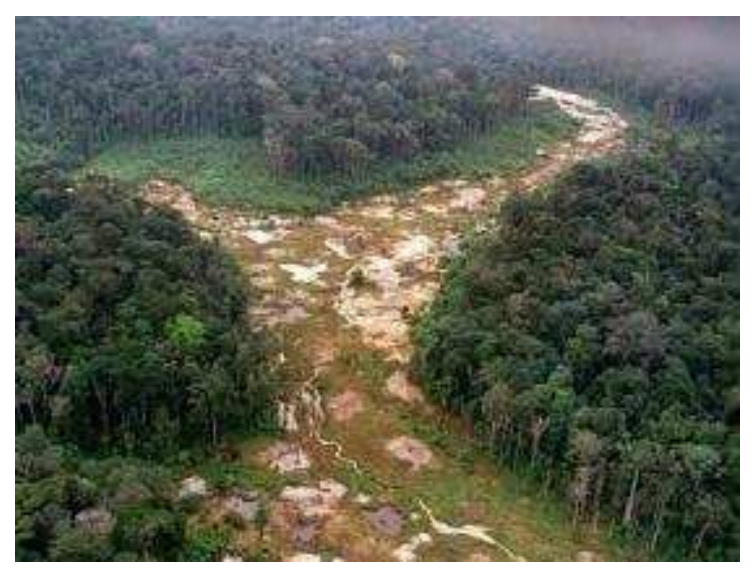

FIGURA 4 - Devastação da Floresta Amazônica ${ }^{4}$

TABELA 10 - Nomeação dada para a FIG. 4

\begin{tabular}{lcc}
\hline \multicolumn{3}{c}{ NOME } \\
\hline IDENTIFICADOR & FREQUÊNCIA & \% \\
\hline Desmatamento & 87 & $39,01 \%$ \\
Natureza & 28 & $12,56 \%$ \\
Rio & 15 & $6,73 \%$ \\
Amazônia & 12 & $5,38 \%$ \\
Estrada & 11 & $4,93 \%$ \\
Devastação & 10 & $4,48 \%$ \\
Destruição & 9 & $4,04 \%$ \\
Mata Atlântica & 4 & $1,79 \%$ \\
Degradação & 3 & $1,35 \%$ \\
\hline
\end{tabular}

\footnotetext{
${ }^{4}$ Disponível em:

<http://ultimosegundo.ig.com.br/brasil/2008/01/24/governo_discute_novas_medidas_de_combate_ ao_desmatamento_1163472.html>. Acesso em: 18 out. 2009.
} pela FIG 4

\begin{tabular}{lcr}
\multicolumn{3}{c}{ SENTIMENTO } \\
\hline IDENTIFICADOR & FREQUÊNCIA & \multicolumn{1}{c}{$\%$} \\
\hline Tristeza & 54 & $24,22 \%$ \\
Explicação & 25 & $11,21 \%$ \\
Indignação & 14 & $6,28 \%$ \\
Revolta & 14 & $6,28 \%$ \\
Impotência & 12 & $5,38 \%$ \\
Saudade & 9 & $4,04 \%$ \\
Angústia & 7 & $3,14 \%$ \\
Raiva & 7 & $3,14 \%$ \\
Medo & 6 & $2,69 \%$ \\
Preocupação & 6 & $2,69 \%$ \\
Solidão & 6 & $2,69 \%$ \\
Tranquilidade & 6 & $2,69 \%$ \\
Pena & 5 & $2,24 \%$ \\
\hline
\end{tabular}




\begin{tabular}{lcc}
\hline IDENTIFICADOR & FREQUÊNCIA & $\%$ \\
\hline Não respondeu & 5 & $2,24 \%$ \\
Dor & 4 & $1,79 \%$ \\
Nostalgia & 4 & $1,79 \%$ \\
Vazio & 4 & $1,79 \%$ \\
Desespero & 3 & $1,35 \%$ \\
Impunidade & 3 & $1,35 \%$ \\
\hline
\end{tabular}

A imagem foi reconhecida como desmatamento por $39,01 \%$ dos entrevistados e a Amazônia foi citada em 5,38\% das respostas (TAB. 10).

Esta figura foi ligada a sentimentos de tristeza, em $24,22 \%$ das respostas, e indignação e revolta em 12,56\% das entrevistas (TAB. 11).

Rio de Janeiro e Santa Catarina são termos que apareceram nas respostas de nomeação da imagem, pois os entrevistados recordaram de eventos recentes que ocorreram nestes Estados: alagamentos e deslizamentos devido às fortes chuvas. Isso demonstra o quanto a memória recente pode trazer à tona lembranças quando incitada com uma imagem que pode lembrar as cenas vistas.

A segunda imagem apresentada traz o acidente ocorrido em Chernobyl em 1986, como apresentado na FIG. 5. As palavras que são relacionadas à sua nomeação e aos sentimentos despertados estão apresentadas nas TAB. 12 e 13.

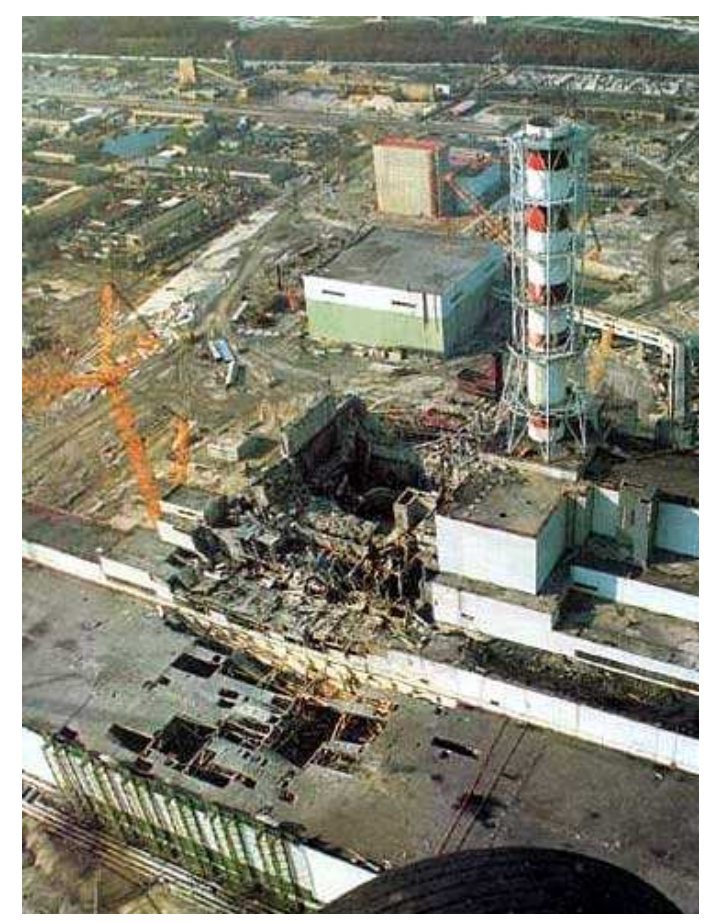

FIGURA 5 - Acidente em Chernobyl ${ }^{5}$

5 Disponível em: <http://www.grupoescolar.com/materia/acidentes_com_usinas_nucleares.html>. Acesso em: 18 out. 2009. 
TABELA 12 - Nomeação dada para a FIG. 5

\begin{tabular}{lcc}
\hline \multicolumn{3}{c}{ NOME } \\
\hline \multicolumn{1}{c}{ IDENTIFICADOR } & FREQUÊNCIA & $\%$ \\
\hline Destruição & 32 & $14,35 \%$ \\
Indústria & 28 & $12,56 \%$ \\
Abandono & 21 & $9,42 \%$ \\
Acidente & 11 & $4,93 \%$ \\
Chernobyl & 11 & $4,93 \%$ \\
Desastre & 11 & $4,93 \%$ \\
Explosão & 11 & $4,93 \%$ \\
Caos & 9 & $4,04 \%$ \\
Construção & 9 & $4,04 \%$ \\
Não respondeu & 9 & $4,04 \%$ \\
Desmoronamento & 5 & $2,24 \%$ \\
Desabamento & 4 & $1,79 \%$ \\
Poluição & 4 & $1,79 \%$ \\
Guerra & 3 & $1,35 \%$ \\
\hline
\end{tabular}

TABELA 13 - Sentimento despertado pela FIG. 5

\begin{tabular}{lcr}
\hline \multicolumn{3}{c}{ SENTIMENTO } \\
\hline \multicolumn{1}{c}{ IDENTIFICADOR } & FREQUÊNCIA & \multicolumn{1}{c}{$\%$} \\
\hline Explicação & 34 & $15,25 \%$ \\
Tristeza & 20 & $8,97 \%$ \\
Abandono & 16 & $7,17 \%$ \\
Medo & 11 & $4,93 \%$ \\
Não respondeu & 11 & $4,93 \%$ \\
Destruição & 8 & $3,59 \%$ \\
Preocupação & 7 & $3,14 \%$ \\
Descaso & 6 & $2,69 \%$ \\
Indiferença & 6 & $2,69 \%$ \\
Angústia & 5 & $2,24 \%$ \\
Vazio & 5 & $2,24 \%$ \\
Desespero & 4 & $1,79 \%$ \\
Impotência & 4 & $1,79 \%$ \\
Insegurança & 4 & $1,79 \%$ \\
Ruim & 4 & $1,79 \%$ \\
Confusão & 3 & $1,35 \%$ \\
Desânimo & 3 & $1,35 \%$ \\
Desgosto & 3 & $1,35 \%$ \\
Desolação & 3 & $1,35 \%$ \\
Desprezo & 3 & $1,35 \%$ \\
Estresse & 3 & $1,35 \%$ \\
Nenhum & 3 & $1,35 \%$ \\
Perda & 3 & $1,35 \%$ \\
Perigo & 3 & $1,35 \%$ \\
Revolta & 3 & $1,35 \%$ \\
\hline & &
\end{tabular}

O maior número de citações, 14,35\%, associou a imagem com destruição (representação do acidente), com a mesma freqüência, 4,93\%, Chernobyl foi associado com desastre e explosão (TAB. 12).

Os sentimentos de tristeza, abandono e medo aparecem com freqüência significativa, e estão ligados à nomeação, voltada a aspectos negativos (TAB. 13).

A terceira imagem apresentada faz referência a poluição na cidade de Cubatão em São Paulo, devida a industrialização acelerada na década de $80 \mathrm{e}$ está apresentada na FIG. 6. As palavras que são relacionadas à nomeação e aos sentimentos despertados estão apresentadas nas TAB. 14 e 15. 


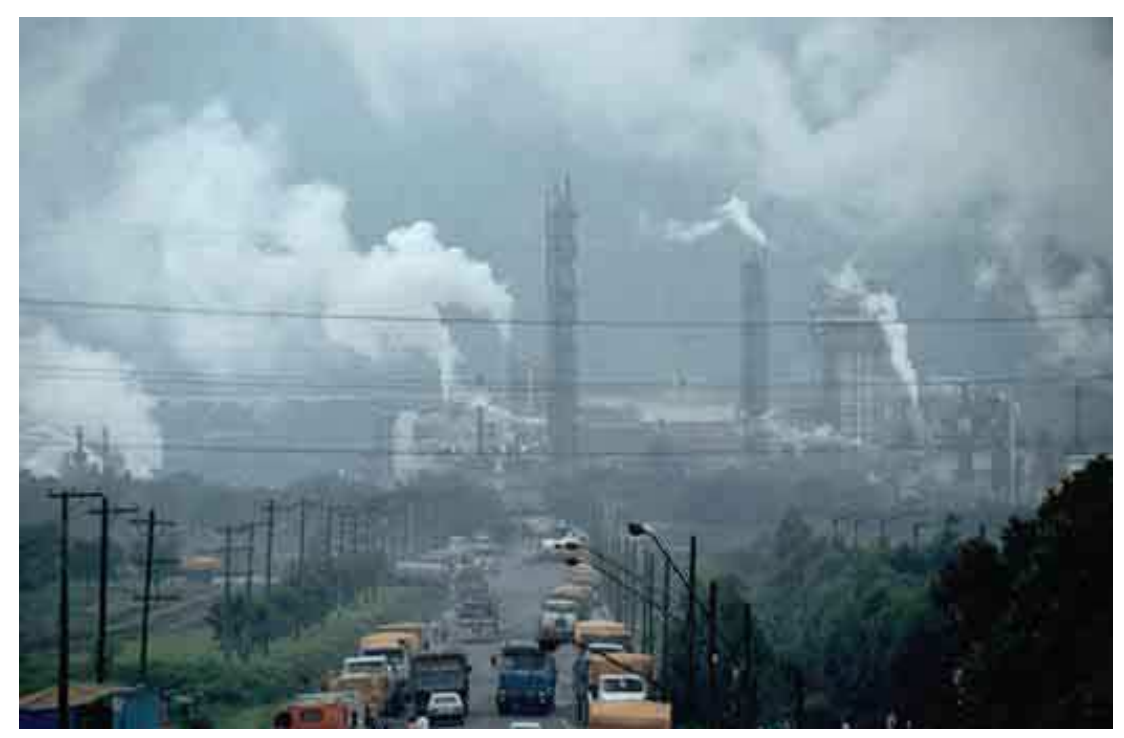

FIGURA 6 - Poluição em Cubatão ${ }^{6}$

TABELA 14 - Nomeação dada para a FIG. 6

\begin{tabular}{lcc}
\hline \multicolumn{3}{c}{ NOME } \\
\hline IDENTIFICADOR & FREQUÊNCIA & $\%$ \\
\hline Poluição & 118 & $52,91 \%$ \\
Cubatão & 17 & $7,62 \%$ \\
Indústria & 11 & $4,93 \%$ \\
Fumaça & 9 & $4,04 \%$ \\
Sufoco & 6 & $2,69 \%$ \\
Cidade & 5 & $2,24 \%$ \\
Cidade grande & 4 & $1,79 \%$ \\
Cinza & 3 & $1,35 \%$ \\
Morte & 3 & $1,35 \%$ \\
São Paulo & 3 & $1,35 \%$ \\
\hline
\end{tabular}

A maioria de $52,91 \%$ associou a imagem com poluição, ao passo que $7,62 \%$ indicaram a cidade de Cubatão em suas respostas, demonstrando o quanto a proximidade geográfica do fato permite que seja lembrado mais

facilmente. Além do que, a maioria da população considerada reside em São

\footnotetext{
${ }^{6}$ Disponível em: <http://mundogeografico.sites.uol.com.br/amb01.html>. Acesso em: 18 out. 2009.
}

\begin{tabular}{|c|c|c|}
\hline \multicolumn{3}{|c|}{ SENTIMENTO } \\
\hline IDENTIFICADOR & FREQUÊNCIA & $\%$ \\
\hline Sufoco & 39 & $17,49 \%$ \\
\hline Explicação & 39 & $17,49 \%$ \\
\hline Tristeza & 24 & $10,76 \%$ \\
\hline Nojo & 10 & $4,48 \%$ \\
\hline Angústia & 9 & $4,04 \%$ \\
\hline Medo & 8 & $3,59 \%$ \\
\hline Preocupação & 8 & $3,59 \%$ \\
\hline Revolta & 8 & $3,59 \%$ \\
\hline Raiva & 7 & $3,14 \%$ \\
\hline Desespero & 6 & $2,69 \%$ \\
\hline Descaso & 5 & $2,24 \%$ \\
\hline Impotência & 5 & $2,24 \%$ \\
\hline Indignação & 5 & $2,24 \%$ \\
\hline Aflição & 4 & $1,79 \%$ \\
\hline Adoecimento & 3 & $1,35 \%$ \\
\hline Cansaço & 3 & $1,35 \%$ \\
\hline Desânimo & 3 & $1,35 \%$ \\
\hline Desrespeito & 3 & $1,35 \%$ \\
\hline Nostalgia & 3 & $1,35 \%$ \\
\hline Não respondeu & 3 & $1,35 \%$ \\
\hline
\end{tabular}

TABELA 15 - Sentimento despertado pela FIG. 6 
Paulo, e deve, portanto, ter acesso à Cubatão, visto que está no caminho dos muitos paulistanos que se dirigem ao litoral do Estado (TAB. 14).

Os sentimentos de sufoco $(17,49 \%)$ e tristeza $(10,76 \%)$ aparecem com alta frequência, lembrando que o identificador sufoco, está relacionado a imagem nebulosa e de muita fumaça apresentada. O sentimento de sufoco pode ser entendido com a sensação de não mais suportar permanecer em um lugar assim, o que denota o limite aceitável da população estudada com o excesso de poluição (TAB. 15).

A quarta imagem se refere ao acidente ocorrido com o petroleiro Exxon Valdez em 1989 no litoral do Alasca e está representada na FIG. 7. As palavras que são relacionadas à nomeação e aos sentimentos despertados estão apresentadas nas TAB. 16 e 17.

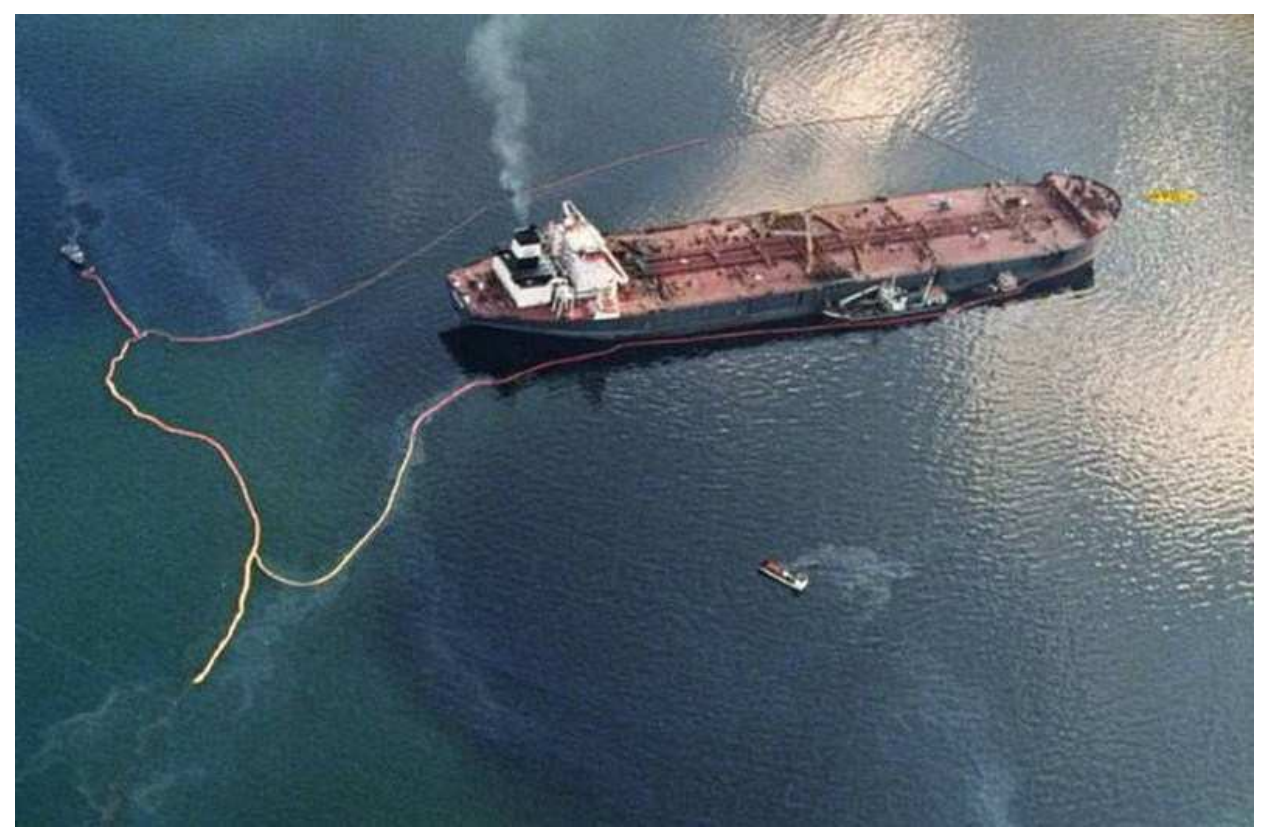

FIGURA 7 - Acidente com o Exxon Valdez ${ }^{7}$

TABELA 16 - Nomeação dada para a FIG. 7

\begin{tabular}{lcc}
\hline \multicolumn{3}{c}{ NOME } \\
\hline IDENTIFICADOR & FREQUÊNCIA & $\%$ \\
\hline Vazamento & 43 & $19,28 \%$ \\
Poluição & 22 & $9,87 \%$ \\
Oceano/Mar & 16 & $7,17 \%$ \\
Mancha de óleo & 11 & $4,93 \%$ \\
Não respondeu & 9 & $4,04 \%$ \\
Navio & 8 & $3,59 \%$
\end{tabular}

TABELA 17 - Sentimento despertado pela FIG. 7

\begin{tabular}{lcr}
\hline \multicolumn{3}{c}{ SENTIMENTO } \\
\hline IDENTIFICADOR & FREQUÊNCIA & $\%$ \\
\hline Explicação & 65 & $29,15 \%$ \\
Tristeza & 18 & $8,07 \%$ \\
Raiva & 16 & $7,17 \%$ \\
Indignação & 11 & $4,93 \%$ \\
Revolta & 11 & $4,93 \%$ \\
Não respondeu & 9 & $4,04 \%$
\end{tabular}

\footnotetext{
${ }^{7}$ Disponível em: <http://www.solcomhouse.com/valdez.htm>. Acesso em: 18 out. 2009.
} 


\begin{tabular}{lcc}
\hline IDENTIFICADOR & FREQUÊNCIA & $\%$ \\
\hline Petróleo & 7 & $3,14 \%$ \\
Cargueiro & 6 & $2,69 \%$ \\
Petroleiro & 6 & $2,69 \%$ \\
Desastre & 5 & $2,24 \%$ \\
Óleo & 5 & $2,24 \%$ \\
Pesca & 5 & $2,24 \%$ \\
Acidente & 4 & $1,79 \%$ \\
Crime & 4 & $1,79 \%$ \\
Destruição & 3 & $1,35 \%$ \\
\hline
\end{tabular}

\begin{tabular}{lcc}
\hline IDENTIFICADOR & FREQUÊNCIA & $\%$ \\
\hline Impotência & 8 & $3,59 \%$ \\
Angústia & 6 & $2,69 \%$ \\
Descaso & 6 & $2,69 \%$ \\
Dó & 6 & $2,69 \%$ \\
Tranquilidade & 6 & $2,69 \%$ \\
Pena & 5 & $2,24 \%$ \\
Medo & 4 & $1,79 \%$ \\
Descuido & 3 & $1,35 \%$ \\
Indiferença & 3 & $1,35 \%$ \\
Perda & 3 & $1,35 \%$ \\
Preocupação & 3 & $1,35 \%$ \\
\hline
\end{tabular}

Nenhuma resposta identificou diretamente a imagem com o acidente ocorrido com o Exxon Valdez, 19,28\%. A imagem foi associada com vazamento e 9,87\% com poluição (TAB. 16).

Os sentimentos de tristeza, raiva, indignação e revolta aparecem com maior frequência; muitos vazamentos em águas oceânicas acontecem e estão sempre sendo noticiados na imprensa (TAB. 17).

A quinta imagem apresentada faz referência ao acidente ocorrido na plataforma petrolífera Piper Alpha demonstrada na FIG. 8. As palavras que são relacionadas à nomeação e aos sentimentos despertados estão apresentadas nas TAB. 18 e 19.

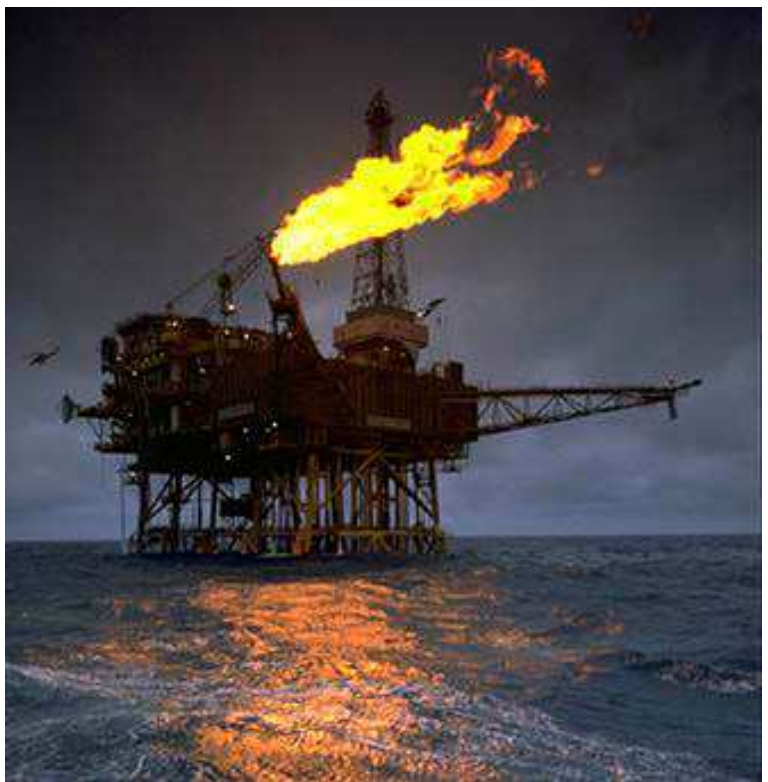

FIGURA 8 - Acidente em Piper Alpha ${ }^{8}$

\footnotetext{
${ }^{8}$ Disponível em: <http://www.10puntos.com/accidentes-mas-caros-de-la-historia/>. Acesso em: 18
} out. 2009. 
TABELA 18 - Nomeação dada para a FIG. 8

\begin{tabular}{lcc}
\hline \multicolumn{3}{c}{ NOME } \\
\hline \multicolumn{1}{c}{ IDENTIFICADOR } & FREQUÊNCIA & $\%$ \\
\hline Plataforma petrolífera & 55 & $24,66 \%$ \\
Fogo & 26 & $11,66 \%$ \\
Petróleo & 17 & $7,62 \%$ \\
Exploração & 9 & $4,04 \%$ \\
Extração & 6 & $2,69 \%$ \\
Petrobrás & 6 & $2,69 \%$ \\
Acidente & 5 & $2,24 \%$ \\
Progresso & 5 & $2,24 \%$ \\
Energia & 4 & $1,79 \%$ \\
Não respondeu & 4 & $1,79 \%$ \\
Tecnologia & 4 & $1,79 \%$ \\
Desperdício & 3 & $1,35 \%$ \\
Ganância & 3 & $1,35 \%$ \\
Petrolífero & 3 & $1,35 \%$ \\
Riquezas & 3 & $1,35 \%$ \\
\hline
\end{tabular}

TABELA 19 - Sentimento despertado pela FIG. 8

\begin{tabular}{lcr}
\hline \multicolumn{3}{c}{ SENTIMENTO } \\
\hline IDENTIFICADOR & FREQUÊNCIA & \multicolumn{1}{c}{$\%$} \\
\hline Explicação & 87 & $39,01 \%$ \\
Medo & 11 & $4,93 \%$ \\
Preocupação & 10 & $4,48 \%$ \\
Nenhum & 7 & $3,14 \%$ \\
Tristeza & 7 & $3,14 \%$ \\
Não respondeu & 6 & $2,69 \%$ \\
Ambição & 5 & $2,24 \%$ \\
Impotência & 5 & $2,24 \%$ \\
Orgulho & 5 & $2,24 \%$ \\
Indiferença & 4 & $1,79 \%$ \\
Perigo & 4 & $1,79 \%$ \\
Raiva & 4 & $1,79 \%$ \\
Curiosidade & 3 & $1,35 \%$ \\
Normal & 3 & $1,35 \%$ \\
Ódio & 3 & $1,35 \%$ \\
Solidão & 3 & $1,35 \%$ \\
\hline
\end{tabular}

A imagem não foi associada diretamente ao acidente na Piper Alpha, ou algum outro evento passado; $24,66 \%$ nomearam como plataforma petrolífera e $11,66 \%$ associaram com fogo. Associações com progresso, energia e tecnologia também foram feitas com frequência aproximada de $2 \%$ (TAB. 18).

Os sentimentos que mais apareceram apontam para medo $(4,93 \%)$ e preocupação $(4,48 \%)$ (TAB. 19).

A sexta imagem faz referência ao acidente ocorrido na usina nuclear de Three Mile Island em 1979, como apresentado na FIG. 9. As palavras que são relacionadas à nomeação e aos sentimentos despertados estão apresentadas nas TAB. 20 e 21. 


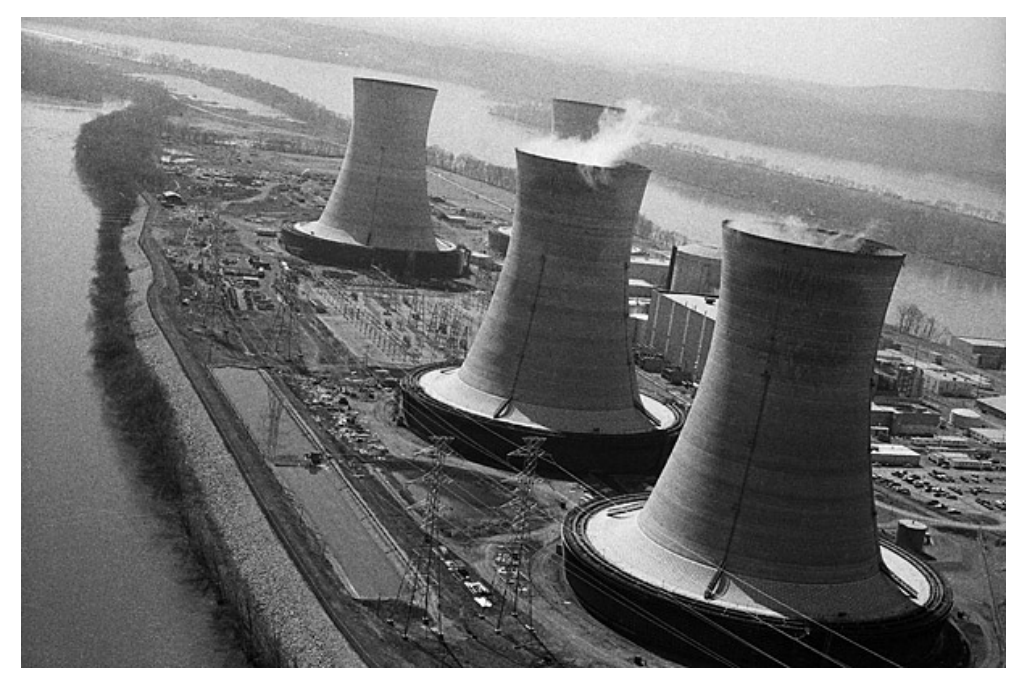

FIGURA 9 - Acidente em Three Mile Island ${ }^{9}$

TABELA 20 - Nomeação dada para a FIG. 9

\begin{tabular}{lcc}
\hline \multicolumn{3}{c}{ NOME } \\
\hline IDENTIFICADOR & FREQUÊNCIA & $\%$ \\
\hline Usina nuclear & 44 & $19,73 \%$ \\
Usina & 24 & $10,76 \%$ \\
Indústria & 19 & $8,52 \%$ \\
Nuclear & 14 & $6,28 \%$ \\
Energia & 13 & $5,83 \%$ \\
Poluição & 13 & $5,83 \%$ \\
Tecnologia & 7 & $3,14 \%$ \\
Não respondeu & 5 & $2,24 \%$ \\
Grandeza & 4 & $1,79 \%$ \\
Futuro & 3 & $1,35 \%$ \\
Reatores & 3 & $1,35 \%$ \\
Termoelétrica & 3 & $1,35 \%$ \\
Three Mile Island & 3 & $1,35 \%$ \\
\hline
\end{tabular}

TABELA 21 - Sentimento despertado pela FIG. 9

\begin{tabular}{lcc}
\multicolumn{3}{c}{ SENTIMENTO } \\
\hline IDENTIFICADOR & FREQUÊNCIA & $\%$ \\
\hline Explicação & 72 & $32,29 \%$ \\
Medo & 31 & $13,90 \%$ \\
Preocupação & 15 & $6,73 \%$ \\
Indiferença & 7 & $3,14 \%$ \\
Tristeza & 7 & $3,14 \%$ \\
Não respondeu & 7 & $3,14 \%$ \\
Impotência & 4 & $1,79 \%$ \\
Incerteza & 4 & $1,79 \%$ \\
Nojo & 4 & $1,79 \%$ \\
Perigo & 4 & $1,79 \%$ \\
Angústia & 3 & $1,35 \%$ \\
Insegurança & 3 & $1,35 \%$ \\
Poder & 3 & $1,35 \%$ \\
Risco & 3 & $1,35 \%$ \\
Sufoco & 3 & $1,35 \%$ \\
\hline
\end{tabular}

A imagem foi associada ao termo nuclear por $27,36 \%$ dos entrevistados, mas apenas 1,35\% identificaram como Three Mile Island (TAB. 20). Os sentimentos de medo, com $13,9 \%$ e preocupação, com $6,73 \%$ apareceram em primeiro lugar, seguidos por indiferença com 3,14\%. Outro apontamento interessante foi o termo poder com 1,35\% (TAB. 21).

A sétima imagem apresentada se refere ao abalo sísmico ocorrido no Oceano Índico em 2004, que teve como consequência o tsunami em Sumatra, na

\footnotetext{
${ }^{9}$ Disponível em: <http://journaluga.ru/archives/48-Atomnye_katastrofy..html>. Acesso em: 18 out. 2009.
} 
África, mostrado na FIG. 10. As palavras que são relacionadas à nomeação e aos sentimentos despertados estão apresentadas nas TAB. 22 e 23.

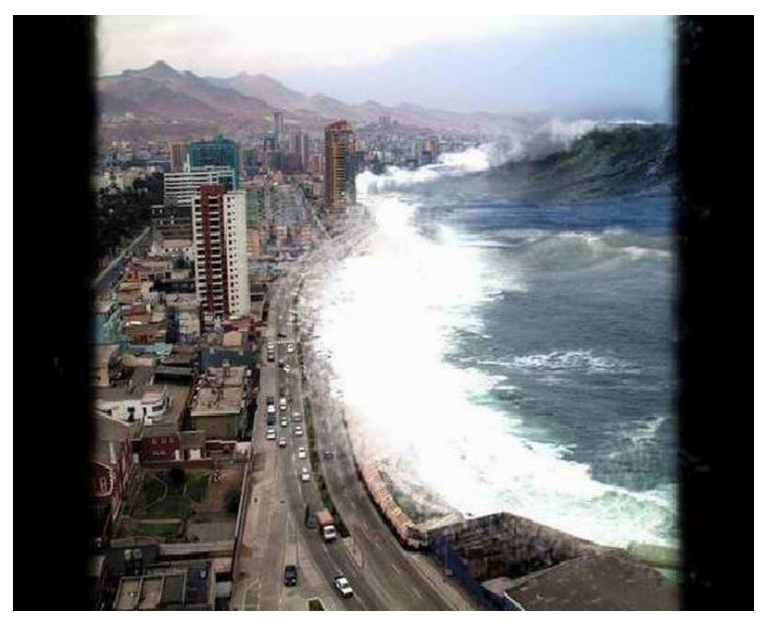

FIGURA 10 - Tsunami $^{10}$

TABELA 22 - Nomeação dada para a FIG. 10

\begin{tabular}{lcc}
\hline \multicolumn{3}{c}{ NOME } \\
\hline \multicolumn{1}{c}{ IDENTIFICADOR } & FREQUÊNCIA & $\%$ \\
\hline Tsunami & 89 & $39,91 \%$ \\
Ressaca & 11 & $4,93 \%$ \\
Maremoto & 9 & $4,04 \%$ \\
Vingança & 8 & $3,59 \%$ \\
Natureza & 6 & $2,69 \%$ \\
Catástrofe & 5 & $2,24 \%$ \\
Desastre & 5 & $2,24 \%$ \\
Montagem & 5 & $2,24 \%$ \\
Fúria da natureza & 5 & $2,24 \%$ \\
Resposta da natureza & 5 & $2,24 \%$ \\
Onda & 5 & $2,24 \%$ \\
Futuro & 4 & $1,79 \%$ \\
Revolta & 4 & $1,79 \%$ \\
Aquecimento global & 3 & $1,35 \%$ \\
Filme & 3 & $1,35 \%$ \\
Oceano/Mar & 3 & $1,35 \%$ \\
Mar enfurecido & 3 & $1,35 \%$ \\
Não respondeu & 3 & $1,35 \%$ \\
\hline
\end{tabular}

TABELA 23 - Sentimento despertado pela FIG. 10

\begin{tabular}{lcr}
\hline \multicolumn{3}{c}{ SENTIMENTO } \\
\hline IDENTIFICADOR & FREQUÊNCIA & \multicolumn{1}{c}{$\%$} \\
\hline Explicação & 66 & $29,60 \%$ \\
Medo & 47 & $21,08 \%$ \\
Tristeza & 12 & $5,38 \%$ \\
Impotência & 9 & $4,04 \%$ \\
Desespero & 8 & $3,59 \%$ \\
Angústia & 6 & $2,69 \%$ \\
Pavor & 6 & $2,69 \%$ \\
Preocupação & 6 & $2,69 \%$ \\
Insegurança & 5 & $2,24 \%$ \\
Fúria & 4 & $1,79 \%$ \\
Pena & 4 & $1,79 \%$ \\
Revolta & 4 & $1,79 \%$ \\
Dó & 3 & $1,35 \%$ \\
Espanto & 3 & $1,35 \%$ \\
Nenhum & 3 & $1,35 \%$ \\
Pânico & 3 & $1,35 \%$ \\
Não respondeu & 2 & $0,90 \%$ \\
\hline
\end{tabular}

A maioria, de $48,88 \%$, dos entrevistados associou a figura apresentada com tsunami, ressaca e maremoto, trazendo à tona os eventos sobre o tema (TAB. 22).

\footnotetext{
${ }^{10}$ Disponível em: <http://detrolhaaengenheiro.wordpress.com/2007/09/27/cientistas-receiam-novotsunami-catastrofico-em-sumatra/>. Acesso em: 18 out. 2009.
} 
O sentimento de medo aparece em primeiro lugar, com 21,08\%, seguido por tristeza com $5,38 \%$, o que demonstra que o medo impera nesta questão (TAB. 23).

A oitava imagem faz referência ao World Trade Center em Nova lorque em 2001, demonstrado na FIG. 11. As palavras que são relacionadas à nomeação e aos sentimentos despertados estão apresentadas nas TAB. 24 e 25.

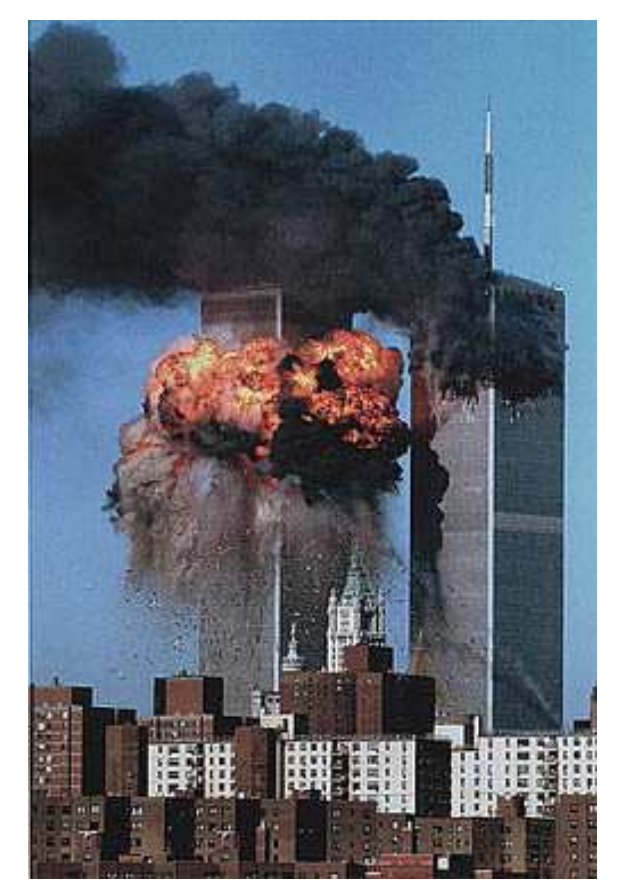

FIGURA 11 - Atentado Terrorista ${ }^{11}$

TABELA 24 - Nomeação dada para a FIG. 11

\begin{tabular}{lcc}
\hline \multicolumn{3}{c}{ NOME } \\
\hline \multicolumn{1}{c}{ IDENTIFICADOR } & FREQUÊNCIA & $\%$ \\
\hline 11 de setembro & 36 & $16,14 \%$ \\
Terrorismo & 31 & $13,90 \%$ \\
Torres gêmeas & 24 & $10,76 \%$ \\
World Trade Center & 17 & $7,62 \%$ \\
Atentado & 9 & $4,04 \%$ \\
Intolerância & 5 & $2,24 \%$ \\
Tragédia & 5 & $2,24 \%$ \\
Destruição & 4 & $1,79 \%$ \\
Estados Unidos & 4 & $1,79 \%$ \\
Guerra & 4 & $1,79 \%$ \\
Desastre & 3 & $1,35 \%$ \\
Morte & 3 & $1,35 \%$ \\
\hline
\end{tabular}

TABELA 25 - Sentimento despertado pela FIG. 11

\begin{tabular}{lcc}
\hline \multicolumn{3}{c}{ SENTIMENTO } \\
\hline IDENTIFICADOR & FREQUÊNCIA & $\%$ \\
\hline Explicação & 47 & $21,08 \%$ \\
Tristeza & 32 & $14,35 \%$ \\
Revolta & 19 & $8,52 \%$ \\
Medo & 16 & $7,17 \%$ \\
Indignação & 8 & $3,59 \%$ \\
Desespero & 7 & $3,14 \%$ \\
Vingança & 7 & $3,14 \%$ \\
Impotência & 6 & $2,69 \%$ \\
Pena & 6 & $2,69 \%$ \\
Espanto & 5 & $2,24 \%$ \\
Raiva & 5 & $2,24 \%$ \\
Dor & 4 & $1,79 \%$ \\
Perplexidade & 4 & $1,79 \%$ \\
Surpresa & 4 & $1,79 \%$ \\
\hline
\end{tabular}

${ }^{11}$ Disponível em: <http://www.effguide.com/2009/09/what-happened-on-september-11-2001-911/>. Acesso em: 18 out. 2009. 


\begin{tabular}{lcc}
\hline IDENTIFICADOR & FREQUÊNCIA & $\%$ \\
\hline Angústia & 3 & $1,35 \%$ \\
Desamor & 3 & $1,35 \%$ \\
Ignorância & 3 & $1,35 \%$ \\
Insegurança & 3 & $1,35 \%$ \\
Intolerância & 3 & $1,35 \%$ \\
Não respondeu & 3 & $1,35 \%$ \\
\hline
\end{tabular}

Esta imagem foi utilizada como fuga ao tema central da pesquisa, para evitar o vício nas respostas dos entrevistados, pois não se refere a um evento nuclear e nem a um evento ambiental.

Pode ser considerado que a quase totalidade dos respondentes identificou a figura apresentada com o evento ocorrido em Nova lorque/EUA (TAB. 24).

E os sentimentos que prevaleceram foram o de tristeza $(14,35 \%)$, de revolta $(8,52 \%)$, de medo $(7,17 \%)$ e de indignação $(3,59 \%)$ (TAB. 25$)$.

A nona imagem apresentada se refere ao evento brasileiro ocorrido em 1987, na cidade de Goiânia e está demonstrado na FIG. 12. As palavras que são relacionadas à nomeação e aos sentimentos despertados estão apresentadas nas TAB. 26 e 27.

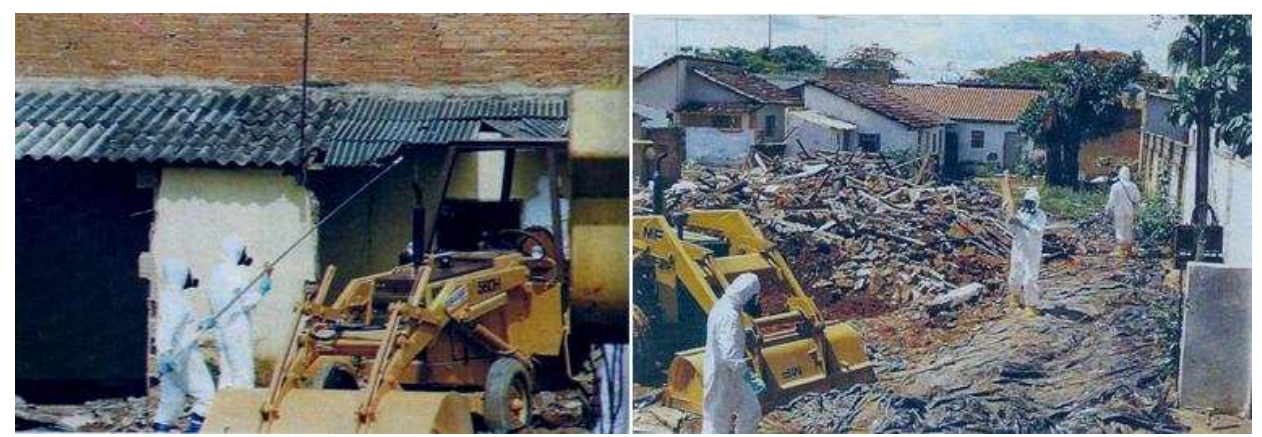

FIGURA 12 - Acidente radiológico de Goiânia ${ }^{12}$

TABELA 26 - Nomeação dada para a TABELA 27 - Sentimento despertado FIG. 12

\begin{tabular}{|c|c|c|c|c|c|}
\hline \multicolumn{3}{|c|}{ NOME } & \multicolumn{3}{|c|}{ SENTIMENTO } \\
\hline IDENTIFICADOR & FREQUÊNCIA & $\%$ & IDENTIFICADOR & FREQUÊNCIA & $\%$ \\
\hline Contaminação & 13 & $5,83 \%$ & Explicação & 54 & $24,22 \%$ \\
\hline Demolição & 13 & $5,83 \%$ & Tristeza & 33 & $14,80 \%$ \\
\hline Destruição & 12 & $5,38 \%$ & Medo & 17 & $7,62 \%$ \\
\hline Goiânia & 12 & $5,38 \%$ & Não respondeu & 16 & $7,17 \%$ \\
\hline
\end{tabular}

12 Disponível em: INTERNATIONAL ATOMIC ENERGY AGENCY. The radiological accident in Goiânia. Vienna, 1988. Photographs 4, sec. 4.1, p. [93]. 


\begin{tabular}{|c|c|c|c|c|c|}
\hline IDENTIFICADOR & FREQUÊNCIA & $\%$ & IDENTIFICADOR & FREQUÊNCIA & $\%$ \\
\hline Não respondeu & 12 & $5,38 \%$ & Revolta & 14 & $6,28 \%$ \\
\hline Desastre & 9 & $4,04 \%$ & Pena & 11 & $4,93 \%$ \\
\hline Desapropriação & 7 & $3,14 \%$ & Preocupação & 9 & $4,04 \%$ \\
\hline Terremoto & 7 & $3,14 \%$ & Descaso & 6 & $2,69 \%$ \\
\hline Risco & 6 & $2,69 \%$ & Não sei & 5 & $2,24 \%$ \\
\hline Desabamento & 5 & $2,24 \%$ & Raiva & 5 & $2,24 \%$ \\
\hline Desmoronamento & 5 & $2,24 \%$ & Impotência & 4 & $1,79 \%$ \\
\hline Acidente nuclear & 4 & $1,79 \%$ & Indignação & 4 & $1,79 \%$ \\
\hline Casas & 4 & $1,79 \%$ & Insegurança & 4 & $1,79 \%$ \\
\hline Pobreza & 4 & $1,79 \%$ & Angústia & 3 & $1,35 \%$ \\
\hline Radioatividade & 4 & $1,79 \%$ & Dó & 3 & $1,35 \%$ \\
\hline Césio 137 & 3 & $1,35 \%$ & Irresponsabilidade & 3 & $1,35 \%$ \\
\hline Descaso & 3 & $1,35 \%$ & Nenhum & 3 & $1,35 \%$ \\
\hline Epidemia & 3 & $1,35 \%$ & Perda & 3 & $1,35 \%$ \\
\hline Explosão & 3 & $1,35 \%$ & Solidariedade & 3 & $1,35 \%$ \\
\hline Não sei & 3 & $1,35 \%$ & & & \\
\hline Radiação & 3 & $1,35 \%$ & & & \\
\hline
\end{tabular}

Nesta figura 5,38\% identificaram como Goiânia, e 1,35\% como Césio 137, a ocorrência do acidente em solo brasileiro contribuiu para trazer o fato mais facilmente à memória (TAB. 26).

Os sentimentos de tristeza $(14,80 \%)$ e medo $(7,62 \%)$ foram despertados na maioria dos entrevistados (TAB. 27).

O público estudado é jovem, com mais de $68 \%$ na faixa etária de 18 a 30 anos (TAB. 6), e que portanto nasceram entre 1980 e 1992 (a amostragem é de 2010) ao passo que a maior parte dos acidentes mostrados ocorreu entre 1979 e 1989, somente dois ocorreram após o ano 2000, tsunami e o atentado ao World Trade Center. A data de ocorrência pouco influenciou na nomeação das imagens, os fatos recentes são recordados em suas lembranças, tanto quanto os fatos mais antigos.

Uma boa análise pode ser obtida dividindo as imagens em dois grupos, um grupo para as figuras que se relacionam à percepção ambiental e outro à percepção nuclear, o que possibilita uma melhor visualização e comparação dos sentimentos apontados.

Para demonstração final, foram considerados os dois identificadores que tiveram maior frequência de aparecimento (FIG. 13 e 14). 
GRUPO 1: PERCEPÇÃO AMBIENTAL

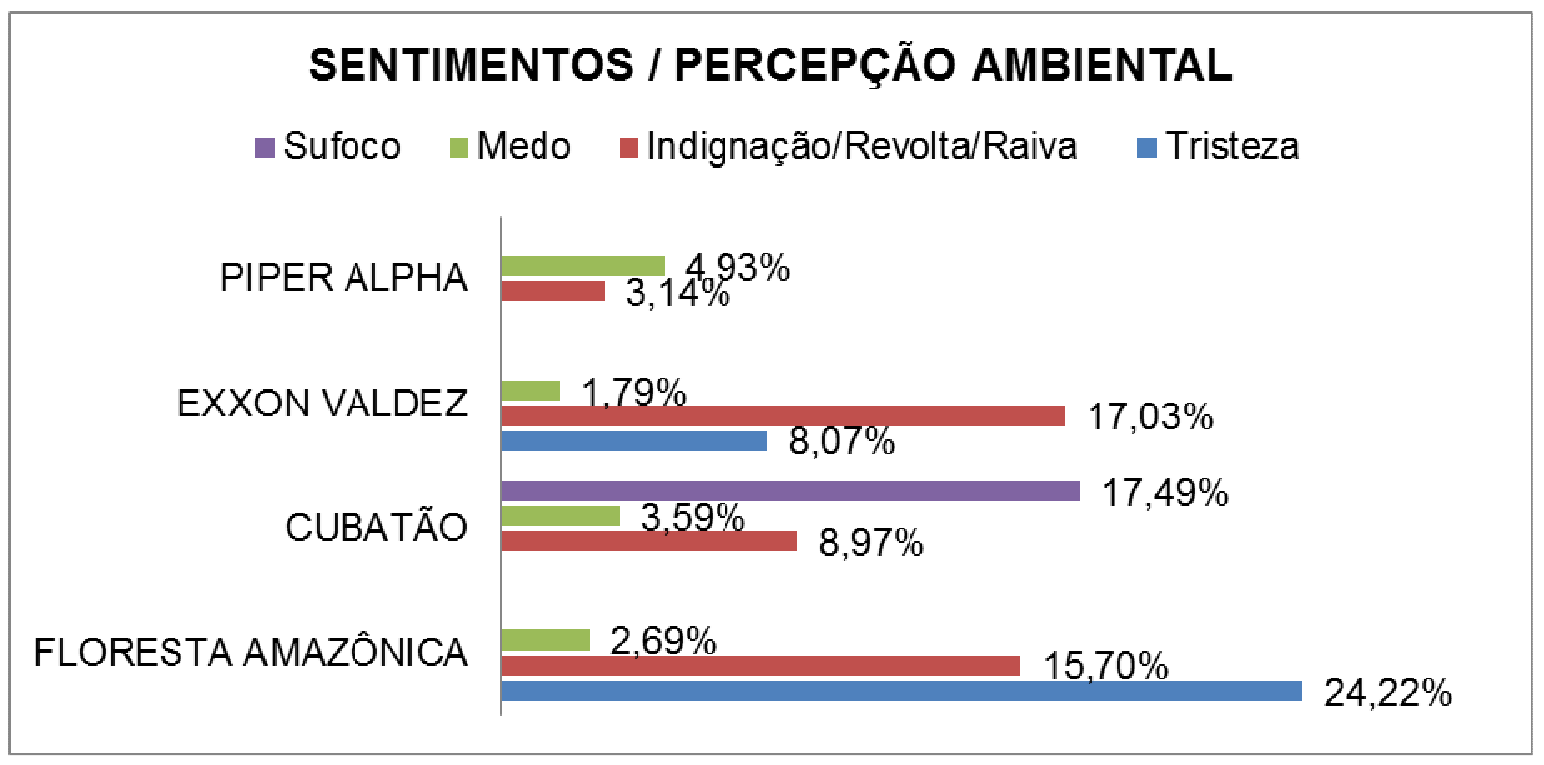

FIGURA 13 - Sentimentos sobre os eventos do grupo da percepção ambiental

\section{GRUPO 2: PERCEPÇÃO NUCLEAR}

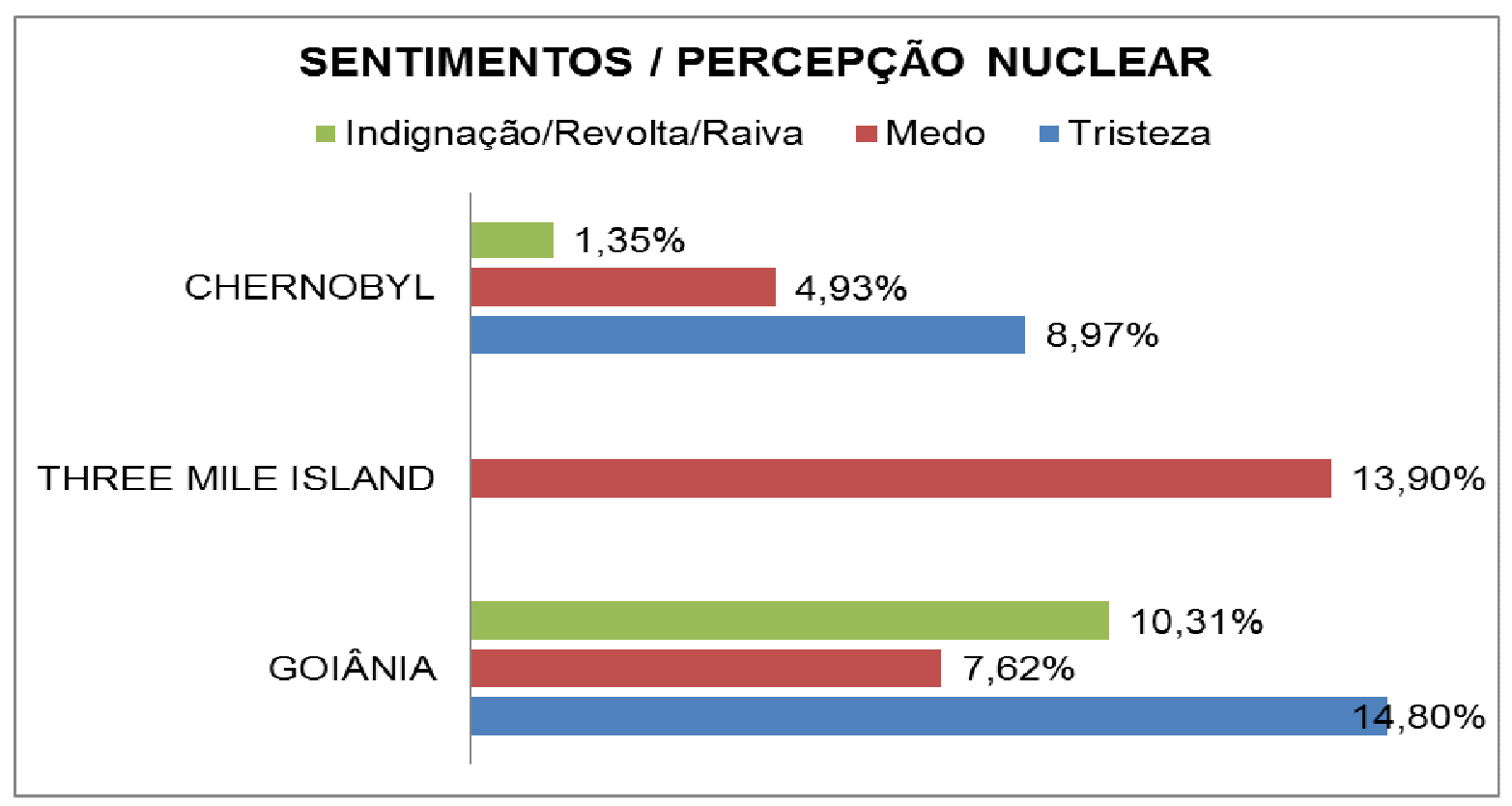

FIGURA 14 - Sentimentos sobre os eventos do grupo da percepção nuclear

Os sentimentos de raiva, revolta, ódio e indignação, foram somados, para cada figura. Estes foram considerados sentimentos negativos diante da possível aceitação, pois dificilmente serão substituídos por sentimentos positivos que possam auxiliar no convencimento de aceitação do público. Médias foram 
calculadas, portanto, para a presença destes sentimentos nas duas grandes áreas.

Nas imagens que representam a percepção ambiental (FIG. 13), a média destes sentimentos é de $11,21 \%$, ao passo que nas imagens que representam a percepção nuclear (FIG. 14) é de 3,88\%.

O sentimento de medo está diretamente associado às noções de perigo e risco (construídos histórica e socialmente), portanto é uma resposta socialmente regrada a situações percebidas como ameaçadoras (Rezende e Coelho, 2010).

A média do sentimento medo nas imagens que representam a percepção ambiental (FIG. 13) é de 3,25\%, ao passo que nas imagens que representa percepção nuclear (FIG. 14) é de 8,81\%.

Bernstein (1997, p. 70) aponta que "o medo do dano deveria ser proporcional, não apenas à gravidade do dano, mas também à probabilidade do evento", portanto, a tomada de decisão deve ser influenciada tanto pela gravidade como pela probabilidade.

Com relação à nomeação das imagens, verifica-se que estas, quando referentes a assuntos ocorridos no Brasil, foram associadas mais facilmente, assim como apontado por Slovic (2004) aspectos como familiaridade e potencial catastrófico estão ligados ao julgamento para a percepção de risco.

\section{3 Escala}

Solicitou-se ao entrevistado que ordenasse as atividades apresentadas, com quesitos de 1 a 10 (sem repetir as notas), sendo o 1 o menos perigoso e o 10 o mais perigoso.

Os questionários $\mathrm{n}^{\circ} 35$ e 126 foram excluídos desta avaliação, pois estavam sem respostas, e os questionários $\mathrm{n}^{\circ} 1,7,11,12,15,28,32,33,48,54$, $62,63,73,76,81,82,88,94,97,101,104,107,113,144,150,155,158,172$, 192, 194, 196, 199, 211, 215, 216 e 225, apresentaram repetição da nota para as atividades e também foram excluídos. Portanto restaram 186 questionários que foram avaliados de acordo com o que está apresentado a seguir (TAB. 28 e 29). 
TABELA 28 - Escala de risco para determinadas atividades (mais perigosas)

\begin{tabular}{lc}
\hline \multicolumn{1}{c}{ ATIVIDADE } & MAIS PERIGOSO (9-10) \\
\hline Destruição da camada de ozônio & $41,40 \%$ \\
Efeito estufa & $24,73 \%$ \\
Desmatamento & $24,73 \%$ \\
Reator nuclear & $23,12 \%$ \\
Poluição dos rios & $21,51 \%$ \\
Fumar & $20,97 \%$ \\
Colesterol & $11,83 \%$ \\
Emissão de fumaça & $10,75 \%$ \\
Viagem de avião & $9,68 \%$ \\
Hidroelétrica & $8,60 \%$ \\
\hline
\end{tabular}

1. Citações com número 9 e 10, representam mais perigo na atividade.

TABELA 29 - Escala de risco para determinadas atividades (menos perigosas)

\begin{tabular}{lc}
\hline \multicolumn{1}{c}{ ATIVIDADE } & MENOS PERIGOSO (1-2) \\
\hline Viagem de avião & $80,65 \%$ \\
Hidroelétrica & $43,55 \%$ \\
Colesterol & $27,96 \%$ \\
Fumar & $14,52 \%$ \\
Reator nuclear & $14,52 \%$ \\
Emissão de fumaça & $4,30 \%$ \\
Destruição da camada de ozônio & $4,30 \%$ \\
Efeito estufa & $3,76 \%$ \\
Poluição dos rios & $3,23 \%$ \\
Desmatamento & $2,69 \%$ \\
\hline
\end{tabular}

2. Citações com número 1 e 2, representam menos perigo na atividade.

$\mathrm{Na}$ TAB. 28 a escala apresentada demonstra que dentre as atividades apontadas, a considerada de maior risco foi a Destruição da Camada de Ozônio, com $41,40 \%$, seguida pelo Desmatamento e o Efeito Estufa, ambos com $24,73 \%$, o Reator Nuclear só aparece em quarto lugar com $23,12 \%$.

Considerando o extremo oposto, de menor risco, na TAB. 29, a atividade que aparece em primeiro lugar é Viagem de Avião, com 80,65\%, seguida pela Hidroelétrica, com 43,55\%. As últimas posições nesta escala ficam para as atividades ambientais, como Desmatamento, com 2,69\%, Poluição dos Rios, com 3,23\%, Efeito Estufa com 3,76\%, Emissão de fumaça e Destruição da Camada de Ozônio, ambas com 4,3\%, sendo que o Reator Nuclear aparece com $14,52 \%$, considerado, portanto menos perigoso, que as atividades relacionadas às questões ambientais.

Portanto, a aviação e a hidroelétrica em ambos os casos, foram consideradas as atividades menos perigosas. $O$ fato de estarem mais presentes 
no dia a dia da população e de serem mais conhecidas, pode ter influenciado nos resultados, pois os riscos mais conhecidos são os mais facilmente aceitáveis. Assim como destruição da camada de ozônio e o efeito estufa foram considerados de alta periculosidade, são perigos que são "invisíveis" aos olhos comuns e estão fora do alcance do homem, logo este não pode manipular para evitar o perigo ou minimizá-lo.

Assim como no estudo de Sjöberg e Drottz-Sjöberg (1994), os resultados demonstram que os riscos percebidos como menos perigosos estão relacionados aqueles que se pode ter controle sobre o risco, ou seja, aqueles em que acredita ser possível se proteger, como os riscos provenientes da destruição da camada de ozônio, do efeito estufa, do desmatamento, dos reatores nucleares, da poluição dos rios, não estão ao alcance do controle individual.

Em comparação com os estudos de Fischhoff et al (2004), os resultados aqui apresentados (TAB. 28 e 29), também apontam que a sociedade tolera uma série de atividades avaliadas pelos entrevistados como tendo pouco benefício e muito risco (por exemplo, o tabagismo e a emissão de fumaça).

\section{4 Questionário}

\subsubsection{Associação à energia nuclear}

Solicitou-se que o entrevistado escrevesse o que lhe vinha à mente quando ouvia o termo energia nuclear.

Os questionários $n^{\circ} 62,63,64,104,126,152$ e 156, foram excluídos desta avaliação, pois estavam sem respostas. Portanto restaram 217 questionários que foram avaliados de acordo com o que se segue.

Os questionários foram avaliados em duas etapas, primeiramente verificou-se se sua posição apresentava visão positiva, negativa, ambígua ou neutra (TAB. 30), em seguida, foram definidos identificadores e contados por quantidade de aparecimento (TAB. 31). 
TABELA 30 - Postura relacionada ao termo energia nuclear

\begin{tabular}{lcc}
\hline VISÃO & FREQUÊNCIA & $\%$ \\
\hline Negativa & 102 & $47,00 \%$ \\
Ambígua & 60 & $27,65 \%$ \\
Positiva & 36 & $16,59 \%$ \\
Neutra & 19 & $8,76 \%$ \\
\hline TOTAL & $\mathbf{2 1 7}$ & \\
\hline
\end{tabular}

TABELA 31 - Identificador associado ao termo energia nuclear

\begin{tabular}{lcc}
\hline IDENTIFICADOR & FREQUÊNCIA & $\%$ \\
\hline Energia & 89 & $41,01 \%$ \\
Perigo & 61 & $28,11 \%$ \\
Bombas & 29 & $13,36 \%$ \\
Desenvolvimento & 28 & $12,90 \%$ \\
Acidentes & 23 & $10,60 \%$ \\
Lixo e rejeitos & 23 & $10,60 \%$ \\
Guerra & 21 & $9,68 \%$ \\
Contaminação & 15 & $6,91 \%$ \\
Poluição & 10 & $4,61 \%$ \\
Tecnologia & 10 & $4,61 \%$ \\
Armas & 8 & $3,69 \%$ \\
Doenças & 7 & $3,23 \%$ \\
Alto investimento & 6 & $2,76 \%$ \\
Reatores e usinas & 6 & $2,76 \%$ \\
Desnecessária & 4 & $1,84 \%$ \\
\hline
\end{tabular}

$\mathrm{Na}$ análise das TAB. 30 e 31 , nota-se que apesar de $47 \%$ apresentarem uma visão negativa, $41,01 \%$ associaram a energia nuclear com a produção de energia elétrica, o desenvolvimento e a tecnologia, o que remete uma visão positiva, porém a questão aberta permitiu que o estudante apresentasse diversas opiniões, outros pontos negativos foram apontados no desenvolvimento da resposta, como bombas, guerras e acidentes, a argumentação volta-se para a questão da produção de energia que favorece o uso da tecnologia e o desenvolvimento do país mediante exposição a diversos riscos.

Nesta argumentação surgiram recordações dos acidentes ocorridos no passado e dos ataques nucleares, o que demonstra a forte influência dos fatos na tomada de posição da população estudada diante da tecnologia nuclear. 
Por outro lado, $16,59 \%$ apontam uma visão positiva, concordam com a existência do risco, mas julgam que o desenvolvimento da tecnologia pode trazer frutos benéficos para a população. Valorizando sempre a boa administração e lembrando a questão do gerenciamento dos rejeitos radioativos.

Ponce (2002, p. 31) salienta que a significação dada pelo sujeito está diretamente ligada à interpretação, que traz "à tona a história na qual está inserido bem como o seu conhecimento de mundo", portanto o sistema está em constante atividade e em relação com a exterioridade, produzindo ideologia e criando os atores sociais.

\subsubsection{Associação à degradação ambiental}

Solicitou-se que o entrevistado escrevesse o que lhe vinha à mente quando ouvia o termo degradação ambiental.

Os questionários $n^{0} 4,8,61,62,73,80,84,94,97,104,106,107,117$, 126, 128, 152, 178, 195, 196, 199 e 226, foram excluídos desta avaliação, pois estavam sem respostas. Portanto restaram 202 questionários que foram avaliados de acordo com o que se segue.

Os questionários foram avaliados em duas etapas, primeiramente verificou-se se sua posição apresentava visão positiva, negativa, ambígua ou neutra (TAB. 32), em seguida, foram definidos identificadores e contados por número de aparecimento (TAB. 33).

TABELA 32 - Postura relacionada ao termo degradação ambiental

\begin{tabular}{lcc}
\hline VISÃO & FREQUÉNCIA & $\%$ \\
\hline Negativa & 196 & $90,32 \%$ \\
Neutra & 5 & $2,30 \%$ \\
Positiva & 1 & $0,46 \%$ \\
Ambígua & 0 & $0,00 \%$ \\
\hline TOTAL & $\mathbf{2 0 2}$ & \\
\hline
\end{tabular}


TABELA 33 - Identificador associado ao termo degradação ambiental

\begin{tabular}{lcc}
\hline \multicolumn{1}{c}{ IDENTIFICADOR } & FREQUÊNCIA & $\%$ \\
\hline Poluição & 38 & $18,81 \%$ \\
Destruição & 28 & $13,86 \%$ \\
Desmatamento & 24 & $11,88 \%$ \\
Extinção & 23 & $11,39 \%$ \\
Mudanças climáticas & 14 & $6,93 \%$ \\
Descaso & 13 & $6,44 \%$ \\
Futuro & 13 & $6,44 \%$ \\
Irresponsabilidade & 11 & $5,45 \%$ \\
Morte & 11 & $5,45 \%$ \\
Educação & 6 & $2,97 \%$ \\
Impacto ambiental & 5 & $2,48 \%$ \\
Política & 5 & $2,48 \%$ \\
Qualidade de vida & 5 & $2,48 \%$ \\
Conscientização & 4 & $1,98 \%$ \\
Desequilíbrio ambiental & 4 & $1,98 \%$ \\
Efeito estufa & 4 & $1,98 \%$ \\
Desperdício & 3 & $1,49 \%$ \\
Lixo & 3 & $1,49 \%$ \\
Sustentabilidade & 3 & $1,49 \%$ \\
Tristeza & 3 & $1,49 \%$ \\
Não respondeu & 1 & $0,50 \%$ \\
\hline & &
\end{tabular}

As respostas apontadas nas TAB. 32 e 33 demonstram que a maioria de $90,32 \%$ apresentou uma visão negativa nas associações feitas ao termo degradação ambiental, a poluição foi a mais citada com 18,81\%, o desmatamento, a extinção e as mudanças climáticas também foram apontadas com frequência.

Paralelamente, possíveis soluções e atitudes foram citadas pelos entrevistados, indicando que incentivos em educação e conscientização (4,95\%) podem auxiliar na minimização da degradação ambiental.

\subsubsection{Benefícios e riscos}

Foram apresentados nove itens e solicitado ao entrevistado que apontasse, caso houvesse, seus riscos e benefícios. Lembrando que todas as atividades apresentadas neste estudo apresentam riscos e benefícios.

Os questionários $\mathrm{n}^{\circ} 63,84,94,102,106,113,114,126,152,181 \mathrm{e}$ 195, foram excluídos desta avaliação, pois estavam sem respostas. Portanto 
restaram 213 questionários que foram avaliados de acordo com o que se segue (FIG. 15 a 32).

\section{1: Hidroelétrica}

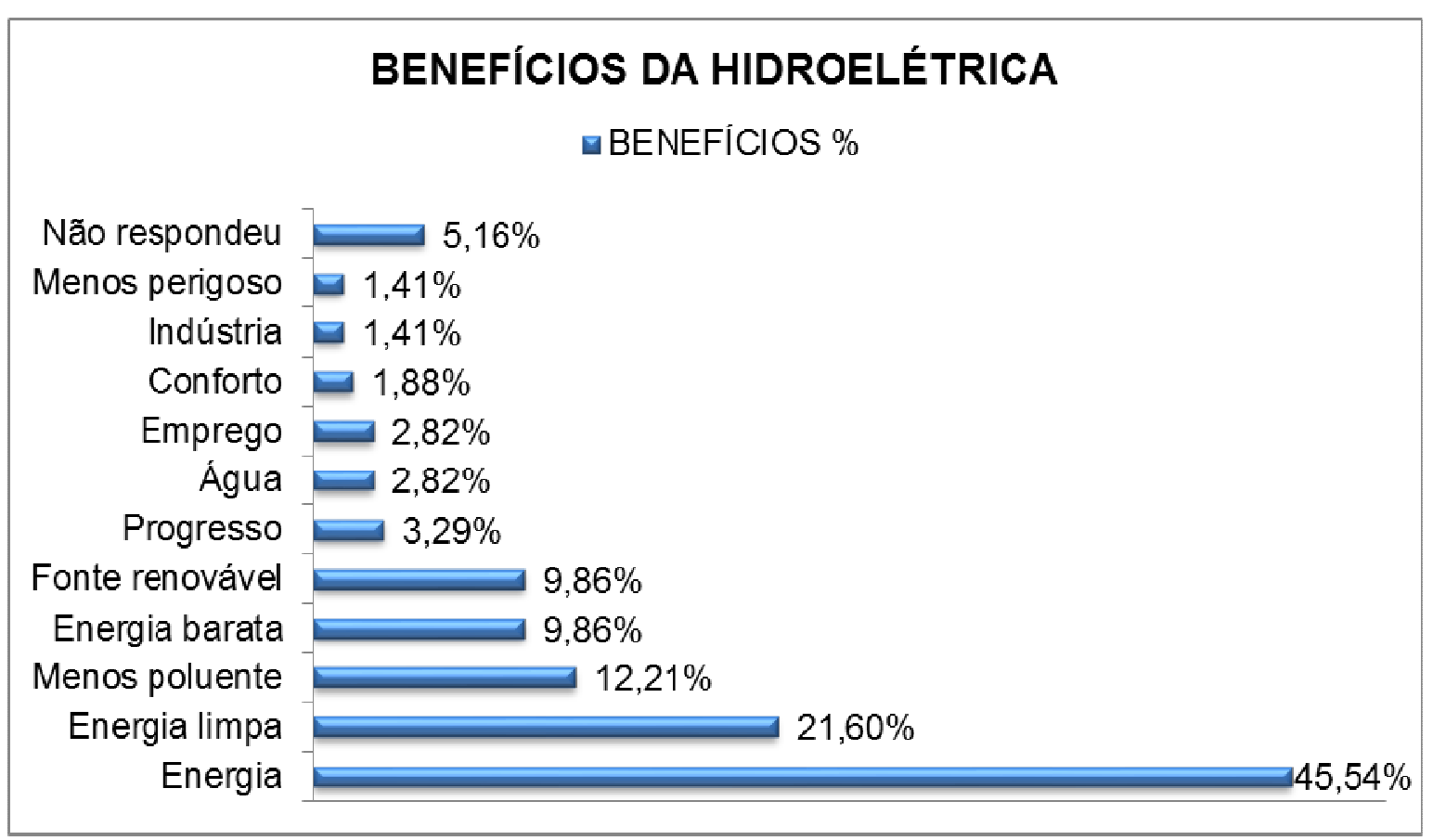

FIGURA 15 - Benefícios apontados para a hidroelétrica

Os benefícios mais apontados (FIG. 15) para a hidroelétrica estão associados à produção de energia $(45,54 \%)$, com as variantes limpa $(21,60 \%)$, menos poluente $(12,21 \%)$ e barata $(9,86 \%)$. Sendo que $5,16 \%$ não apontaram respostas, indicando a possibilidade de não existirem benefícios. 


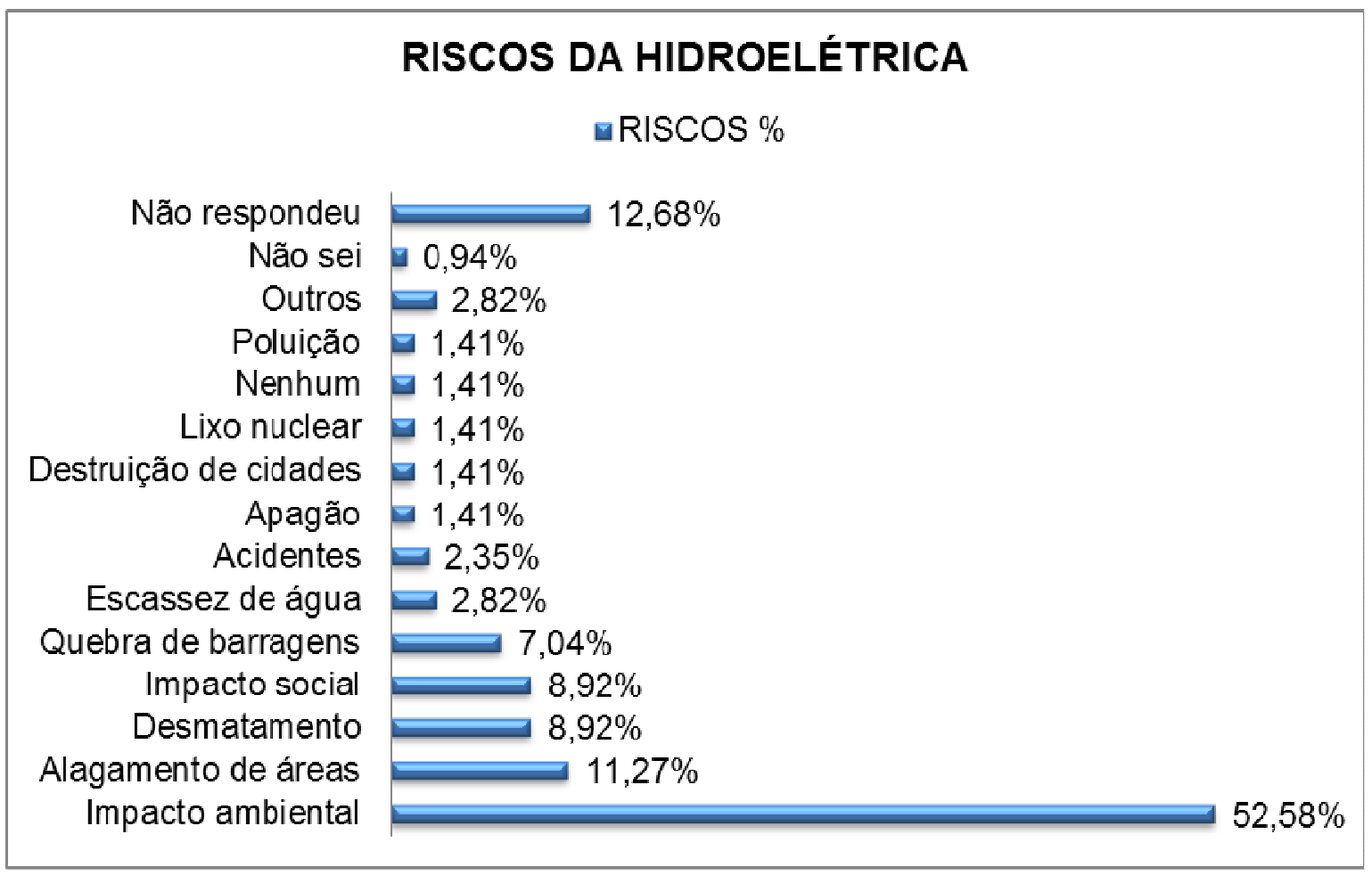

FIGURA 16 - Riscos apontados para a hidroelétrica

Dentre os riscos apontados na FIG. 16, o impacto ambiental foi indicado por $52,58 \%$, especificamente os identificadores alagamento de áreas $(11,27 \%)$, desmatamento $(8,92 \%)$ e quebra de barragens $(7,04)$ também foram citados. O identificador outros $(2,82 \%)$, inclui os identificadores, alto custo, ecossistema, falta de manutenção e morte. Sendo que $12,68 \%$ não apontaram respostas, indicando a possibilidade de não existirem riscos. 
2: Veículos automotivos

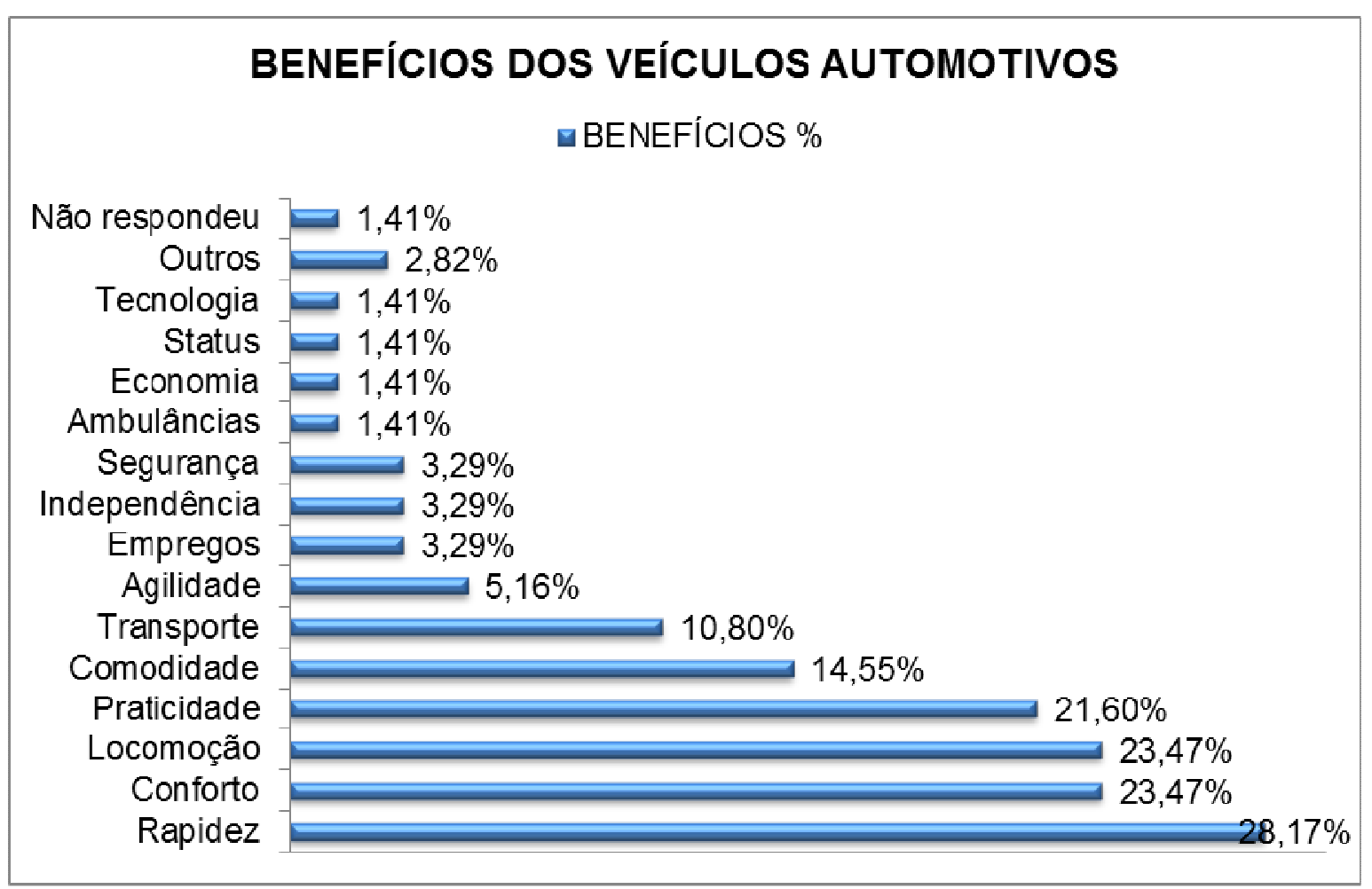

FIGURA 17 - Benefícios apontados para os veículos automotivos

Os benefícios mais apontados (FIG. 17) para os veículos automotivos estão a rapidez (28,17\%), conforto e locomoção (ambos com $23,47 \%$ ), praticidade $(21,60 \%)$ e comodidade $(14,55 \%)$.

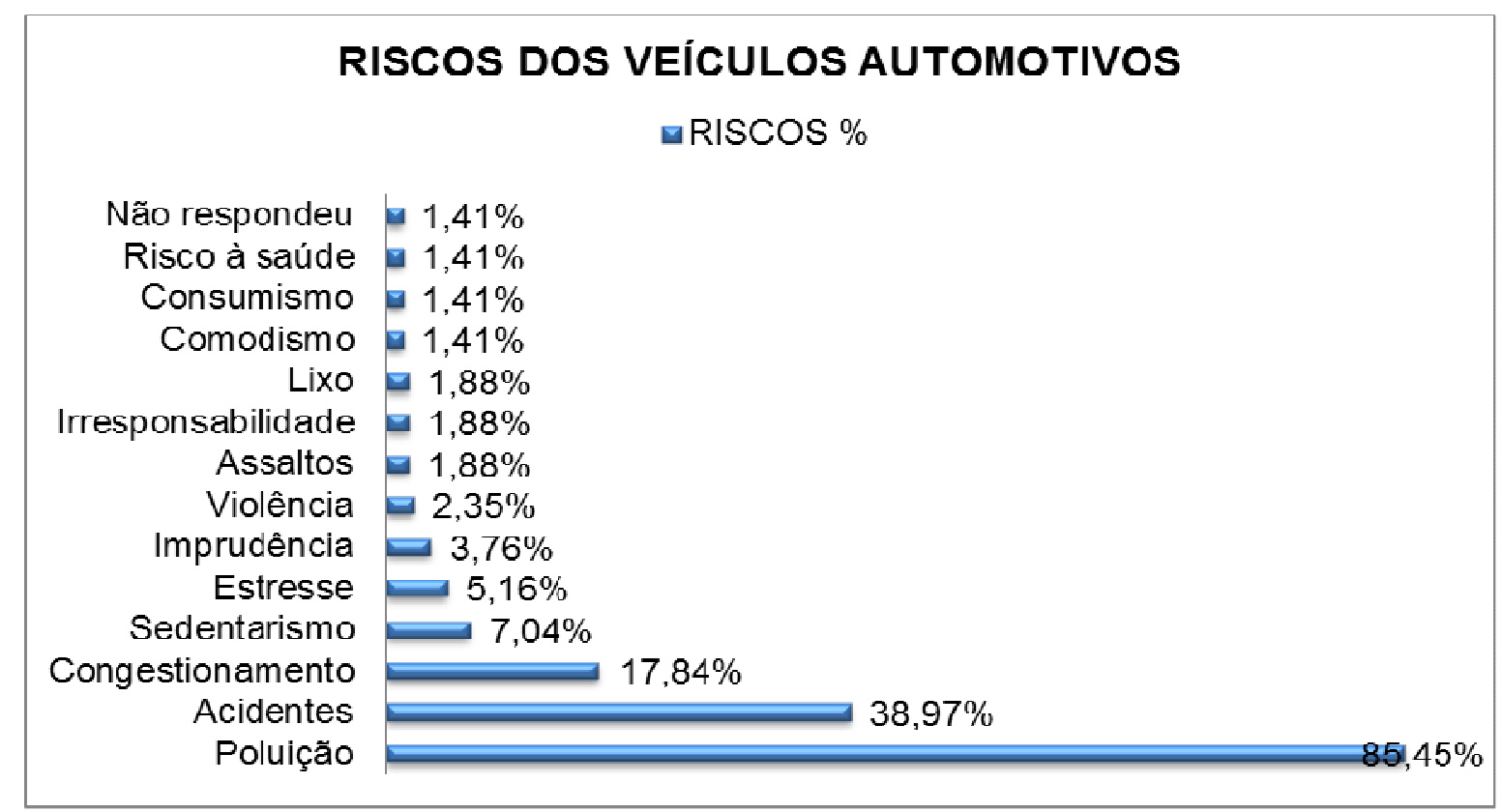

FIGURA 18 - Riscos apontados para os veículos automotivos 
Dentre os riscos apontados na FIG. 18, a poluição foi apontada por $85,45 \%$ dos entrevistados, seguida a distância por acidentes $(38,97)$ e congestionamento $(17,84 \%)$.

\section{3: Indústria química}

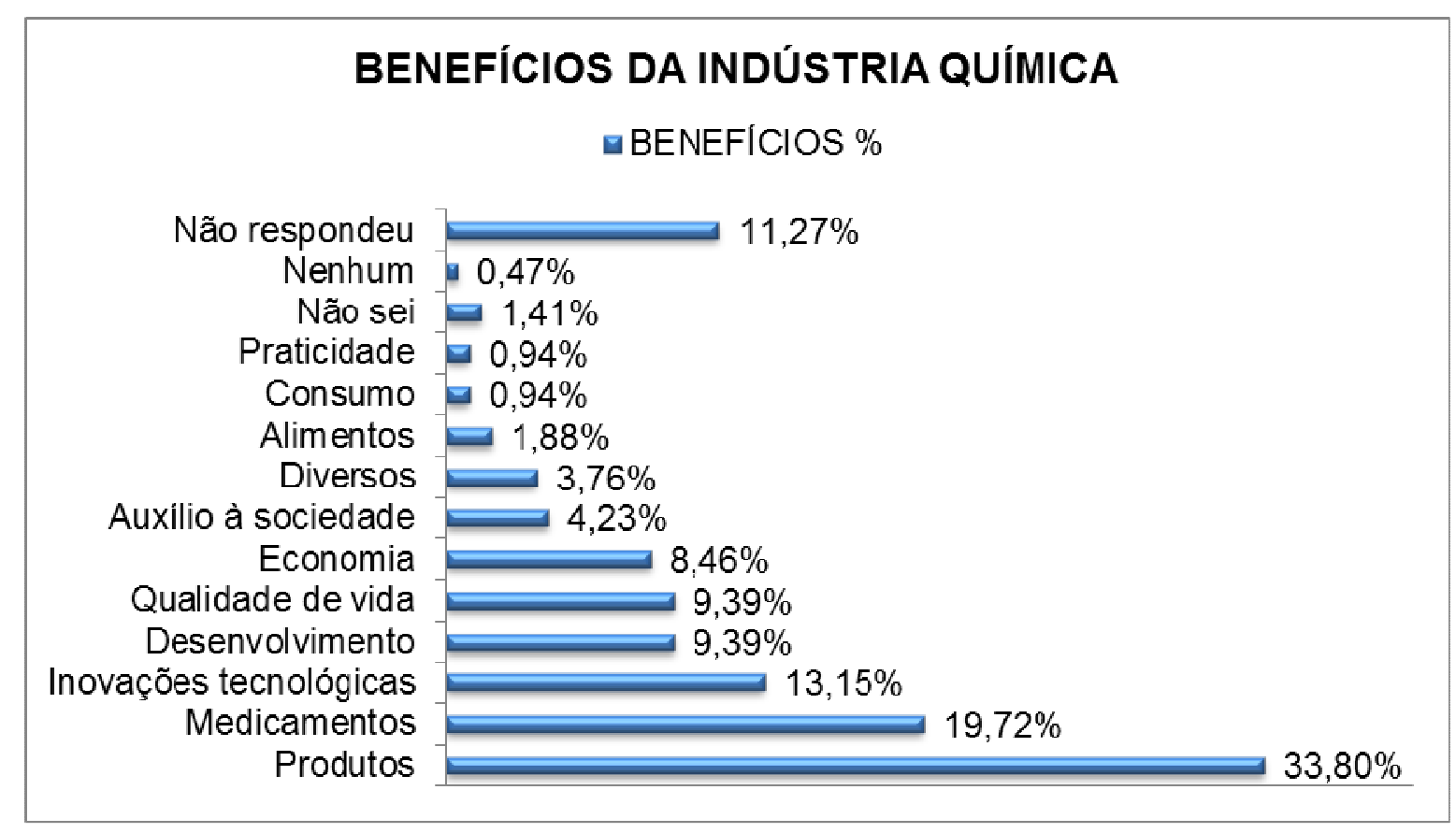

FIGURA 19 - Benefícios apontados para a indústria química

Os benefícios mais apontados (FIG. 19) para a indústria química, estão associados ao desenvolvimento de produtos $(33,80 \%)$ e medicamentos $(19,72 \%)$, inovações tecnológicas $(13,15 \%)$ e desenvolvimento $(9,39 \%)$ também foram apontados. Já $11,27 \%$ não apontaram respostas, indicando a possibilidade de não existirem benefícios. 


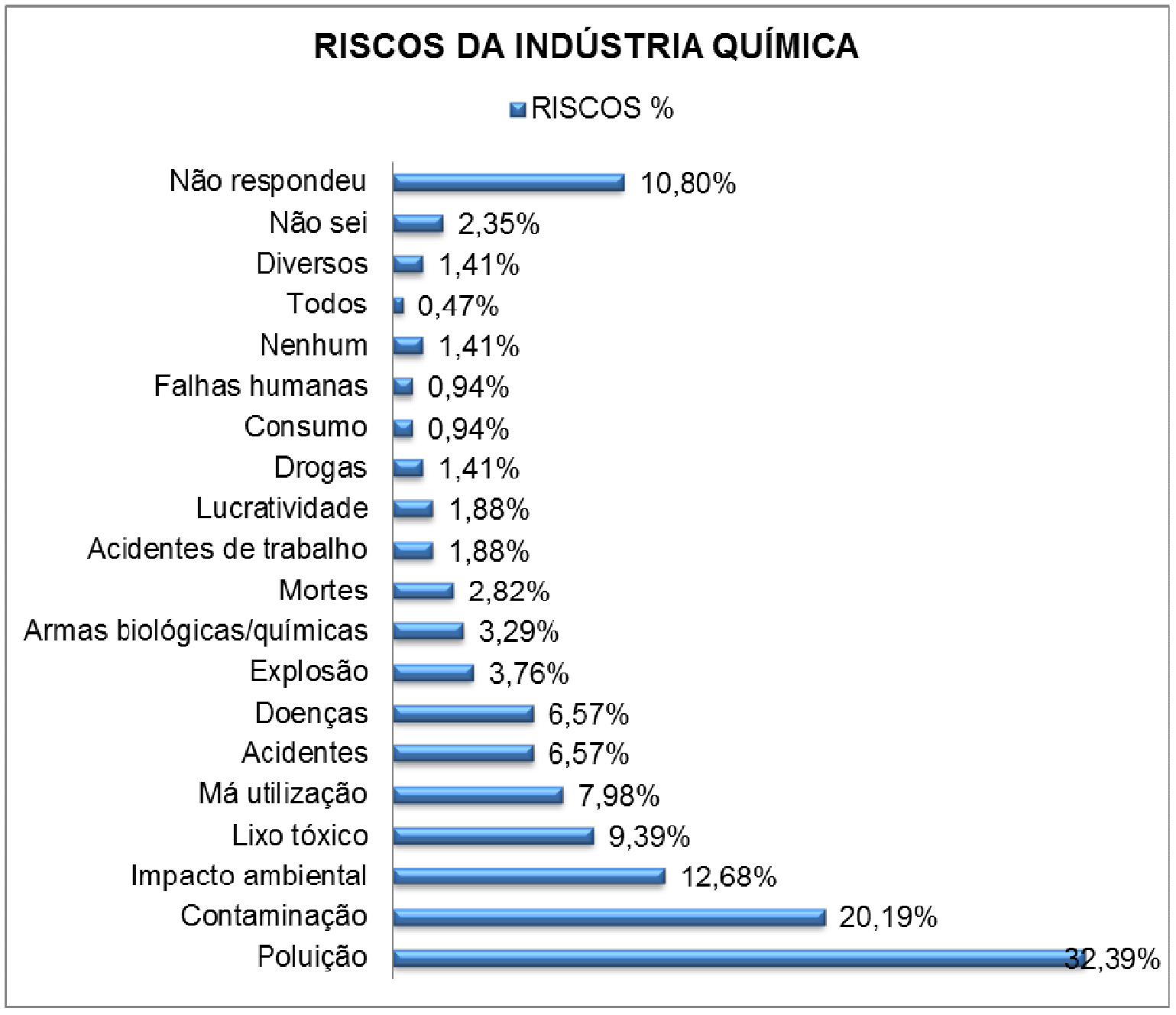

FIGURA 20 - Riscos apontados para a indústria química

Dentre os riscos apontados na FIG. 20 , a poluição $(32,39 \%)$ e a contaminação (20,19\%), tiveram maior frequência. Outro apontamento interessante foram as respostas de nenhum risco $(1,41 \%)$, todos os riscos $(0,47 \%)$ e diversos $(1,41 \%)$. 
4: Novos tratamentos médicos

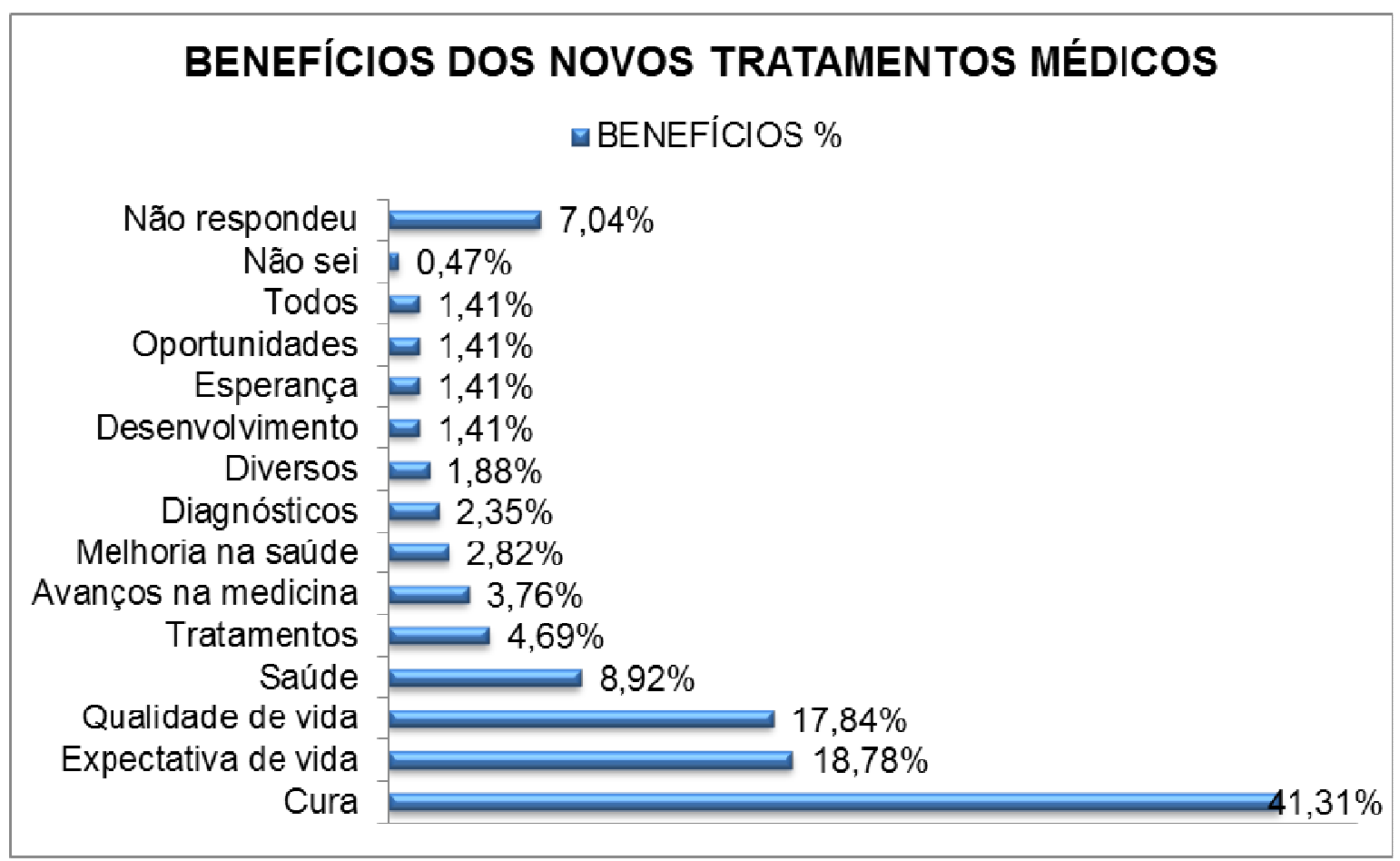

FIGURA 21 - Benefícios apontados para novos tratamentos médicos

A cura apareceu com 41,31\%, e expectativa de vida $(18,78 \%$ ) e qualidade de vida $(17,84 \%)$, o seguiram. Já $7,04 \%$ não apontaram respostas, indicando a possibilidade de não existirem benefícios (FIG. 21). 


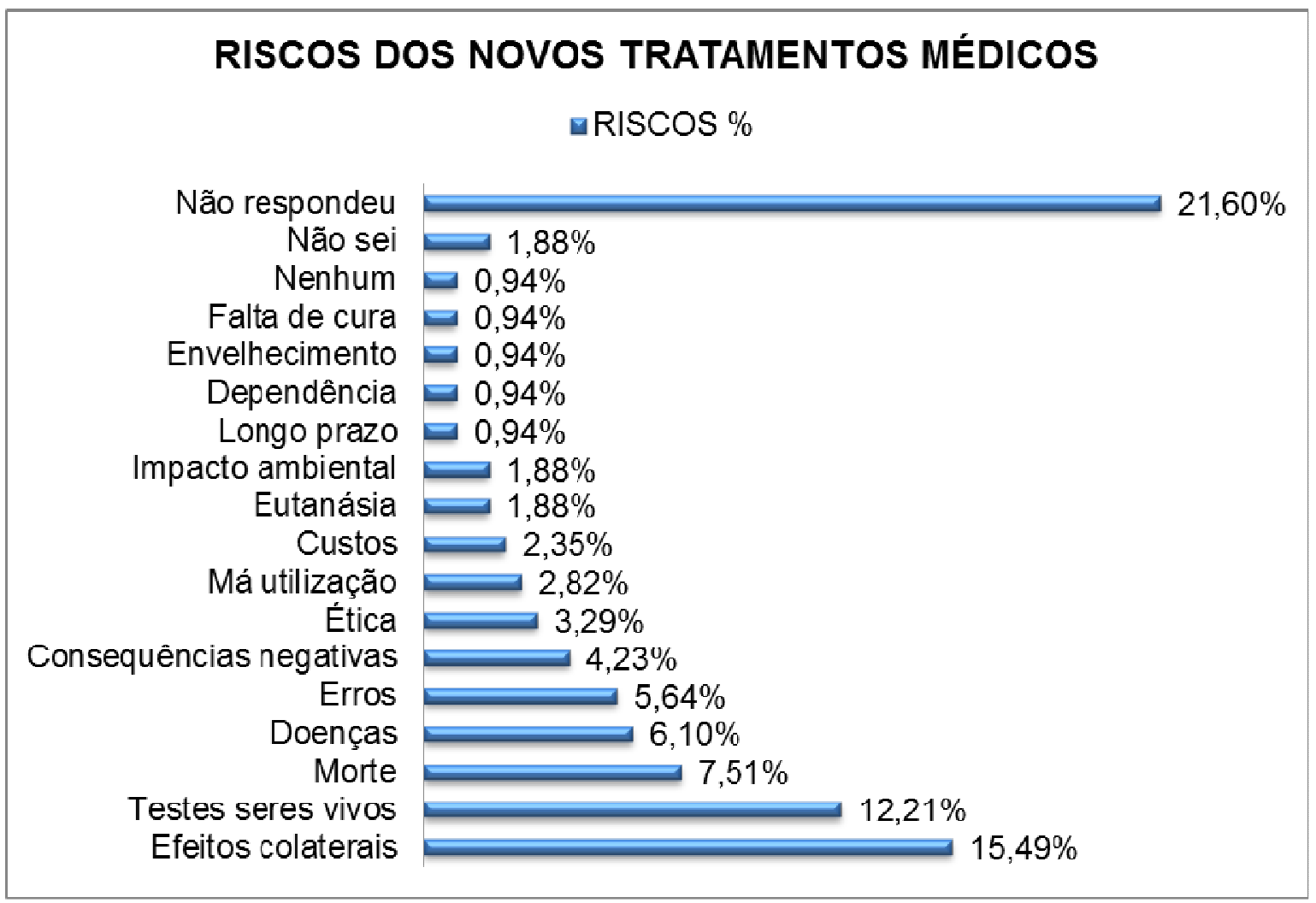

FIGURA 22 - Riscos apontados para novos tratamentos médicos

Dentre os riscos apontados na FIG. 22, 21,60\% não apontaram respostas, indicando a possibilidade de não existirem riscos. Outros apontaram efeito colateral $(15,49 \%)$ e testes em seres vivos $(12,21 \%)$. 


\section{5: Termoelétrica}

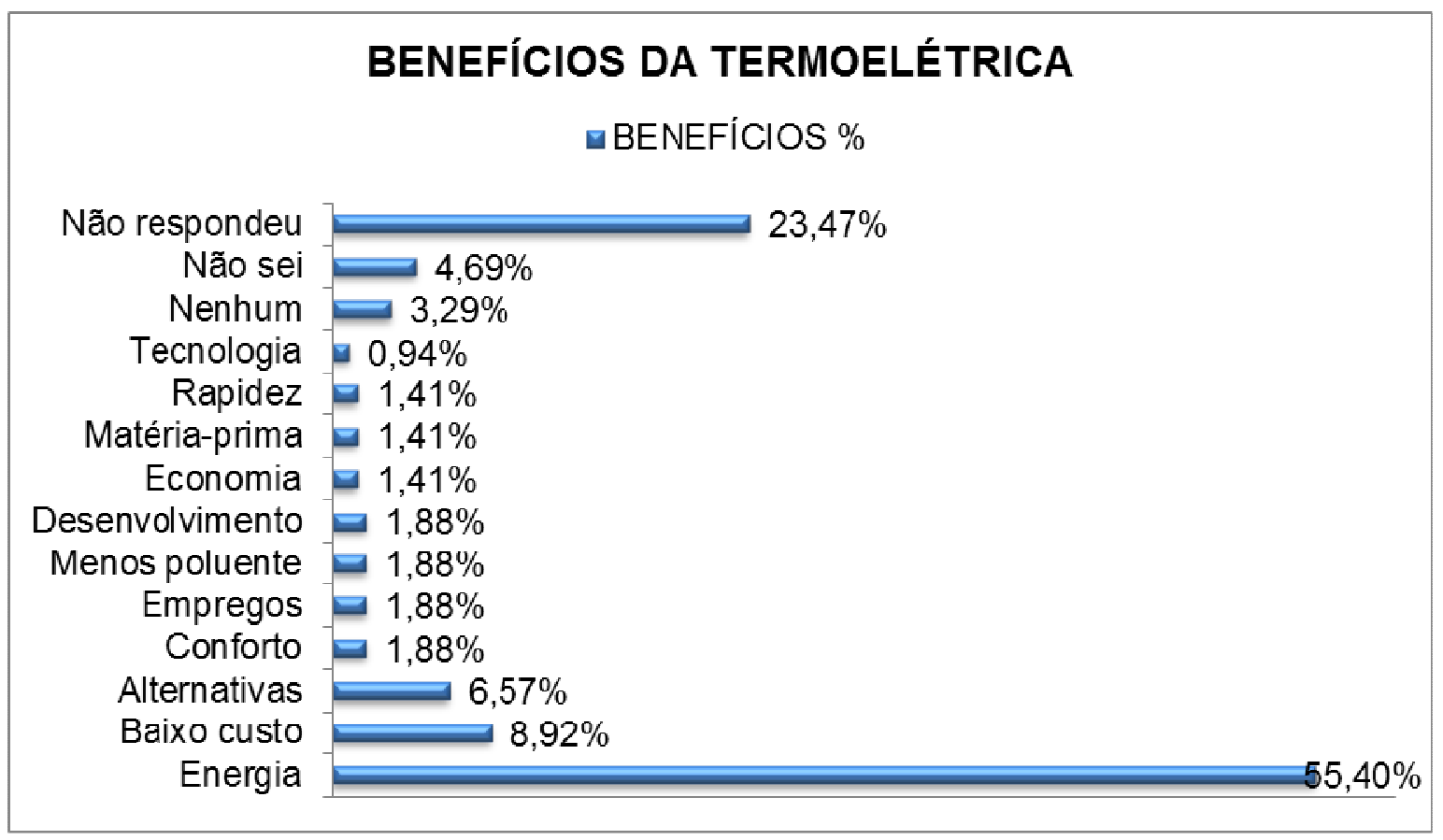

FIGURA 23 - Benefícios apontados para a termoelétrica

Na FIG. 23, a produção de energia, com $55,40 \%$, foi apontada como o maior benefício proporcionado pela termoelétrica. Porém 23,47\% não apontaram respostas, indicando a possibilidade de não existirem benefícios.

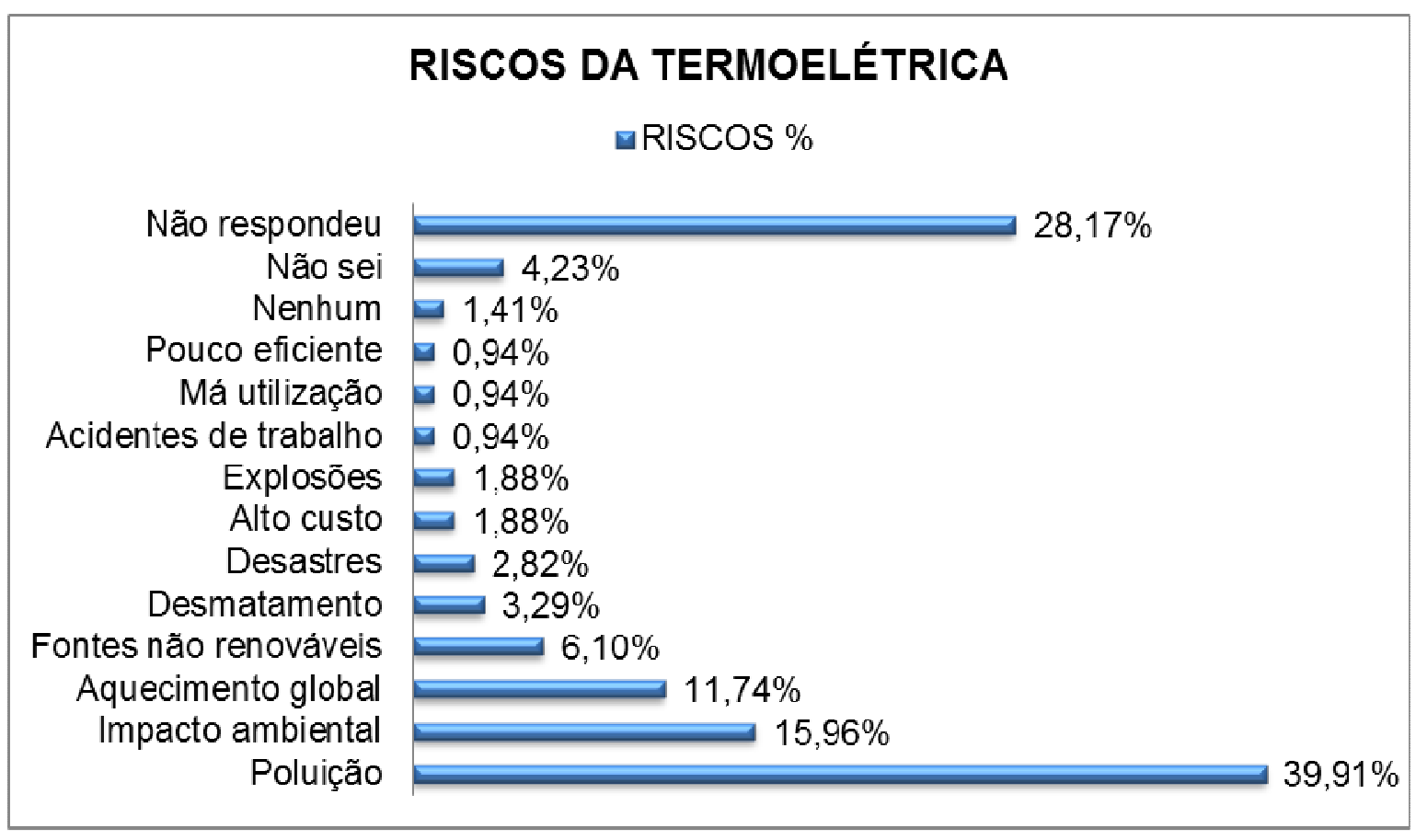

FIGURA 24 - Riscos apontados para a termoelétrica 
Dentre os riscos apontados na FIG. 24, 39,91\% apontaram a poluição e $28,17 \%$ não apontaram respostas, indicando a possibilidade de não existirem riscos, seguidos por impacto ambiental $(15,96 \%)$ e aquecimento global $(11,74 \%)$.

6: Desenvolvimento de novos materiais

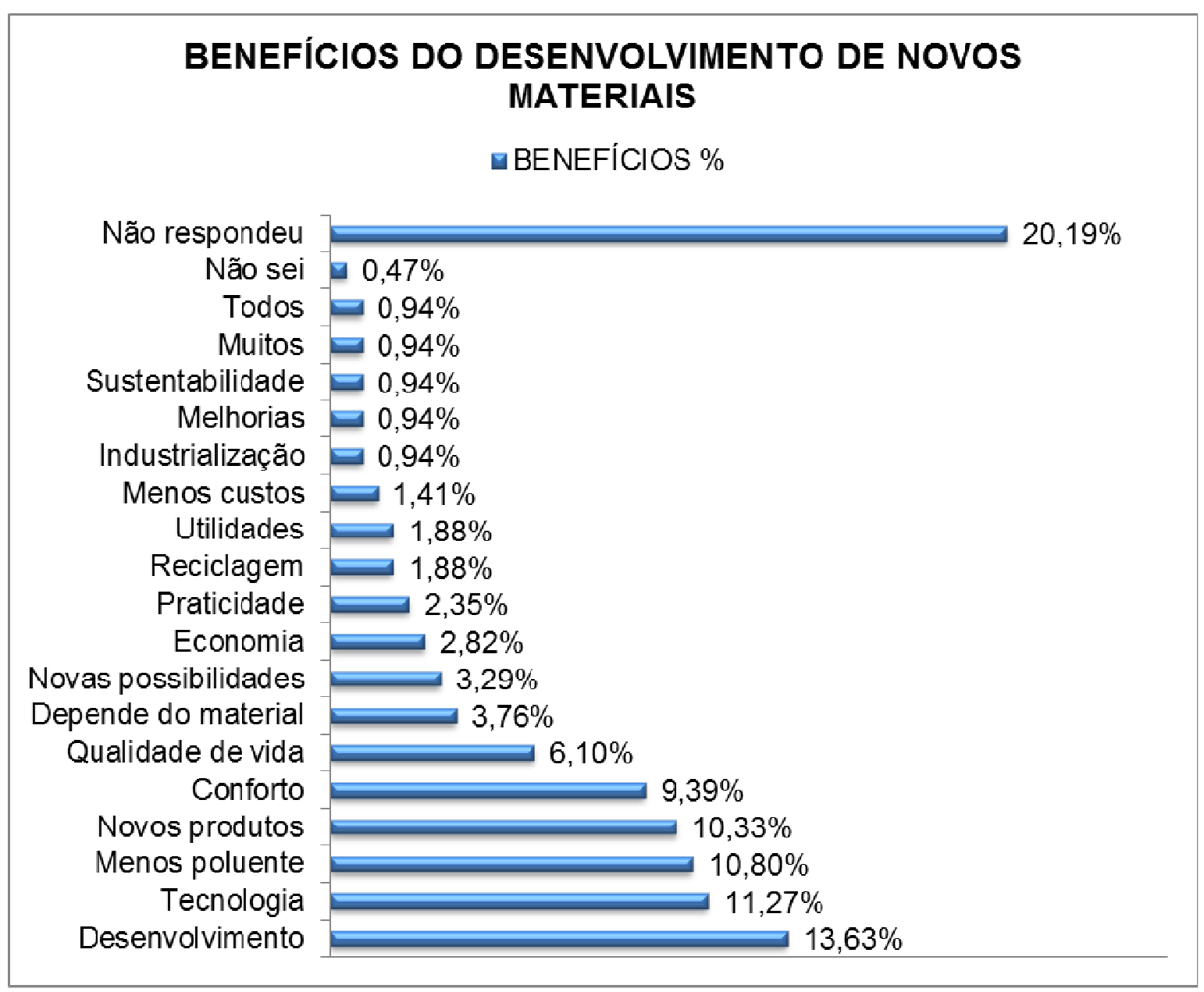

FIGURA 25 - Benefícios apontados para o desenvolvimento de novos materiais

Dentre os benefícios apontados na FIG. 25, 20,19\% não apontaram respostas, indicando a possibilidade de não existirem benefícios. Outros apontaram desenvolvimento (13,63\%) e tecnologia $(11,27 \%)$. 


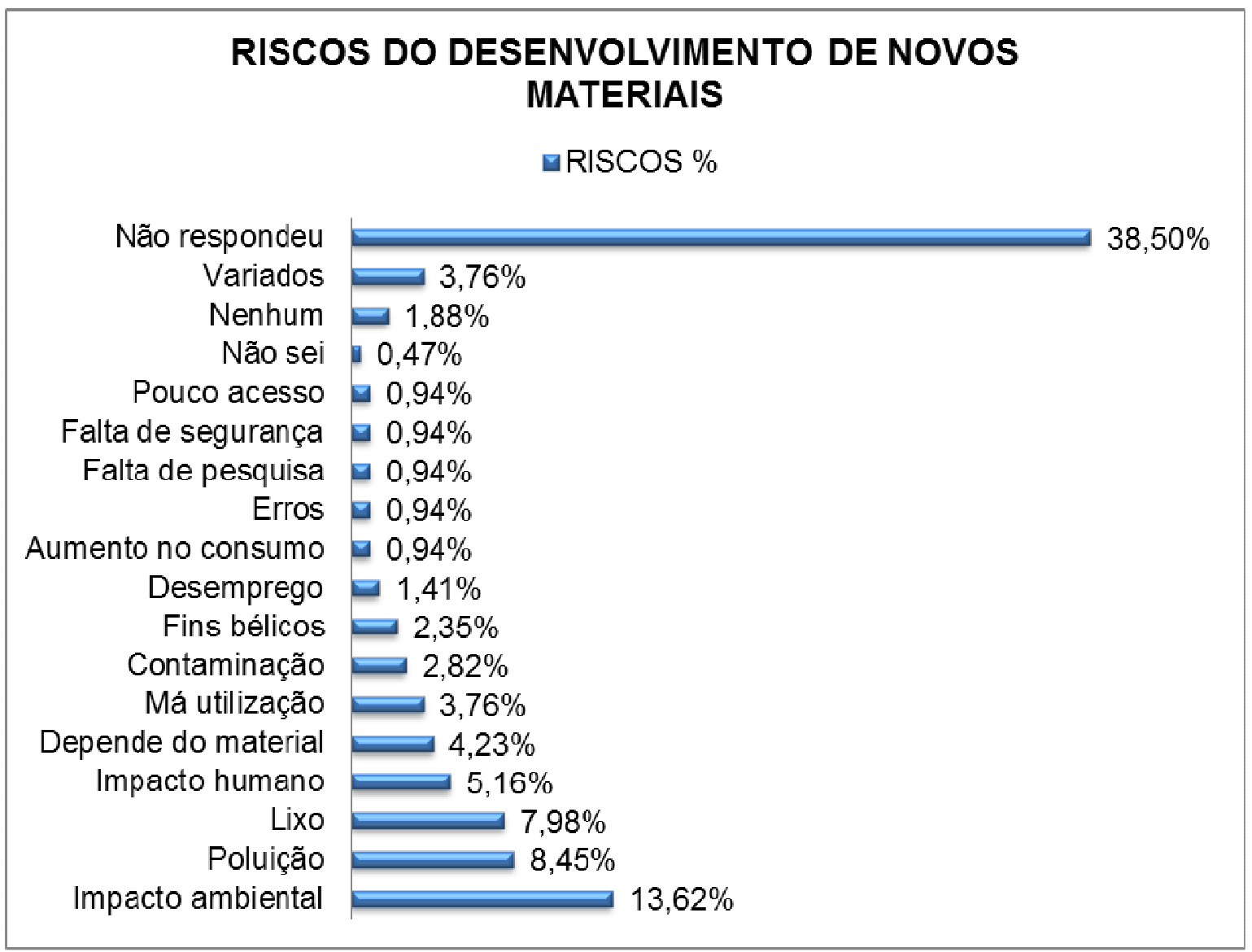

FIGURA 26 - Riscos apontados para o desenvolvimento de novos materiais

Dentre os riscos apontados na FIG. 26, 38,50\% não apontaram respostas, indicando a possibilidade de não existirem riscos, seguidos por impacto ambiental $(13,62 \%)$ e poluição $(8,45 \%)$. 


\section{7: Radioterapia}

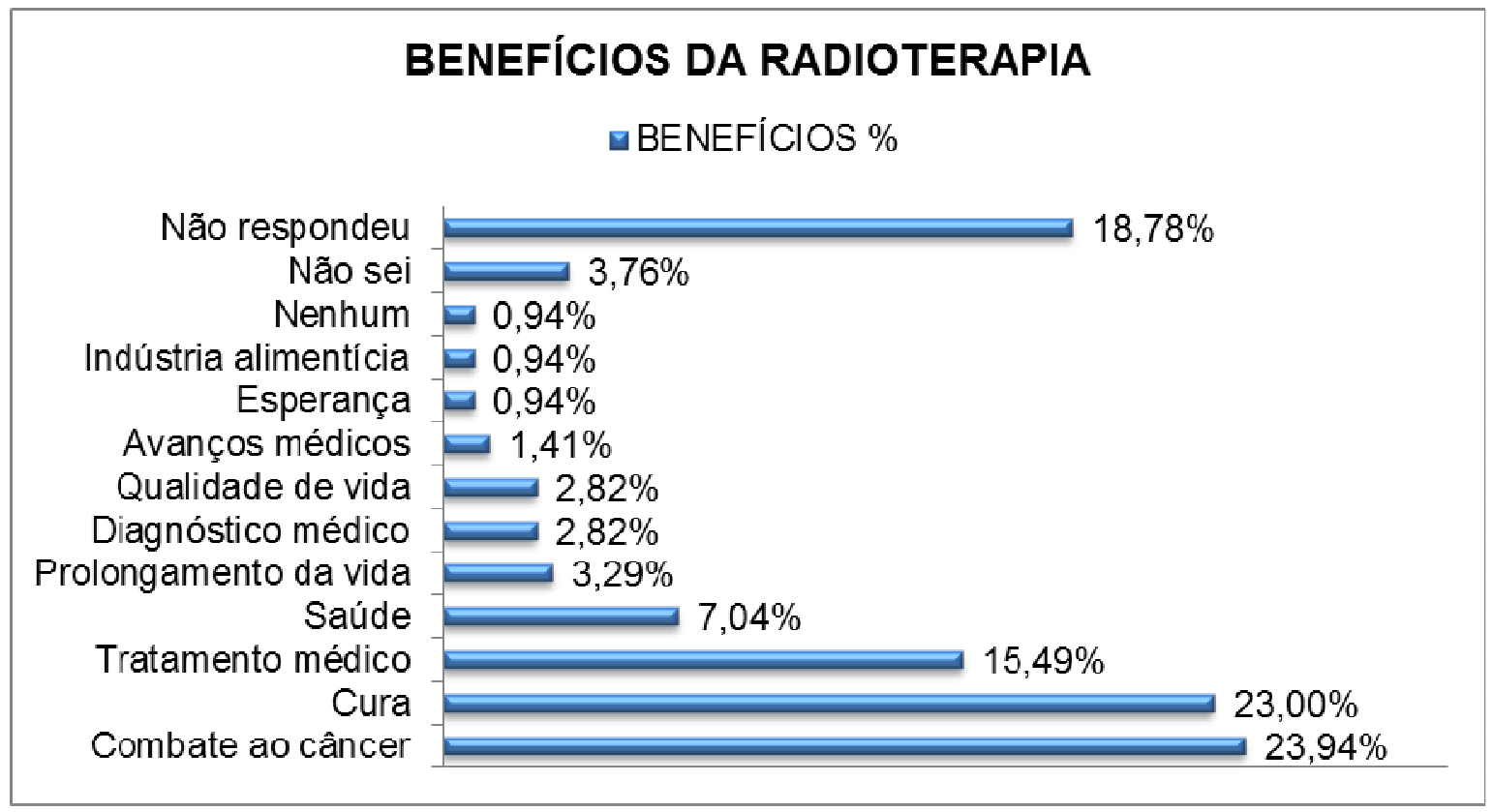

FIGURA 27 - Benefícios apontados para a radioterapia

Os benefícios mais apontados (FIG. 27) para a radioterapia, estão associados ao combate ao câncer (23,94\%), a cura (23,00\%). Sendo que $18,78 \%$ não apontaram respostas, indicando a possibilidade de não existirem benefícios.

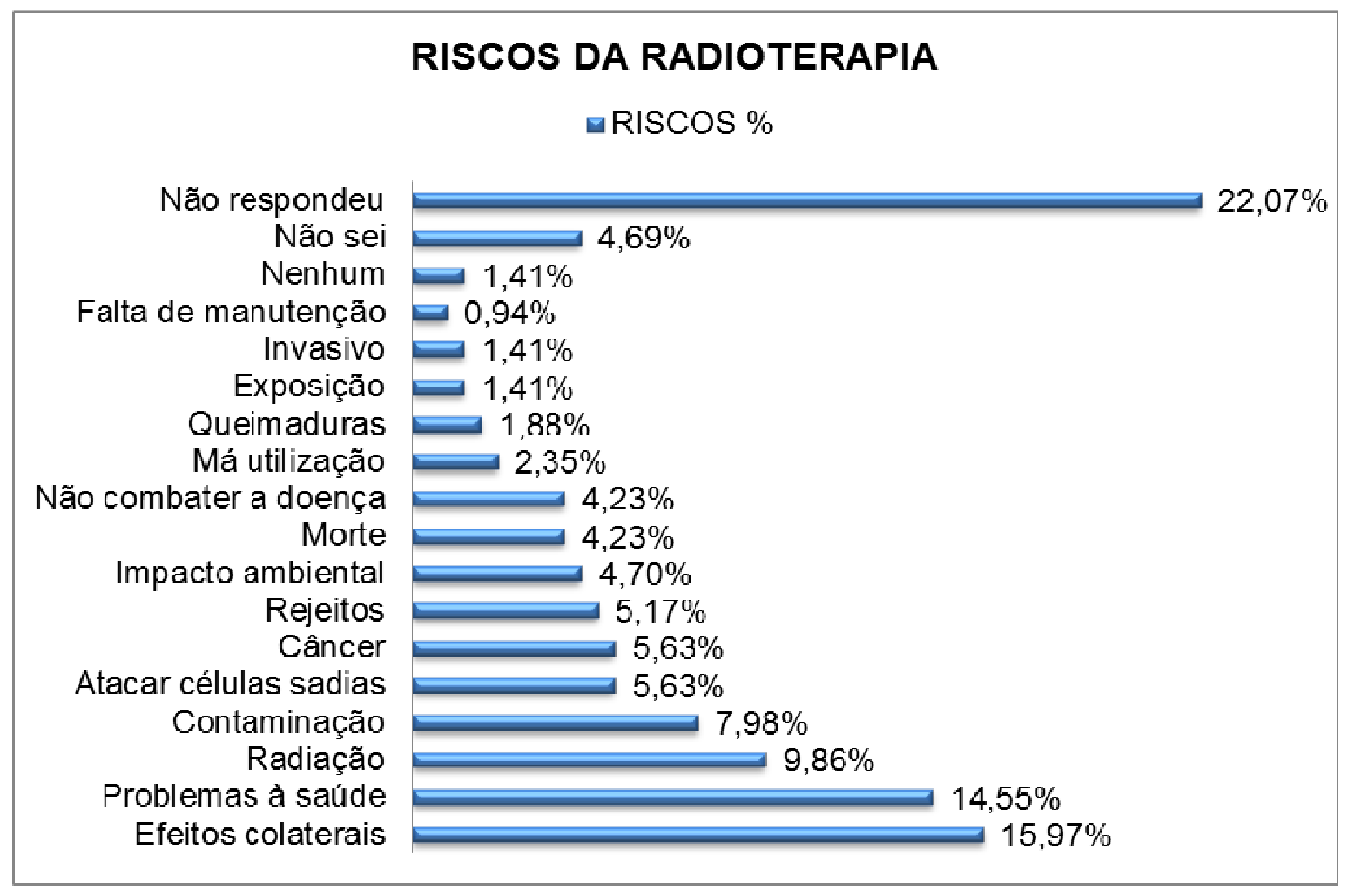

FIGURA 28 - Riscos apontados para a radioterapia 
Dentre os riscos apontados na FIG. 28, 22,07\% não apontaram respostas, indicando a possibilidade de não existirem riscos. Seguidos por $15,97 \%$ que apontaram os efeitos colaterais e 14,55\%, com problemas à saúde.

\section{8: Soja transgênica}

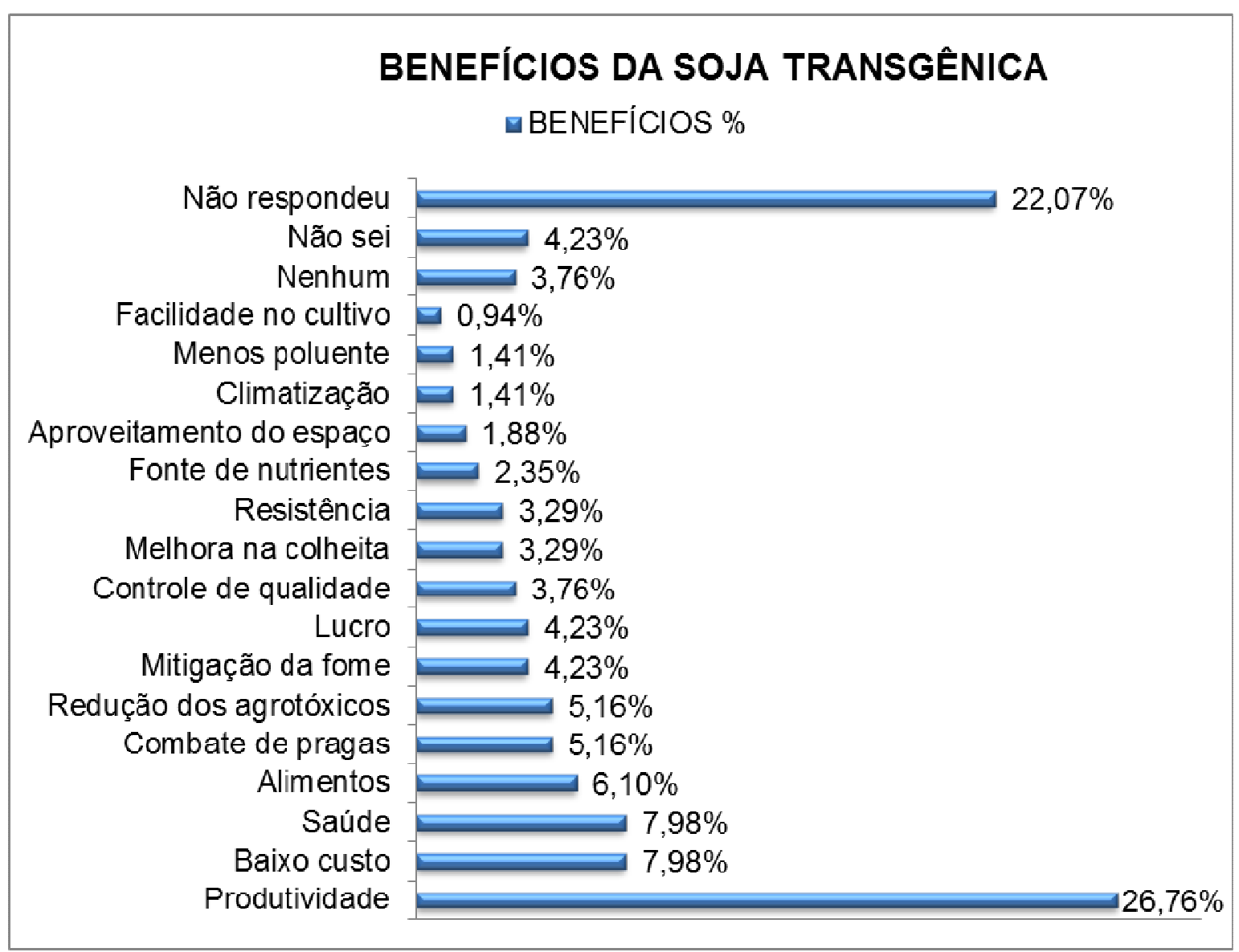

FIGURA 29 - Benefícios apontados para a soja transgênica

Os benefícios mais apontados (FIG. 29) para a soja transgênica estão associados a produtividade com $26,76 \%$, seguido por $22,07 \%$ que não apontaram respostas, indicando a possibilidade de não existirem benefícios. 


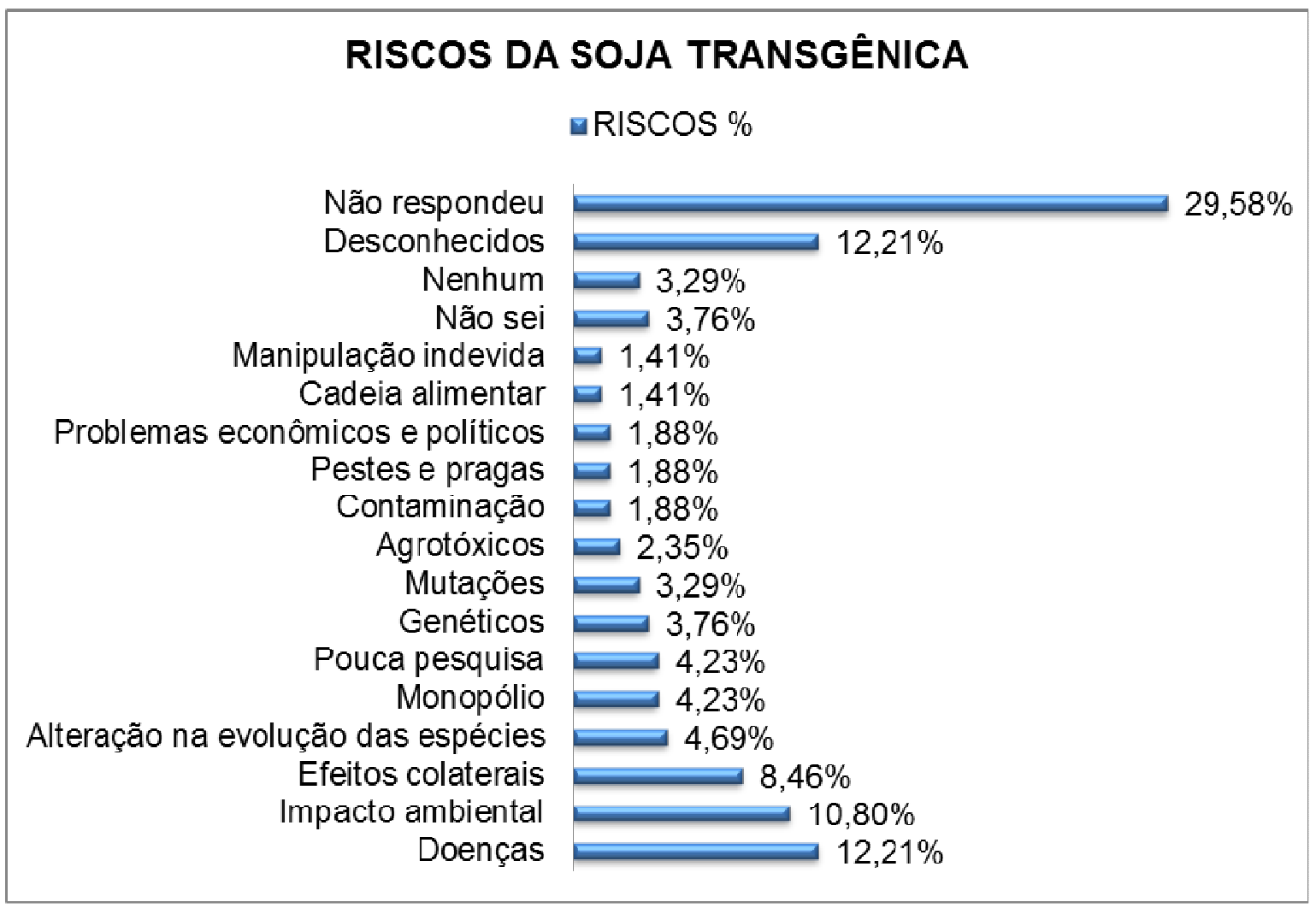

FIGURA 30 - Riscos apontados para a soja transgênica

Dentre os riscos apontados na FIG. 30, 29,58\% não apontaram respostas, indicando a possibilidade de não existirem riscos. Seguidos por $12,21 \%$ que apontaram riscos desconhecidos, que apontam a falta de conhecimento sobre $o$ assunto. 
9: Reator nuclear de Angra dos Reis

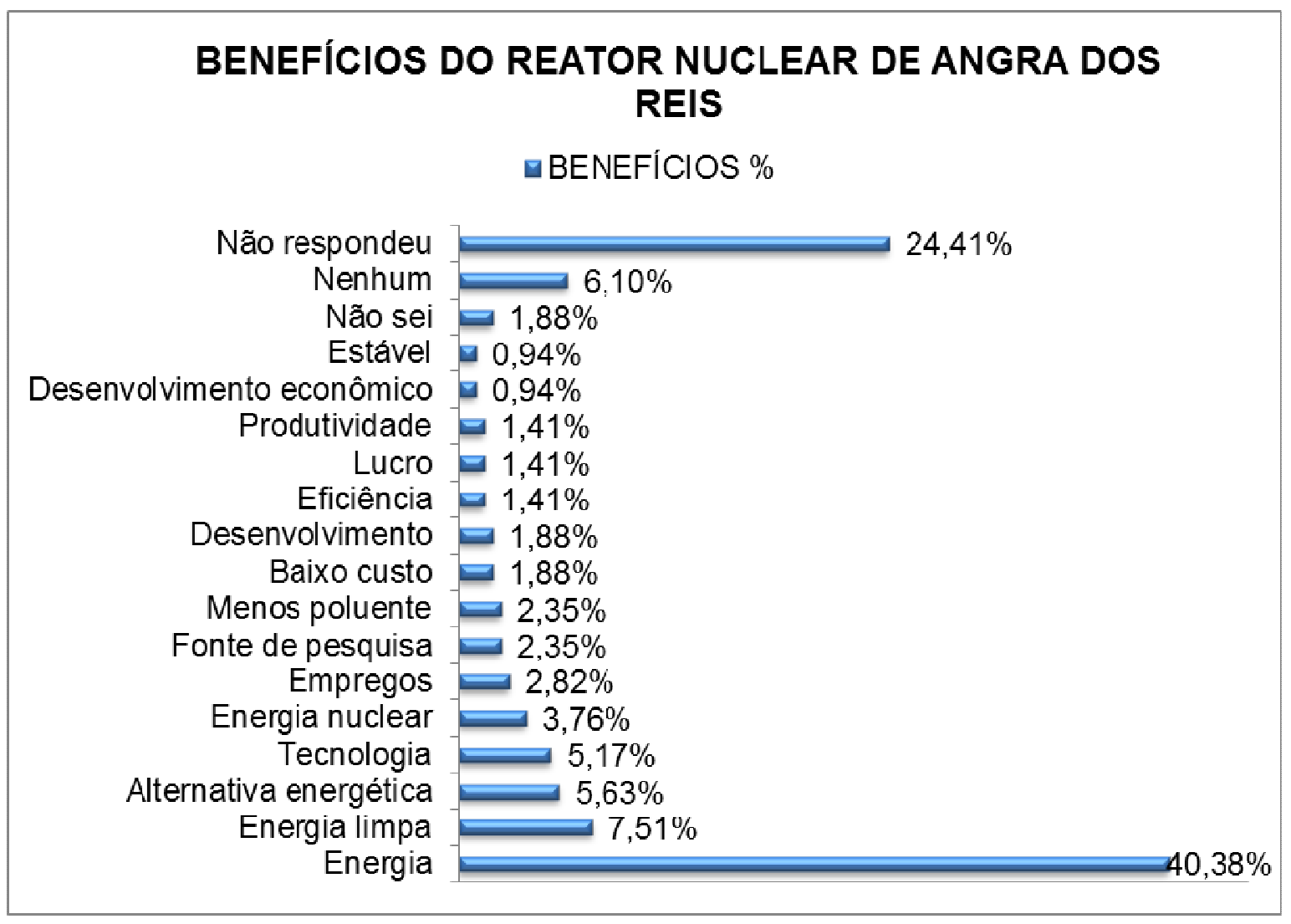

FIGURA 31 - Benefícios apontados para o reator nuclear de Angra dos Reis

O benefício mais apontado (FIG. 31) para o reator nuclear de Angra dos Reis é a produção de energia (40,38\%), associado a energia limpa $(7,51 \%)$. Porém, também aparecem $24,41 \%$ que não apontaram respostas, indicando a possibilidade de não existirem benefícios. 


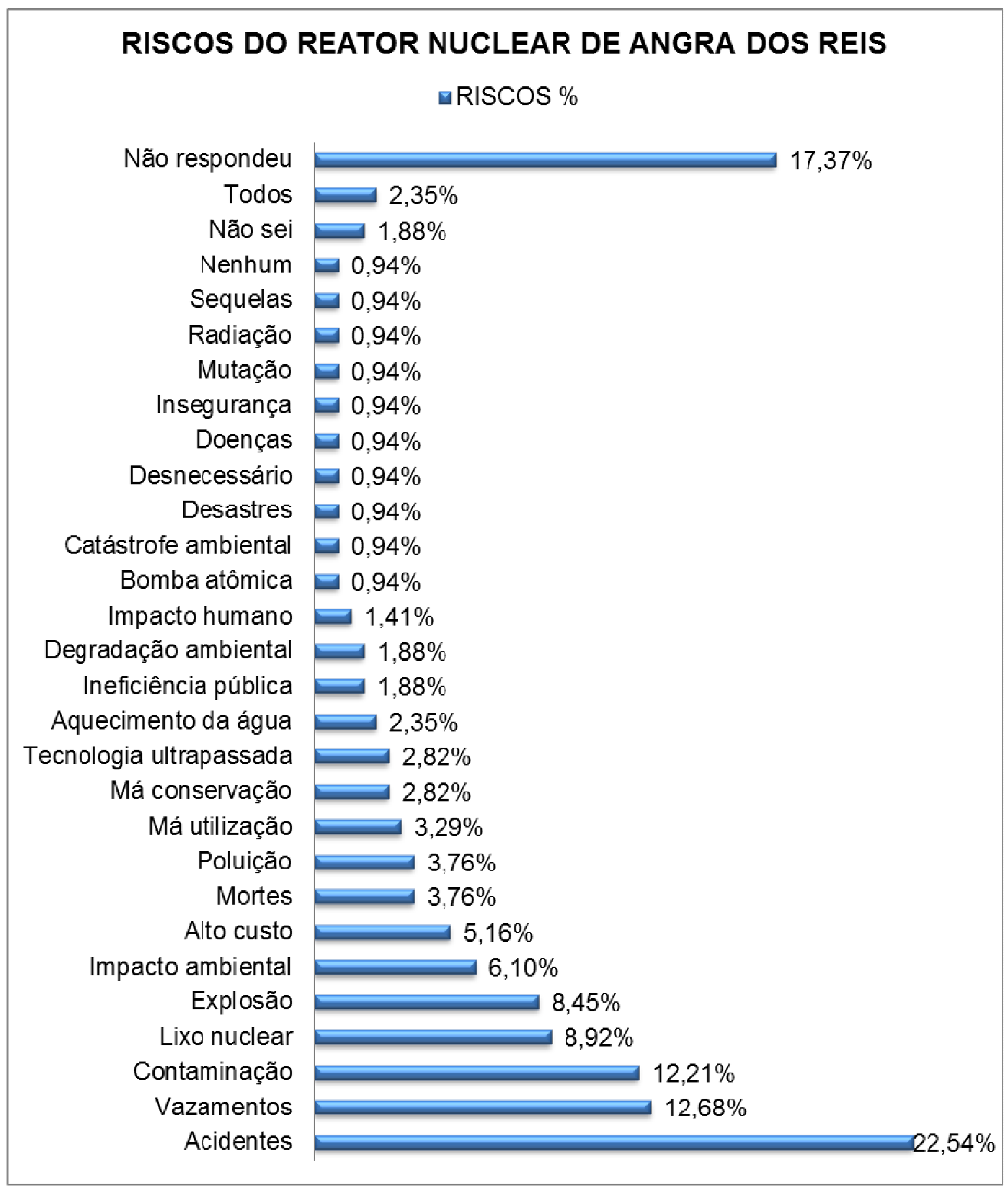

FIGURA 32 - Riscos apontados para o reator nuclear de Angra dos Reis

Dentre os riscos apontados na FIG. 32, 22,54\%, indicaram a possibilidade de acidentes, com vazamentos $(12,68 \%)$ e contaminação $(12,21 \%)$. E $17,37 \%$ não apontaram respostas, indicando a possibilidade de não existirem riscos.

Foram considerados os riscos e benefícios mais apontados pelos entrevistados e estão apresentados na TAB. 34. 
TABELA 34 - Benefícios e riscos mais apontados na pesquisa

\begin{tabular}{|c|c|c|}
\hline ATIVIDADE & BENEFÍCIOS & RISCOS \\
\hline \multirow{2}{*}{ Hidroelétrica } & 1. Energia (46\%) & 1. Impacto ambiental (53\%) \\
\hline & 2. Energia limpa (22\%) & 2. Alagamento de áreas $(11 \%)$ \\
\hline \multirow{2}{*}{ Veículos automotivos } & 1. Rapidez (28\%) & 1. Poluição (85\%) \\
\hline & 2. Conforto $(23 \%)$ & 2. Acidentes (39\%) \\
\hline \multirow{2}{*}{ Indústria química } & 1. Produtos $(34 \%)$ & 1. Poluição (32\%) \\
\hline & 2. Medicamentos (20\%) & 2. Contaminação (20\%) \\
\hline \multirow{2}{*}{ Novos tratamentos médicos } & 1. Cura $(41 \%)$ & 1. Efeitos colaterais $(15 \%)$ \\
\hline & 2. Expectativa de vida (19\%) & 2. Testes em seres vivos $(12 \%)$ \\
\hline \multirow{2}{*}{ Termoelétrica } & 1. Energia $(55 \%)$ & 1. Poluição (40\%) \\
\hline & 2. Baixo custo $(9 \%)$ & 2. Impacto ambiental (16\%) \\
\hline $\begin{array}{l}\text { Desenvolvimento de } \\
\text { novos materiais }\end{array}$ & $\begin{array}{l}\text { 1. Desenvolvimento }(14 \%) \\
\text { 2. Tecnologia }(11 \%)\end{array}$ & $\begin{array}{l}\text { 1. Impacto ambiental }(14 \%) \\
\text { 2. Poluição }(8 \%)\end{array}$ \\
\hline \multirow{2}{*}{ Radioterapia } & 1. Combate ao câncer $(24 \%)$ & 1. Efeitos colaterais $(16 \%)$ \\
\hline & 2. Cura $(23 \%)$ & 2. Problemas à saúde (15\%) \\
\hline \multirow{2}{*}{ Soja transgênica } & 1. Produtividade $(27 \%)$ & 1. Doenças (12\%) \\
\hline & 2. Baixo custo $(8 \%)$ & 2. Impacto ambiental (11\%) \\
\hline Reator nuclear de & 1. Energia (40\%) & 1. Acidentes $(23 \%)$ \\
\hline Angra dos Reis & 2. Energia limpa (8\%) & 2. Vazamentos (13\%) \\
\hline
\end{tabular}

A produção de energia foi apontada como o maior benefício em três das atividades: hidroelétrica (46\%); termoelétrica (55\%); e reator nuclear $(40 \%)$. Em duas aparece associada no termo energia limpa: hidroelétrica (22\%); e reator nuclear $(8 \%)$.

No apontamento dos riscos, o mesmo ocorreu com o termo impacto ambiental, apontado em três das atividades: hidroelétrica (53\%); termoelétrica $(16 \%)$; e soja transgênica $(11 \%)$.

\subsubsection{Comparativo entre os riscos: energia nuclear e degradação ambiental}

Foi solicitado ao entrevistado que pensasse no risco associado à energia nuclear e à degradação ambiental e que os classificassem nas dimensões apresentadas. Para a avaliação final foram considerados somente os extremos das dimensões.

\section{Risco: energia nuclear}

Os questionários $\mathrm{n}^{\circ} 52,62,63,73,80,84,94,97,126,178$ e 196, foram excluídos desta avaliação, pois estavam sem respostas. Portanto restaram 213 questionários que foram avaliados de acordo com o que se segue (TAB. 35). 


\section{Risco: degradação ambiental}

Os questionários $n^{\circ} 8,62,63,73,80,84,94,97,126,178,196$ e 226, foram excluídos desta avaliação, pois estavam sem respostas. Portanto restaram 212 questionários que foram avaliados de acordo com o que se segue (TAB. 35).

TABELA 35 - Comparativo entre os riscos da energia nuclear e da degradação ambiental

\begin{tabular}{|c|c|c|c|}
\hline \multicolumn{2}{|c|}{ ENERGIA NUCLEAR } & \multicolumn{2}{|c|}{ AMBIENTAL } \\
\hline \multicolumn{2}{|c|}{ Exposição ao risco } & \multicolumn{2}{|c|}{ Exposição ao risco } \\
\hline Voluntária & Involuntária & Voluntária & Involuntária \\
\hline 17 & 119 & 65 & 82 \\
\hline $7,98 \%$ & $55,87 \%$ & $30,66 \%$ & $38,68 \%$ \\
\hline \multicolumn{2}{|c|}{ Efeito } & \multicolumn{2}{|c|}{ Efeito } \\
\hline Rápido & Lento & Rápido & Lento \\
\hline 69 & 49 & 47 & 68 \\
\hline $32,39 \%$ & $23,00 \%$ & $22,17 \%$ & $32,08 \%$ \\
\hline \multicolumn{2}{|c|}{ Conhecimento para o público } & \multicolumn{2}{|c|}{ Conhecimento para o público } \\
\hline Conhecido & Desconhecido & Conhecido & Desconhecido \\
\hline 21 & 127 & 98 & 36 \\
\hline $9,86 \%$ & $59,62 \%$ & $46,23 \%$ & $16,98 \%$ \\
\hline \multicolumn{2}{|c|}{ Conhecimento para a ciência } & \multicolumn{2}{|c|}{ Conhecimento para a ciência } \\
\hline Conhecido & Desconhecido & Conhecido & Desconhecido \\
\hline 123 & 19 & 152 & 15 \\
\hline $57,75 \%$ & $8,92 \%$ & $71,70 \%$ & $7,08 \%$ \\
\hline \multicolumn{2}{|c|}{ Controle do risco } & \multicolumn{2}{|c|}{ Controle do risco } \\
\hline Controlável & Incontrolável & Controlável & Incontrolável \\
\hline 44 & 60 & 65 & 59 \\
\hline $20,66 \%$ & $28,17 \%$ & $30,66 \%$ & $27,83 \%$ \\
\hline \multicolumn{2}{|c|}{ Tempo do risco } & \multicolumn{2}{|c|}{ Tempo do risco } \\
\hline Novo & Antigo & Novo & Antigo \\
\hline 18 & 105 & 9 & 151 \\
\hline $8,45 \%$ & $49,30 \%$ & $4,25 \%$ & $71,23 \%$ \\
\hline \multicolumn{2}{|c|}{ Medo } & \multicolumn{2}{|c|}{ Medo } \\
\hline Assustador & Pouco assustador & Assustador & Pouco assustador \\
\hline 134 & 23 & 152 & 20 \\
\hline $62,91 \%$ & $10,80 \%$ & $71,70 \%$ & $9,43 \%$ \\
\hline \multicolumn{2}{|c|}{ Exposição ao risco } & \multicolumn{2}{|c|}{ Exposição ao risco } \\
\hline Muitas pessoas & Poucas pessoas & Muitas pessoas & Poucas pessoas \\
\hline 98 & 36 & 175 & 13 \\
\hline $46,01 \%$ & $16,90 \%$ & $82,55 \%$ & $6,13 \%$ \\
\hline
\end{tabular}

Conforme demonstrado na TAB. 35, apesar de a energia nuclear ser considerada pela maioria como desconhecido para o público, com 59,62\%, ao contrário da degradação ambiental (16,98\%), a energia nuclear é considerada menos assustadora que a degradação ambiental, apresentando $62,91 \%$, contra 
$71,70 \%$. A maioria também considera o risco da energia nuclear incontrolável, ao contrário da degradação ambiental considerado controlável. Uma resposta significativa está na abrangência, os riscos ambientais são vistos como capazes de afetar muito mais pessoas.

Com relação à exposição ao risco em ambos os casos foi considerada pela maioria como involuntária. Já a questão do efeito para a energia nuclear foi considerado rápido e para degradação ambiental lento.

Portanto com relação ao conhecimento existente sobre os dois tipos de risco, a TAB. 35 demonstra que ambos são riscos conhecidos para a ciência, já o público possui menos conhecimento sobre os riscos advindos da energia nuclear em comparação com os da degradação ambiental. Ambos também foram considerados como riscos antigos, sobre os quais se tem acumulado conhecimento científico. E também a exposição foi considerada involuntária, tanto na degradação ambiental como na energia nuclear.

Com relação à percepção de seu caráter devastador, avaliaram-se os quesitos voltados para o tempo de duração do efeito, controle do risco, exposição e medo. Assim foi considerado pelos entrevistados que o efeito do risco é mais rápido e incontrolável para a energia nuclear. Em ambos existem muitas pessoas expostas e os efeitos são considerados assustadores.

\subsubsection{Preocupação com o meio ambiente}

Os entrevistados foram questionados sobre sua preocupação com o meio ambiente (tempo e motivação).

Os questionários $n^{\circ} 63,73,80,84,88,94,97,104,126,178$ e 196, foram excluídos desta avaliação, pois estavam sem respostas. Portanto restaram 213 questionários que foram avaliados de acordo com o que se segue (TAB. 36).

TABELA 36 - Preocupação com o meio ambiente

\begin{tabular}{lcr}
\hline \multicolumn{3}{l}{ Preocupa-se com o meio ambiente } \\
\hline Sim & 208 & $97,65 \%$ \\
Não & 5 & $2,35 \%$ \\
\hline
\end{tabular}

\begin{tabular}{lrr}
\hline \multicolumn{3}{c}{ Há quanto tempo? } \\
\hline Mais de 10 anos & 101 & $47,42 \%$ \\
Menos de 10 anos & 51 & $23,94 \%$ \\
Menos de 5 anos & 50 & $23,47 \%$ \\
Menos de 1 ano & 6 & $2,82 \%$ \\
Não respondeu & 5 & $2,35 \%$ \\
\hline
\end{tabular}




\begin{tabular}{lrr}
\hline \multicolumn{3}{c}{ Motivação } \\
\hline Educação & 51 & $23,94 \%$ \\
Consumo consciente & 34 & $15,96 \%$ \\
Desastres naturais & 26 & $12,21 \%$ \\
Futuro & 21 & $9,86 \%$ \\
Mídia & 20 & $9,39 \%$ \\
Extinção & 17 & $7,98 \%$ \\
Degradação ambiental & 16 & $7,51 \%$ \\
Mudanças climáticas & 15 & $7,04 \%$ \\
Problemas ambientais & 15 & $7,04 \%$ \\
Informação & 9 & $4,23 \%$ \\
Poluição & 9 & $4,23 \%$ \\
Futuro dos filhos & 7 & $3,29 \%$ \\
Qualidade de vida & 3 & $1,41 \%$ \\
Bíblia / Deus & 2 & $0,94 \%$ \\
Maturidade & 2 & $0,94 \%$ \\
Profissão & 2 & $0,94 \%$ \\
Não respondeu & 9 & $4,23 \%$ \\
\hline
\end{tabular}

A maioria se preocupa com o meio ambiente há mais de 10 anos, apontando a educação como principal motivo para essa preocupação, levando a ações como o consumo consciente e a busca por qualidade de vida e um futuro melhor (TAB. 36).

\subsubsection{Preocupação com a energia nuclear}

Os entrevistados foram questionados sobre sua preocupação com a energia nuclear (tempo e motivação).

Os questionários $\mathrm{n}^{\circ} 63,73,80,84,88,94,97,178$ e 196, foram excluídos desta avaliação, pois estavam sem respostas. Portanto restaram 215 questionários que foram avaliados de acordo com o que se segue (TAB. 37).

TABELA 37 - Preocupação com a energia nuclear

\begin{tabular}{lrl}
\hline \multicolumn{3}{c}{ Há quanto tempo? } \\
\hline Igual antigamente & 83 & $38,60 \%$ \\
Maior do que antigamente & 70 & $32,56 \%$ \\
Menor do que antigamente & 38 & $17,67 \%$ \\
Não me preocupo & 24 & $11,16 \%$ \\
\hline
\end{tabular}


TABELA 38 - Motivação dos que se preocupam igual antigamente

\begin{tabular}{lcc}
\hline \multicolumn{3}{c}{ Igual antigamente } \\
\hline \multicolumn{1}{c}{ IDENTIFICADOR } & FREQUÊNCIA & $\mathbf{\%}$ \\
\hline Falta de informação & 21 & $9,77 \%$ \\
Não respondeu & 17 & $7,91 \%$ \\
Risco aceitável & 7 & $3,26 \%$ \\
Pouco utilizada & 6 & $2,79 \%$ \\
Conhecimento & 5 & $2,33 \%$ \\
Lixo & 4 & $1,86 \%$ \\
Riscos envolvidos & 4 & $1,86 \%$ \\
Bombas & 3 & $1,40 \%$ \\
Decisões políticas & 3 & $1,40 \%$ \\
Não respondeu & 17 & $7,91 \%$ \\
\hline
\end{tabular}

TABELA 39 - Motivação dos que se preocupam mais do que antigamente

\begin{tabular}{lcc}
\hline \multicolumn{3}{c}{ Maior do que antigamente } \\
\hline \multicolumn{1}{c}{ IDENTIFICADOR } & FREQUÊNCIA & $\%$ \\
\hline Acesso à informação & 10 & $4,65 \%$ \\
Lixo & 6 & $2,79 \%$ \\
Acidente & 5 & $2,33 \%$ \\
Uso iminente & 5 & $2,33 \%$ \\
Bombas & 4 & $1,86 \%$ \\
Decisões políticas & 4 & $1,86 \%$ \\
Fins bélicos & 4 & $1,86 \%$ \\
Impacto ambiental & 4 & $1,86 \%$ \\
Angra dos Reis & 3 & $1,40 \%$ \\
Riscos envolvidos & 3 & $1,40 \%$ \\
Não respondeu & 5 & $2,33 \%$ \\
\hline
\end{tabular}

TABELA 40 - Motivação dos que se preocupam menos do que antigamente

\begin{tabular}{lcc}
\hline \multicolumn{3}{c}{ Menor do que antigamente } \\
\hline \multicolumn{1}{c}{ IDENTIFICADOR } & FREQUÊNCIA & $\%$ \\
\hline Segurança & 11 & $5,12 \%$ \\
Conhecimento & 6 & $2,79 \%$ \\
Risco aceitável & 6 & $2,79 \%$ \\
Avanços tecnológicos & 5 & $2,33 \%$ \\
Lixo & 3 & $1,40 \%$ \\
Não respondeu & 3 & $1,40 \%$ \\
\hline
\end{tabular}

TABELA 41 - Motivação dos que não se preocupam

\begin{tabular}{lcc}
\hline \multicolumn{3}{c}{ Não me preocupo } \\
\hline \multicolumn{1}{c}{ IDENTIFICADOR } & FREQUÊNCIA & $\%$ \\
\hline Falta de informação & 7 & $3,26 \%$ \\
Risco aceitável & 5 & $2,33 \%$ \\
Falta de interesse & 3 & $1,40 \%$ \\
Não respondeu & 3 & $1,40 \%$ \\
\hline
\end{tabular}


A preocupação pode se dar pelo acesso à informação ou por falta de acesso à informação. Os resultados (TAB. 37 a 41) mostram que 9,77\% dos que afirmam que sua preocupação não mudou e 3,26\% dos que afirmam que não se preocupam, julgam a falta de informação como motivo, já 4,65\% que afirmam se preocuparem mais do que antigamente, apontam o acesso à informação como motivador para sua preocupação.

Os termos risco aceitável e o lixo produzido aparecem em diversas respostas, tanto entre os que se preocupam como entre os que dizem não se preocupar. Apesar do apontamento com a preocupação sobre o tratamento do lixo radioativo, o risco foi considerado aceitável diante dos benefícios percebidos.

Após a Segunda Guerra Mundial houve um aumento do interesse por assuntos relacionados à tecnologia e ciência, a tarefa de acompanhar, reproduzir e difundir o progresso tecnológico ficou a cargo dos meios de comunicação de massa, que geralmente são a única fonte de informações acessível à sociedade, e por vezes com pouco discernimento científico e imparcialidade, acaba por influenciar negativamente a opinião pública (Ponce, 2002).

\subsubsection{Pesquisa após o acidente com as usinas nucleares japonesas}

Em pesquisa realizada pela Worldwide Independent Network of Market Research (WIN) em parceria com o IBOPE Inteligência, no período de 21 de março a 10 de abril de 2011, sobre o efeito do acidente nuclear nas usinas de Fukushima na opinião pública de diversos países, incluindo o Brasil, mostrou o resultado apresentado na FIG. 33 (IBOPE, 2011). 


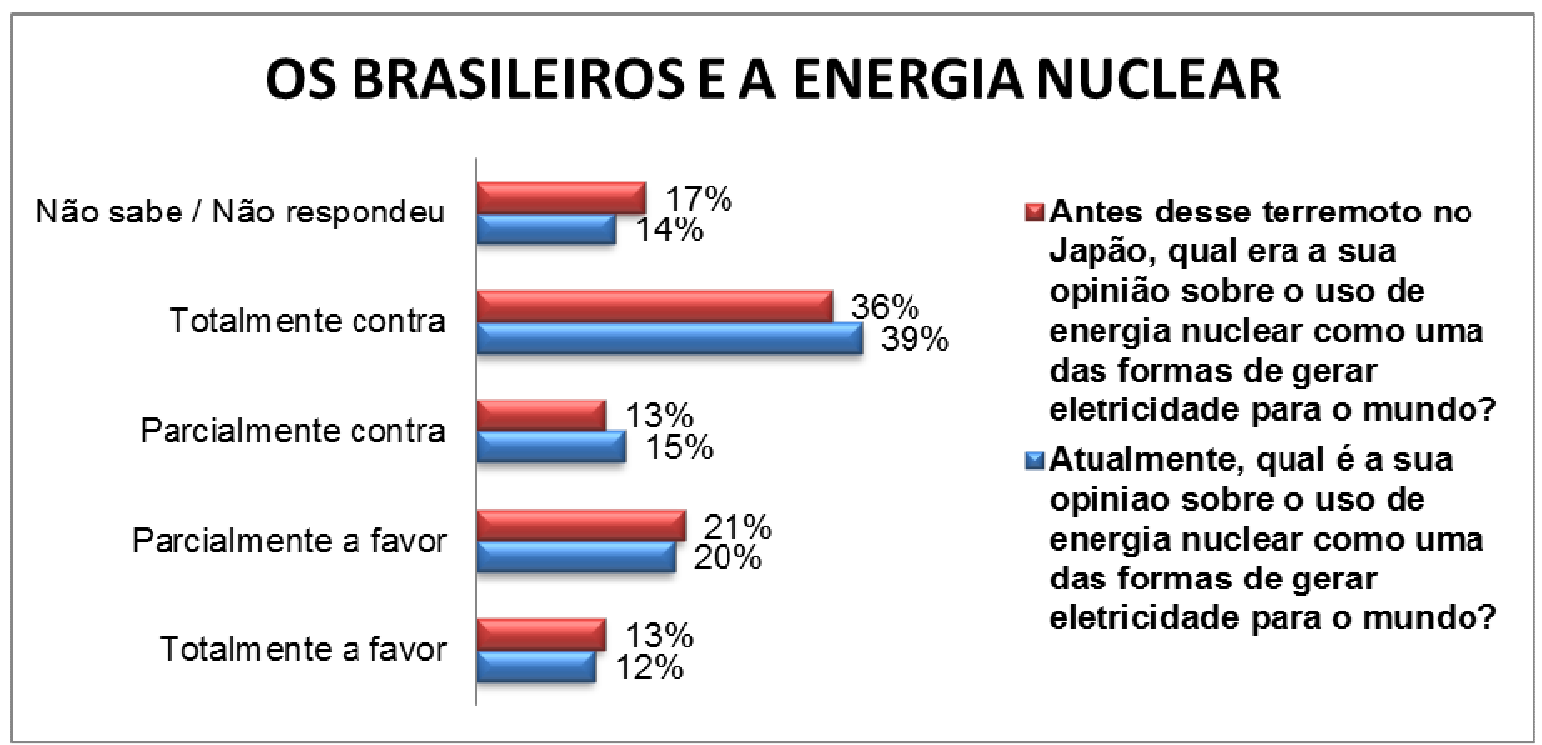

FIGURA 33 - Pesquisa de opinião sobre o uso da energia nuclear Fonte - IBOPE, 2011, com adaptações

Os resultados mostram uma coerência com o diagnóstico feito nesse trabalho, quando comparados com os dados da TAB. 37 e FIG. 31 e 32 . Isso evidenciou a existência de uma parcela da população que é esclarecida sobre o tema e que qualquer programa de incentivo à aceitação da energia nuclear pode ser construído sobre uma base de opinião já consolidada.

A pesquisa foi realizada em diversos países e, a surpresa veio do Japão, onde $40 \%$ continuam apoiando o uso da energia nuclear para produção de energia, mesmo com aumento no percentual dos que são contra em dezenove pontos percentuais, de $28 \%$ para $47 \%$ (TAB. 42). Outro fator importante é que o número de pessoas que alegam desconhecer o assunto diminuiu (FIG. 33). 0 esclarecimento decorrente da cobertura massiva do tema pela imprensa contribuiu para que a população ganhasse mais cultura na área e, com isso, se tornasse menos preconceituosa e mais esclarecida.

TABELA 42 - Pesquisa de opinião: países desfavoráveis ao uso da energia nuclear, antes e depois do acidente com as usinas nucleares japonesas

\begin{tabular}{lccc}
\hline & ANTES & DEPOIS & DIFERENÇA\% \\
\hline Média global & $\mathbf{3 2} \%$ & $\mathbf{4 3 \%}$ & $\mathbf{1 1 \%}$ \\
Brasil & $49 \%$ & $54 \%$ & $5 \%$ \\
Japão & $\mathbf{2 8 \%}$ & $47 \%$ & $19 \%$ \\
\hline
\end{tabular}

Fonte - IBOPE, 2011, com adaptações 
A pesquisa realizada (TAB. 42) apontou um aumento de $11 \%$ para a média global dos países que são desfavoráveis ao uso da energia nuclear para produção de energia. Especificamente o Japão apresentou um aumento de $19 \%$ e o Brasil de $5 \%$. 


\section{CONCLUSÃO}

Com base na análise dos dados obtidos pela pesquisa em campo, e considerando-se a teoria estudada, pode-se concluir que a percepção de risco relacionada às questões ambientais, especialmente às voltadas para temas, como o aquecimento global, tem sobressaído na opinião pública, superando a percepção de risco ligada à questão do uso da energia nuclear.

A memória social acerca dos riscos ambientais, decorrentes das degradações constantes, tem sobressaído ante os acidentes nucleares do passado, o que reforça o explicitado por Slovic et al (2004), de que os eventos frequentes são mais fáceis de lembrar do que os eventos menos frequentes, bem como as ocorrências prováveis são mais fáceis de imaginar do que as improváveis.

Neste ponto, o estudo demonstrou que, durante o período de realização da pesquisa, em 2010, os eventos e ocorrências ambientais são mais evidenciados, visto que os eventos e ocorrências de acidentes e tragédias nucleares estão arraigados ao passado, apesar de ainda presentes na memória social e apresentando riscos percebidos, não estão presente nas preocupações da população estudada.

$\mathrm{O}$ acidente com as usinas nucleares japonesas pode ter invertido essa percepção embora, a resistência dos reatores em uma situação tão adversa, como o terremoto de 8.9 graus na escala Richter, seguido de tsunamis, tenha ensejado a revisão do ponto de vista de pelo menos um ambientalista renomado (Monbiot, 2011).

Com isso, os dados obtidos na pesquisa, com a comparação entre as percepções de risco ambiental e nuclear mostrou que, mesmo tendo a lembrança dos acidentes e ataques nucleares, a maior preocupação dos estudantes estava relacionada com os riscos ambientais, decorrentes das constantes degradações ambientais.

Quando o perigo não é resultado de um evento natural, e sim da atividade do homem, a formação de grupos opositores é uma das maneiras de se 
lidar com o desconforto causado pela incerteza do futuro (Sjöberg e DrottzSjöberg, 1994).

Essa possível substituição da percepção do risco nuclear pelo risco ambiental, na atualidade, deve ser aproveitada, como um momento propício, para a educação e a comunicação do risco nuclear.

A comunicação científica do setor nuclear pode agir neste ponto, de maneira a mostrar ao público os benefícios e riscos envolvidos no uso da tecnologia nuclear para fins de geração de energia elétrica, buscando o apoio e a aceitação pública, para sua pesquisa e desenvolvimento no país.

"Comunicar ciência deixou de ser uma atitude restrita aos cientistas, pois transformou-se numa atividade imprescindível à manutenção do progresso científico e num direito do cidadão em saber como está sendo empregado o conhecimento no mundo em que habita." (Ponce, 2002, p. 8 e 9).

A importância dos fatores cognitivos na comunicação da informação pode ser assim explicada, visto que os valores são criados e assimilados ao longo do tempo da humanidade, marcando a relação das pessoas com o mundo.

A pesquisa mostrou que os estudantes de hoje, estão predispostos a compreender melhor novas tecnologias e apoiá-las, desde que tenham acesso a informações reais e verídicas.

É importante ressaltar que os estudantes, população desta pesquisa, podem ser os formadores de opinião do futuro, e que, portanto, um trabalho de divulgação científica com este público, pode trazer frutos importantes para o desenvolvimento do setor nuclear brasileiro. Visto que, quanto maior a percepção de risco, maior o ajustamento considerado necessário para trazer o risco para um nível aceitável (Slovic et al, 2004).

Neste momento se faz importante ressaltar que o último evento ambiental e nuclear ocorrido no Japão em março de 2011, pode influenciar a postura mundial diante das questões "tema" deste trabalho. Desta maneira, a percepção do público desta pesquisa pode ter sido influenciada e profundamente alterada com as notícias veiculadas nos últimos dias, podendo daqui a algum tempo se consolidar em novas posturas e atitudes, pois diante de grandes catástrofes toda a sociedade é obrigada a repensar e refletir sobre o futuro. 
Desta forma, notamos que a percepção de risco é construída com base nas vivências individuais e sociais, além de ser historicamente construída, estando, portanto em constante transformação.

Como apontado por Slovic (1992), um acidente em um reator nuclear pode ter imensas consequências sociais se for percebido pelo público como um prenúncio de novos acidentes possivelmente catastróficos.

Neste momento, para a gestão de risco, a preservação e a restauração da confiança devem ser prioridade em todos os países que pretendem continuar com seus programas nucleares. Sabendo que crise também é oportunidade, ficou evidente que após o acidente com as usinas nucleares japonesas, o nível de esclarecimento também aumentou, em decorrência de uma intensa cobertura jornalística. Se por um lado houve um acirramento das emoções, por outro houve um crescimento da razão, tornando a opção nuclear menos suscetível a abordagens demagógicas.

A porcentagem da população brasileira que aceita a energia nuclear, nesse estudo recorte da parcela com maior escolarização, possibilita vislumbrar programas de aceitação que podem partir com um grande número de formadores de opinião. Essa base consolidada é um facilitador inexistente há pouco tempo atrás. Ações que o IPEN desenvolve, tais como as visitas programadas às suas instalações, o "IPEN vai à escola", o Jornal Órbita, o espaço cultural e o vídeo institucional tem sido importantes na formação dessa base. 


\section{TRABALHOS FUTUROS}

- Comparar os dados obtidos até 2010 com outros de 2011 em diante que abranjam o acidente com as usinas nucleares japonesas;

- Realizar trabalhos semelhantes com objetivos direcionados para, após diagnóstico, elaborar programas de aceitação pública. Os objetos de avaliação podem ser: Reator Multipropósito Brasileiro (RMB), Laboratório de Geração Nucleoelétrica (Labgene), Repositório de Rejeitos Radioativos, novas usinas nucleares, estaleiro naval para submarino nuclear, entre outros. 


\section{APÊNDICE - Formulário aplicado na pesquisa de campo}

\section{Caro estudante}

Em primeiro lugar, agradecemos seu interesse em colaborar com esta pesquisa. Sabemos que seu tempo é precioso. Por isso, garantimos que esta pesquisa não levará mais que 10 minutos.

Esta coleta fará parte de uma pesquisa acadêmica, realizada com estudantes de graduação e pósgraduação, desta forma seus dados não serão analisados individualmente. Este questionário está dividido em quatro partes, na primeira delas, você responderá a algumas perguntas para que possamos comparar seu perfil com os demais participantes, na sequência você responderá a algumas questões gerais.

Desde já, muito obrigada!

Prof. Dr. Afonso Rodrigues de Aquino

Verônica Araujo Boemer - Mestranda da Universidade de São Paulo - USP

\section{$1^{a}$ parte: Perfil do entrevistado}

Idade: ( ) anos

Sexo: ( ) Masculino ( ) Feminino
Estado Civil: ( ) Solteiro
( ) Casado, com filho(s) ( ) Desquitado / divorciado / separado
( ) Viúvo
( ) Outros:

Está cursando:
( ) Graduação
( ) Mestrado
( ) Pós-doutorado
Curso / Área:
) Pós-graduação (especialização)
( ) Doutorado

A instituição em que estuda é:
( ) Pública
( ) Particular

Em qual cidade você estuda?

Caso deseje, indique o nome da Universidade:
Está
Empregado? ( ) Sim ( ) Não

Ramo de

Atividade:

\section{$2^{\mathrm{a}}$ parte: Figuras}

1. Nomeie as imagens apresentadas, conforme o que remete sua lembrança, depois indique o sentimento que a imagem lhe desperta: 

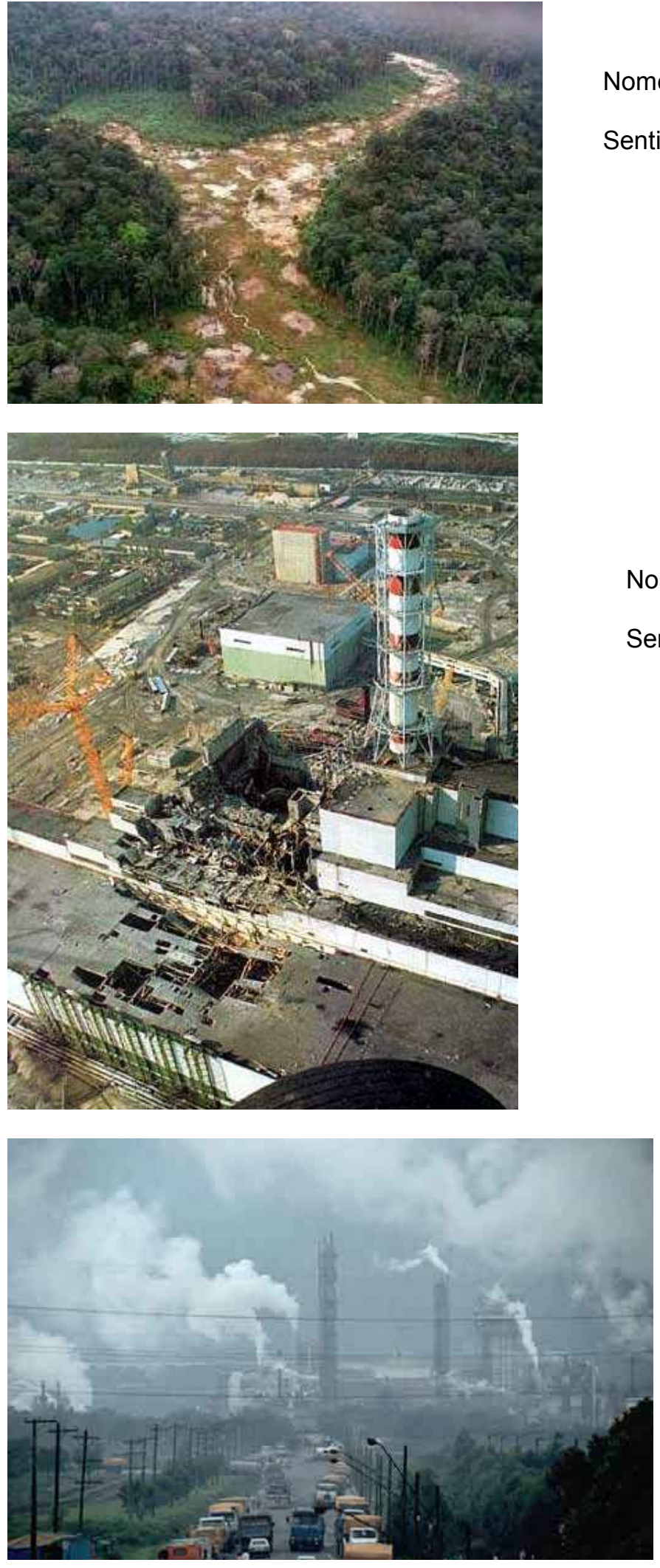

Nome:

Sentimento:

Nome:

Sentimento:

Nome:

Sentimento: 


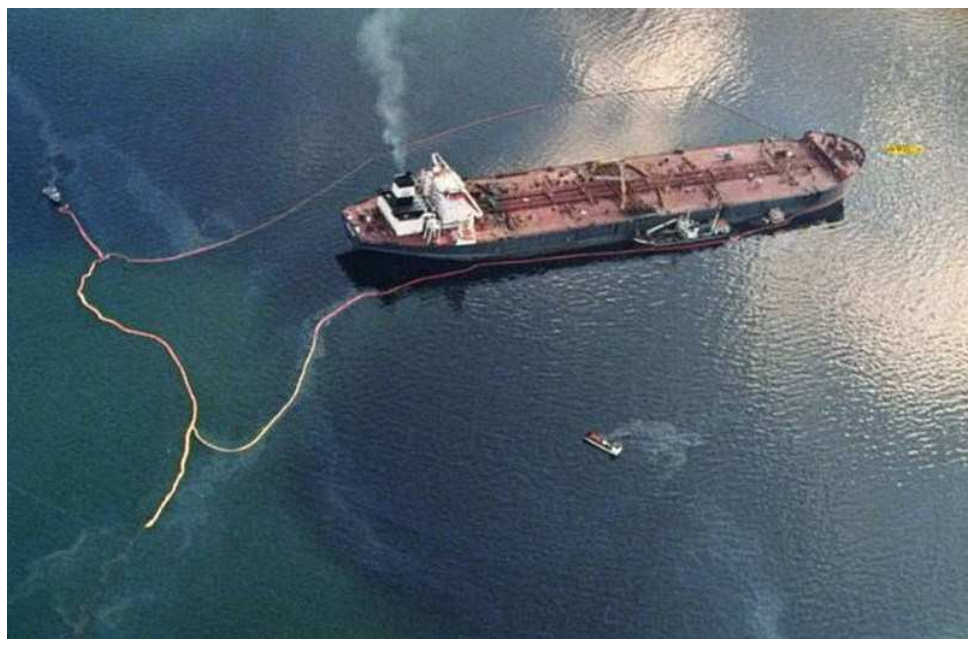

Nome:

Sentimento:

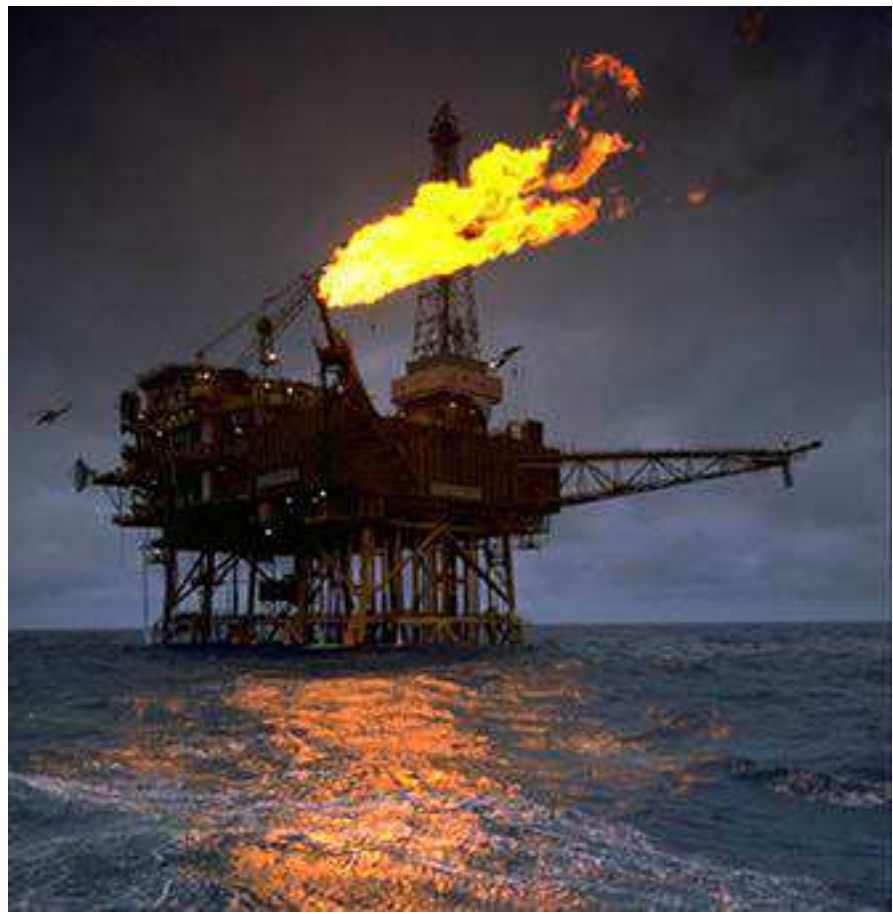

Nome:

Sentimento:

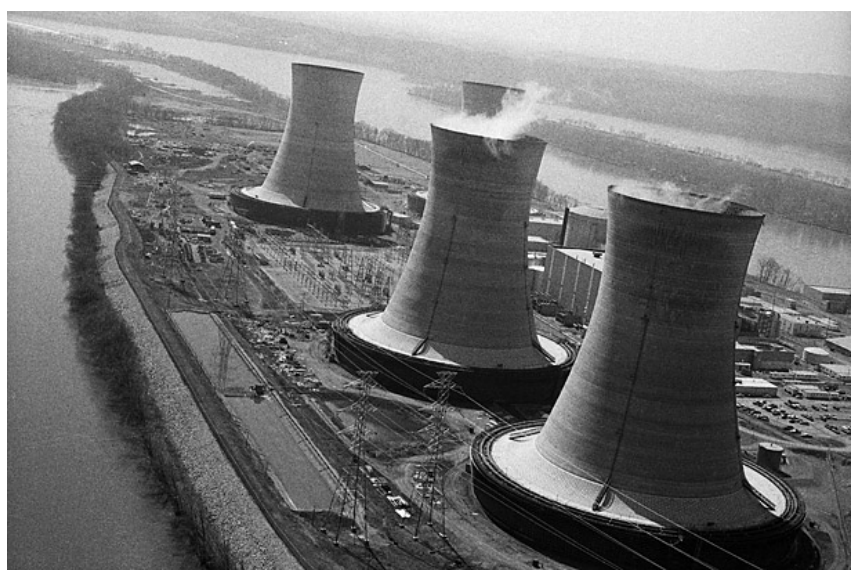

Nome:

Sentimento: 


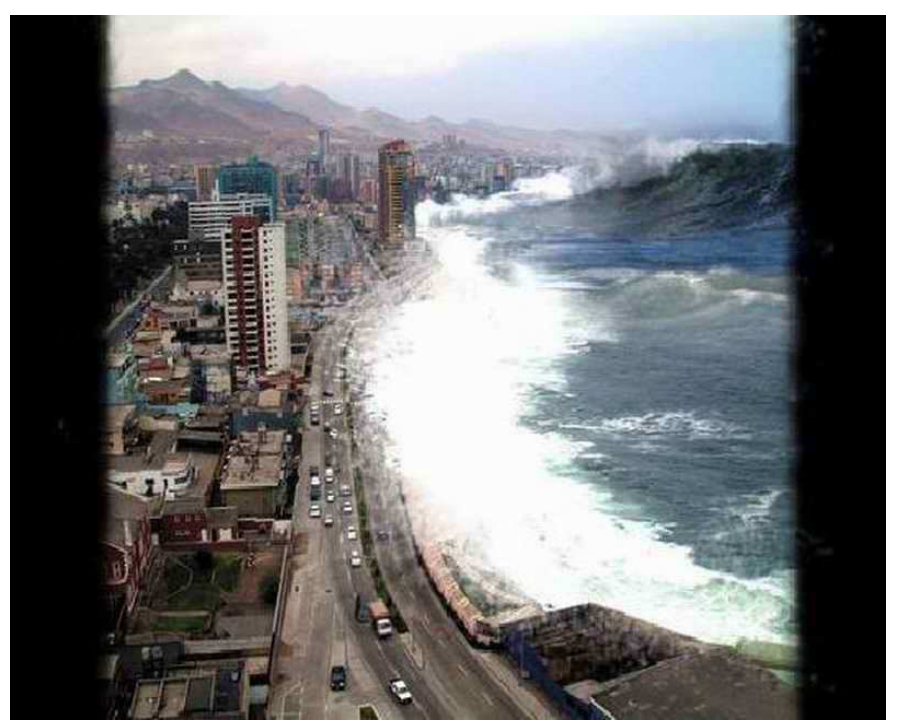

Nome:

Sentimento:

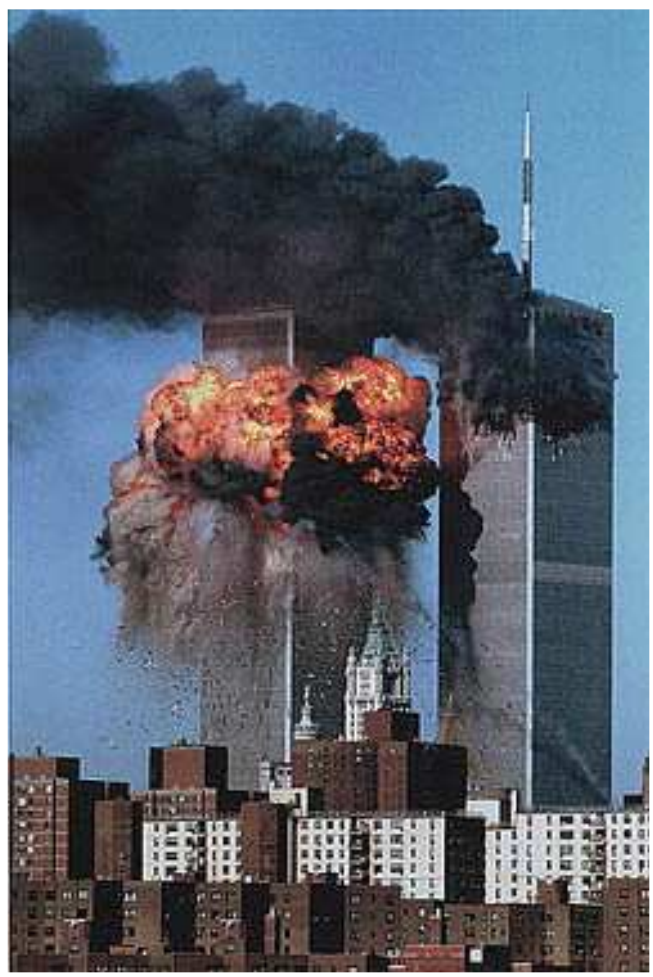

Nome:

Sentimento:

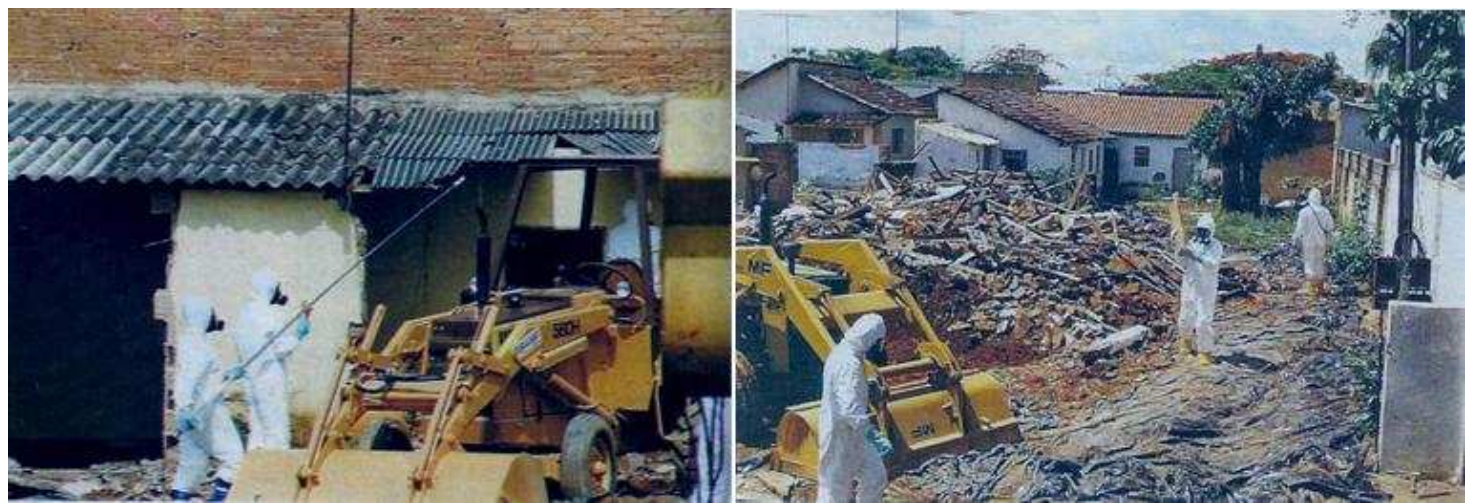

Nome:

Sentimento: 


\section{$3^{\mathrm{a}}$ parte: Escala}

1. Em uma escala de 1 a 10 (sem repetir as notas), sendo o 1 o menos perigoso e o $10 \mathrm{o}$ mais perigoso. Coloque em ordem de risco as seguintes atividades.

( ) Viagem de avião

( ) Fumar

( Emissão de fumaça (veículos automotivos)

( ) Colesterol

( ) Reator nuclear

( ) Destruição da camada de ozônio

( ) Desmatamento

( ) Poluição dos rios

( ) Hidroelétrica

( ) Efeito estufa

\section{$4^{\mathrm{a}}$ parte: Questionário}

1. O que the vem à mente quando se fala em energia nuclear?

2. Na lista abaixo indique os BENEFíCIOS (se houver) e os RISCOS (se houver), relacionados a cada item:

\begin{tabular}{|l|l|l|}
\hline & \multicolumn{1}{|c|}{ BENEFÍCIOS } & \multicolumn{1}{|c|}{ RISCOS } \\
\hline Hidroelétrica & & \\
\hline Veículos automotivos & & \\
\hline Indústria química & & \\
\hline Novos tratamentos médicos & & \\
\hline Termoelétrica novos & & \\
\hline $\begin{array}{l}\text { Desenvolvimento de } \\
\text { materiais }\end{array}$ & & \\
\hline Radioterapia & & \\
\hline $\begin{array}{l}\text { Soja transgênica } \\
\text { Reator nuclear de Angra dos } \\
\text { Reis }\end{array}$ & & \\
\hline
\end{tabular}

3. Pense no risco associado ao uso da energia nuclear, e classifique-o nas seguintes dimensões:

\begin{tabular}{|r|rrrrrrr|l|}
\hline Exposição ao risco é voluntária & 1 & 2 & 3 & 4 & 5 & 6 & 7 & Exposição ao risco é involuntária \\
\hline Tem efeito rápido & 1 & 2 & 3 & 4 & 5 & 6 & 7 & Tem efeito lento \\
\hline É conhecido das pessoas & 1 & 2 & 3 & 4 & 5 & 6 & 7 & É desconhecido das pessoas \\
\hline É conhecido para a ciência & 1 & 2 & 3 & 4 & 5 & 6 & 7 & É desconhecido para a ciência \\
\hline Risco é controlável & 1 & 2 & 3 & 4 & 5 & 6 & 7 & Risco é incontrolável \\
\hline É um risco novo & 1 & 2 & 3 & 4 & 5 & 6 & 7 & É um risco antigo \\
\hline É um risco assustador & 1 & 2 & 3 & 4 & 5 & 6 & 7 & É um risco pouco assustador \\
\hline Há muitas pessoas expostas & 1 & 2 & 3 & 4 & 5 & 6 & 7 & Há poucas pessoas expostas \\
\hline
\end{tabular}


4. O que lhe vem à mente quando se fala em degradação ambiental?

5. Pense no risco associado à degradação ambiental, e classifique-o nas seguintes dimensões:

\begin{tabular}{|c|c|c|c|c|c|c|c|c|}
\hline Exposição ao risco é voluntária & 1 & 2 & 3 & 4 & $\mathbf{5}$ & 6 & 7 & Exposição ao risco é involuntária \\
\hline Tem efeito rápido & 1 & 2 & 3 & 4 & 5 & 6 & 7 & Tem efeito lento \\
\hline É conhecido das pessoas & 1 & 2 & 3 & 4 & 5 & 6 & 7 & É desconhecido das pessoas \\
\hline É conhecido para a ciência & 1 & 2 & 3 & 4 & 5 & 6 & 7 & É desconhecido para a ciência \\
\hline Risco é controlável & 1 & 2 & 3 & 4 & 5 & 6 & 7 & Risco é incontrolável \\
\hline É um risco novo & 1 & 2 & 3 & 4 & 5 & 6 & 7 & É um risco antigo \\
\hline É um risco assustador & 1 & 2 & 3 & 4 & 5 & 6 & 7 & É um risco pouco assustador \\
\hline Há muitas pessoas expostas & 1 & 2 & 3 & 4 & 5 & 6 & 7 & Há poucas pessoas expostas \\
\hline
\end{tabular}

6. Você se preocupar com o meio ambiente?

$$
\text { ( ) Sim ( ) Não }
$$

7. Caso sua resposta seja sim. Há quanto tempo?
( ) Menos de 1 ano
( ) Menos de 10 anos
( ) Menos de 5 anos
( ) Mais de 10 anos

8. O que fez você se preocupar com o meio ambiente?

9. Hoje em dia a sua preocupação com a energia nuclear é:
( ) Maior do que antigamente
( ) Igual antigamente
( ) Menor do que antigamente
( ) Não me preocupo

10. Por quê?

Obrigada pela sua participação.

Caso queira mais informações sobre este trabalho, entre em contato com a pesquisadora pelo email: veronica.boemer@usp.br

Verônica Araujo Boemer

Mestranda do Instituto de Pesquisas Energéticas e Nucleares - IPEN

Universidade de São Paulo - USP 


\section{REFERÊNCIAS BIBLIOGRÁFICAS}

AVILA, A. M. de. Uma síntese do quarto relatório do IPCC. Revista Multiciência. Campinas, p. 163-168, maio 2007. Disponível em:

<http://www.multiciencia.unicamp.br/artigos_08/r01_8.pdf>. Acesso em: 12 jan. 2011.

BERNSTEIN, P. L. Desafio aos deuses: a fascinante história do risco. Rio de Janeiro: Elsevier, 1997. Título original: Against the gods.

BRASIL. Constituição. Brasília, DF: Senado Federal, 1988.

BRASIL. Ministério de Minas e Energia. Secretaria de Planejamento e Desenvolvimento Energético. Empresa de Pesquisa Energética. Plano nacional de energia 2030. Brasília, DF, 2007. Disponível em:

$<$ http://www.mme.gov.br/mme/galerias/arquivos/publicacoes/pne_2030/PlanoNaci onalDeEnergia2030.pdf>. Acesso em: 12 dez. 2009.

CAMARGO, G. O fogo dos deuses: uma história da energia nuclear, Pandora 600 a.C.-1970. Rio de Janeiro: Contraponto, 2006.

CHAVES, E. G. Impacto psico-social do acidente com o Césio-137 na sociedade brasileira. Goiânia: UFG, 1993.

CORRAL-VERDUGO, V. Psicologia ambiental: objeto, "realidade" sócio-físicas e visões culturais de interação ambiente-comportamento. Psicologia USP, São Paulo, v. 16, n. 1-2, p.71-87, 2005. Disponível em:

$<$ http://www.scielo.br/scielo.php?script=sci_arttext\&pid=S0103-

65642005000100009\&Ing=en\&nrm=iso>. Acesso em: 11 mar. 2008.

DELLA ROCCA, F. F. A percepção de risco como subsídio para os processos de gerenciamento ambiental. 2002. Tese (Doutorado) - Instituto de Pesquisas Energéticas e Nucleares, São Paulo.

FISCHHOFF, B.; SLOVIC, P.; LICHTENSTEIN, S.; READ, S.; COMBS, B. How safe is safe enough? A psychometric study of attitudes toward technological risks and benefits. In: SLOVIC, P. The perception of risk. London: Earthscan, 2004. p. 80-103. (Risk, society and policy series).

FREIRE-MAIA, A. Riscos nucleares e outros riscos: avaliação e aceitabilidade. Interciencia: revista de ciencias y tecnología de América, Caracas, v. 22, n. 5, p. 264-268, 1997. Disponível em: <http://www.interciencia.org/v22_05/ensayo.html>. Acesso em: 26 fev. 2009.

GIL, A. C. Métodos e técnicas de pesquisa social. São Paulo: Atlas, 2007. 
GUILAM, M. C. R. O conceito de risco: sua utilização pela epidemiologia, engenharia e ciências sociais. In: Estudo sobre Tecnobiociencias e Risco na Sociedade contemporânea. [S.I.]: Fiocruz,1996. Disponível em:

<http://www4.ensp.fiocruz.br/projetos/esterisco/maryfim1.htm>. Acesso em: 23 mar. 2009.

GUIMARÃES, L. dos S. Síntese de doutrina de segurança para projeto e operação de submarinos nucleares. 1999. Tese (Doutorado) - Escola Politécnica da Universidade de São Paulo, São Paulo.

HAWKES, N.; LEAN, G.; LEIGH, D.; MCKIE, R.; PRINGLE, P.; WILSON, A. Chernobyl: o fim do sonho nuclear. Tradução de Celina Cardim Cavalcante e Renato S. Beninatto. Rio de Janeiro: José Olympio, 1986. Título original: The worst accident in the world.

IBOPE. 57\% dos brasileiros temem incidente nuclear no Brasil. 19 abr. 2011. Disponível em:

$<$ http://www.ibope.com.br/calandraWeb/servlet/CalandraRedirect?temp=5\&proj=P ortallBOPE\&pub $=T \& d b=$ caldb\&comp $=\mid B O P E+$ Inteligência\&docid=57A5326CA700 959D8325787700483750>. Acesso em: 20 abr. 2011.

INSTITUTO BRASILEIRO DE GEOGRAFIA E ESTATÍSTICA - IBGE. População residente, por situação do domicilio - Brasil - 1940/2000. In:

Características da população. Disponível em:

<http://www.ibge.gov.br/ibgeteen/pesquisas/demograficas.html>. Acesso em: 27 maio 2008.

INTERNATIONAL ATOMIC ENERGY AGENCY - IAEA. Fukushima nuclear accident update log. Vienna, 2011. Disponível em:

<http://www.iaea.org/newscenter/news/tsunamiupdate01.html>. Acesso em: 15 mar. 2011.

JUNIOR RIBEIRO, J. A. R. Um estudo simplificado da percepção pública dos benefícios e riscos de centrais termonucleares. 2007. Dissertação (Mestrado) - Instituto de Pesquisas Energéticas e Nucleares, São Paulo.

KASPERSON, R. E.; RENN, O.; SLOVIC, P.; BROWN, H. S.; EMEL, J.; GOBLE, R.; KASPERSON, J. X.; RATICK, S. The social amplification of risk: a conceptual framework. In: SLOVIC, P. The perception of risk. London: Earthscan, 2004. p. 232-245. (Risk, society and policy series).

LIMA, M. L. P. de. Tragédia, risco e controlo: uma releitura psico-social dos testemunhos do terramoto de 1755. Análise Social, Lisboa, v. 43, n. 186, p. 728, 2008. Disponível em:

<http://www.scielo.oces.mctes.pt/pdf/aso/n186/n186a02.pdf>. Acesso em: 08 dez. 2010. 
MATTHES, F.; ROSENKRANZ, G.; BERMANN, C. (Org.). A energia nuclear em debate: Mitos, realidades e mudanças climáticas. Tradução de David Hathaway. [S.I.]: Fundação Heinrich Boell, [s.d.].

MOLAK, V. Fundamentals of risk analysis and risk management. Boca Raton: CRC Press, 1997.

MONBIOT, G. Fukushima fez de mim um partidário das usinas nucleares. Folha de São Paulo, São Paulo, 23 mar. 2011. Caderno 1, p. A15. Disponível em: <http://acervo.folha.com.br/fsp/2011/3/23/2>. Acesso em: 20 abr. 2011.

NASCIMENTO, K. Sustentabilidade, o enigma que ainda ronda as nações. Brasil Sempre=Brazil Forever . Rio de Janeiro, ano 8, n. 30, p. 14-21, 2007.

PONCE, I. Lugar de paradoxos: pelos caminhos discursivos do setor nuclear. 2002. Dissertação (Mestrado) - Universidade Federal de Pernambuco, Recife.

POPULATION Reference Bureau. World population growth, 1950-2050.

Disponível em:

$<$ http://www.prb.org/Educators/TeachersGuides/HumanPopulation/PopulationGro wth.aspx>. Acesso em: 13 jul. 2011.

PORTO, M. S. P. de L. Energia nuclear como fator de integração da América Latina. In: ENCUENTRO HACIA EL CONGRESSO ANFICTIONICO DE PANAMÁ, 2., 1998, Panama. Anales... Panama: [s.n.], 1988. Não paginado.

REZENDE, C. B.; COELHO, M. C. Antropologia das emoções. Rio de Janeiro: Editora FGV, 2010.

RODRIGUES MILORD, D.; DEL CASTILIO, P.; AGUILAR GARDUNO, C. Glosario de términos en salud ambiental: com especial énfasis en los efectos em la salud relacionados con las sustancias químicas. México: Metepec, 1995. Disponível em:

<http://www.crid.or.cr/digitalizacion/pdf/spa/doc10696/doc10696.htm>. Acesso em: 08 ago. 2010.

RODRIGUES, F.; FIGUEIREDO, M.; LIMA, L. Percepção de risco das alterações climáticas globais em ilhas: a percepção dos terceiros no arquipélago dos AçoresPortugal. In: CONGRESSO DE DESENVOLVIMENTO DE CABO VERDE, REDES E DESENVOLVIMENTO REGIONAL, 1., 2009, Cabo Verde. Anais eletrônicos... Cabo Verde: UniPiaget, 2009. p. 3416-3427. Disponível em: <http://www.apdr.pt/congresso/2009/pdf/Sess\%C3\%A30\%2035/35A.pdf>. Acesso em: 15 nov. 2009.

SÃO PAULO (Estado). Secretaria do Meio Ambiente. Gases de efeito estufa e fontes de emissão. Proclima: programa estadual de mudanças climáticas. Disponível em:

<http://homologa.ambiente.sp.gov.br/proclima/efeito_estufa/gases_fontes.asp>. Acesso em: 27 maio 2008. 
SÃO PAULO (Estado). Secretaria do Meio Ambiente. Tratados e organizações internacionais em matéria de meio ambiente. São Paulo: SMA, 1997.

(Entendendo o meio ambiente, v.1).

SJÖBERG, L.; DROTTZ-SJÖBERG, Britt-M., Risk Perception. In:

INTERNATIONAL CONFERENCE ON RADIATION AND SOCIETY:

COMPREHENDING RADIATION RISK, Aug. 24-28, 1994, Paris. Proceedings... Vienna: IAEA, 1994. v. 1, p. 29-60. (Proceedings series).

SLOVIC, P. Perception of risk and the future of nuclear power. In: ANNUAL INTERNATIONAL SCIENTIFIC FORUM ON ENERGY: MAKING THE MARKET RIGHT FOR THE EFFICIENT USE OF ENERGY, 15. Oct. 29-31, 1991, Washington. DC. Proceedings... Commack, NY: Nova Science Publ, 1992. p.151-159.

SLOVIC, P. Perception of risk. In: SLOVIC, P. The perception of risk. London: Earthscan, 2004. p. 220-231. (Risk, society and policy series).

SLOVIC, P.; FISCHHOFF, B.; LICHTENSTEIN, S. Facts and fears: understanding perceived risk. In: SLOVIC, P. The perception of risk. London: Earthscan, 2004. p. 137-153. (Risk, society and policy series).

TASSARA, E. T. de O.; RABINOVICH, E. P.; GUEDES, M. do C. (org.). Psicologia e ambiente. São Paulo: Educ, 2004.

WILDE, G. J. S. O limite aceitável de risco: uma nova psicologia de segurança e saúde: o que funciona? O que não funciona? E por quê? Tradução de Reinier Johannes Antonius Rozestraten. São Paulo: Casa do Psicólogo, 2005. Título original: Target risk 2: a new psychology of safety and healt: what doesn't? and why. 